\title{
Review on Nanomaterial-Based Melamine Detection
}

\author{
Muthaiah Shellaiah ${ }^{1} \mathbb{D}$ and Kien Wen Sun ${ }^{1,2, *}$ \\ 1 Department of Applied Chemistry, National Chiao Tung University, Hsinchu 30010, Taiwan; \\ muthaiah1981@nctu.edu.tw \\ 2 Department of Electronics Engineering, National Chiao Tung University, Hsinchu 30010, Taiwan \\ * Correspondence: kwsun@mail.nctu.edu.tw
}

Received: 27 November 2018; Accepted: 15 February 2019; Published: 20 February 2019

check for updates

\begin{abstract}
Illegal adulteration of milk products by melamine and its analogs has become a threat to the world. In 2008, the misuse of melamine with infant formula caused serious effects on babies of China. Thereafter, the government of China and the US Food and Drug Administration (FDA) limited the use of melamine of $1 \mathrm{mg} / \mathrm{kg}$ for infant formula and $2.5 \mathrm{mg} / \mathrm{kg}$ for other dairy products. Similarly, the World Health Organization (WHO) has also limited the daily intake of melamine of $0.2 \mathrm{mg} / \mathrm{kg}$ body weight per day. Many sensory schemes have been proposed by the scientists for carrying out screening on melamine poisoning. Among them, nanomaterial-based sensing techniques are very promising in terms of real-time applicability. These materials uncover and quantify the melamine by means of diverse mechanisms, such as fluorescence resonance energy transfer (FRET), aggregation, inner filter effect, surface-enhanced Raman scattering (SERS), and self-assembly, etc. Nanomaterials used for the melamine determination include carbon dots, quantum dots, nanocomposites, nanocrystals, nanoclusters, nanoparticles, nanorods, nanowires, and nanotubes. In this review, we summarize and comment on the melamine sensing abilities of these nanomaterials for their suitability and future research directions.
\end{abstract}

Keywords: food poisoning; melamine; milk products; nanomaterials; aggregation; nanodots and nanoparticles; composite materials; electrochemical detection; surface-enhanced Raman scattering; colorimetric recognition; fluorescent sensors; inner filter effect; fluorescence resonance energy transfer

\section{Introduction}

Recently, food safety has become a major issue due to the increase of occurrences of food poisoning [1-3]. For example, illegal adulteration of toxic materials, such as clenbuterol in meat and melamine in dairy product, leads to food poisoning and severe health problems [4-10]. In this light, melamine has been a well-known additive-with $66 \%$ nitrogen content—and is still utilized in the production of many plastics, adhesives, glues, fertilizers, plywoods, cements, cleansers, and retardant paints [11-15]. It has been illegally consumed in many dairy products due to its low toxicity, and hence leads to many health problems. Even though melamine is a low-toxic material, with a high concentration it may cause renal pathology and death of infants. Moreover, melamine can be hydrolysed to cyanuric acid in vitro, which forms an insoluble melamine-cyanurate complex and causes the formation of kidney stones and renal failure by obstruction [16-18].

On this track, several food poisoning incidents have signalled the need for control over illegal use of melamine. For instance, incidence of illness and death of pet animals was reported in North America in 2007 due to the formation of melamine-cyanurate crystals in the kidneys [19]. Similarly, nearly 300,000 infants were affected by an infant formula—contaminated with melamine—resulting in six deaths in 2008 [20]. The government of China limited the use of melamine of $1 \mathrm{mg} / \mathrm{kg}$ for infant formula and $2.5 \mathrm{mg} / \mathrm{kg}$ for other dairy products since then [21]. Subsequently, the World Health 
Organization (WHO) also fixed the daily intake limit of melamine to $0.2 \mathrm{mg} / \mathrm{kg}$ body weight per day [22], whereas the US Food and Drug Administration (FDA) promulgated the allowed limit of melamine of $1 \mathrm{mg} / \mathrm{kg}$ in infant formula and $2.5 \mathrm{mg} / \mathrm{kg}$ for other dairy products [23].

To rectify the harmful effects of melamine, diverse analytical tactics have been developed towards its detection in dairy and food items. Among them, the chromatographic techniques, such as high-performance liquid chromatography (HPLC), ultra-performance liquid chromatography/tandem mass spectrometry (UPLC/MS/MS), and gas chromatography/mass spectrometry (GC/MS) [24-33], produced convincing results and proved their suitability for melamine determination. However, apart from exceptional sensitivity and precision, these chromatographic and mass spectral methods are time consuming with high operating cost and requires skilled operators. Moreover, sample preparations for these chromatographic techniques are difficult, therefore they do not meet the requirement of on-site applicability. Hence, the development of profitable and easily synthesizable/fabricable melamine recognition probes with real-time applicability becomes essential. Such demand has been witnessed by the publications on the melamine detecting probes as presented in Figure 1. The rapid increase in publication numbers from 2009 to 2018 demonstrates the importance of melamine identification in dairy products worldwide. Among these probes, nanomaterial-based melamine sensors are highly regarded due to their potential in food and related products. Hence, an overall review on nanomaterial-based melamine sensors is required to direct upcoming novel designs towards a highly efficient determination of melamine.

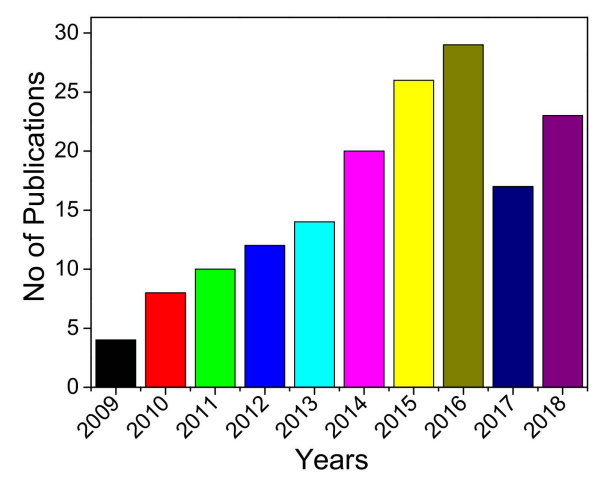

Figure 1. Numbers of publications on melamine sensors from 2009 to 2018 (adopted from Institute for Scientific Information (ISI) Web of Knowledge).

In this review, we survey and assess the nanomaterials-based melamine assays, especially covering reports on carbon dots, semiconductor quantum dots, nano-assemblies, nanoclusters, diverse nanocomposites, nanocrystals, nanoparticles, nanorods, and nanotubes, as well as other nanostructures, as illustrated in Figure 2.

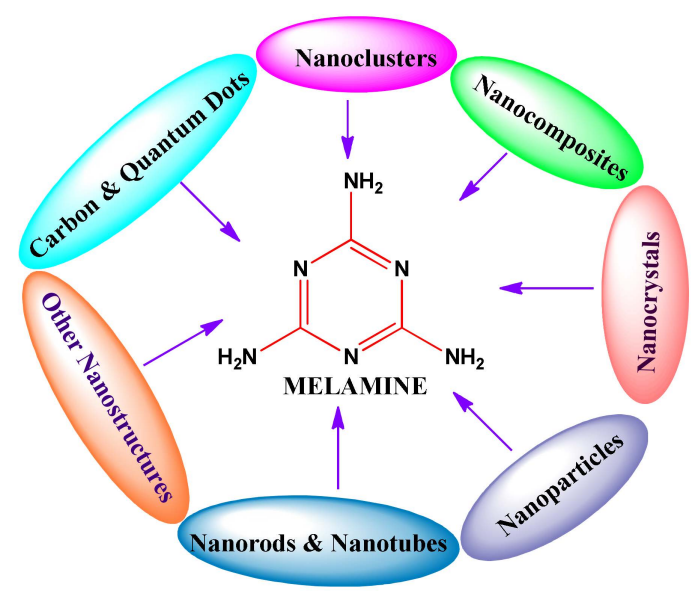

Figure 2. Schematic illustration of nanomaterial-based melamine determination. 


\section{Carbon and Quantum Dots for Melamine Detection}

Due to their nano size (usually less than $10 \mathrm{~nm}$ ), carbon dots (C-dots) have been utilized in numerous research fields. The unique properties in luminescence, biocompatibility, and low toxicity of C-dots allow them to be applied in a variety of analyte detections [34]. For example, Lei et al. utilized C-dots for the fluorescent "turn-on" determination of melamine via anti-quenching ability of $\mathrm{Hg}^{2+}$ to $\mathrm{C}$-dots [35]. Wherein, the melamine tends to coordinate with $\mathrm{Hg}^{2+}$ through multi-nitrogen heterocyclic ring, which further leads to the anti-quenching and results to the fluorescence recovery of C-dots. Their work demonstrated a linear range from 1 to $20 \mu \mathrm{M}$ ( $\mu \mathrm{M}=$ micromole) and exhibited a detection limit (LOD) of $0.3 \mu \mathrm{M}$. Moreover, the obtained analytical recoveries in milk samples support reliability for real-time applications. Similar to the C-dot studies, Zhu and co-workers employed graphene quantum dots (GQDs) towards the selective assay of melamine in the presence of $\mathrm{Hg}^{2+}$ ions [36]. In contrast to the C-dots, the melamine addition to GQDs in the presence of $\mathrm{Hg}^{2+}$ ions showed emission quenching rather than enhancement via charge transfer mechanism as shown in Figure 3. The above work was authenticated by recoveries in milk samples with linear regression range between 0.15 to $20 \mu \mathrm{M}$ and a LOD of $0.12 \mu \mathrm{M}$. Therefore, this method can be applied for melamine detection in real samples.

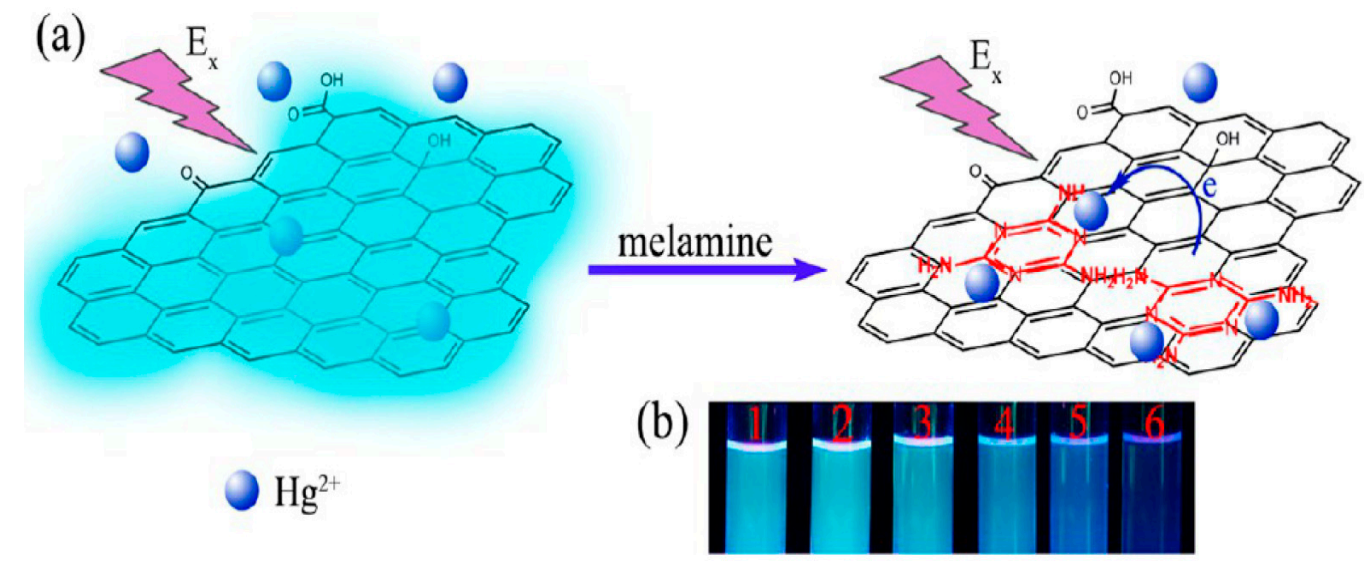

Figure 3. (a) Schematic illustration of melamine detection based on Fluorescence (FL) quenching of graphene quantum dots (GQDs) through charge transfer. (b) Optical photos of solutions of GQDs (Vial 1) and GQDs in the presence of melamine (Vial 2) or $\mathrm{Hg}^{2+}$ (Vial 3), and of GQDs- $\mathrm{Hg}^{2+}$ in the presence of $0.2,0.8,2.0 \mathrm{ppm}$ melamine for Vials 4, 5, 6, respectively, taken under a $365 \mathrm{~nm}$ UV lamp (reproduced with permission from Reference [36]).

In this light, CdTe quantum dots were employed in the assay of melamine as noted next. In 2012, Zhang et al. publicized the use of thioglycolic acid-capped CdTe quantum dots (TGA-CdTe QDs) towards melamine detection [37]. The quantum dots were synthesized via microwave-assisted method, which discriminate the melamine via fluorescence quenching response. From the calibration plots, the linear regression of melamine detection was recognized as 79.2-793 $\mu \mathrm{M}$ with a LOD of $317 \mathrm{nM}$ $(\mathrm{nM}=$ nanomole). This method shows high precision and accuracy during the melamine recognition in raw milk. Following the above work, Li and co-workers evaluated the TGA-CdTe QDs further towards the determination of melamine [38]. The estimated linearity of melamine ranged from $10 \mathrm{pM}$ to $10 \mu \mathrm{M}$ (pM = picomole) with a LOD of $5 \mathrm{pM}$. This method can be used to distinguish the melamine in alkaline aqueous solution as well.

Beside the aforementioned reports, molecularly-imprinted polymer (MIP) -capped CdTe quantum dots (MIP-CdTe QDs) were employed in the sensing of clenbuterol and melamine by Huy and co-workers [39]. The MIP-CdTe QDs were synthesized by radical polymerization process, which showed the luminescence quenching during the discovery of melamine. The linearity of melamine assay lies between 2.0-35 $\mu \mathrm{M}$ with a LOD of $0.6 \mu \mathrm{M}$. Notably, melamine in milk samples displayed more than $90 \%$ recovery. In a similar fashion, $\mathrm{Xu}$ and co-workers reported the molecularly-imprinted 
CdTe QDs for ratiometric discrimination of melamine [40]. As shown in Figure 4, these MIP@CdTe QDs were synthesized in a single step and then utilized in ratiometric identification of melamine. The linear regression of melamine assay ranged from 100 to $800 \mathrm{nM}$ with a LOD of $38 \mathrm{nM}$ was reported. The luminescence recoveries in milk samples were established as $92 \sim 101 \%$. This work can be used as a convenient, rapid, reliable and practical method for sensitive and selective fluorescence-based assay of melamine. However, the practicality of this study still needs to be further enhanced either by suitable modification or with combinations of other instruments

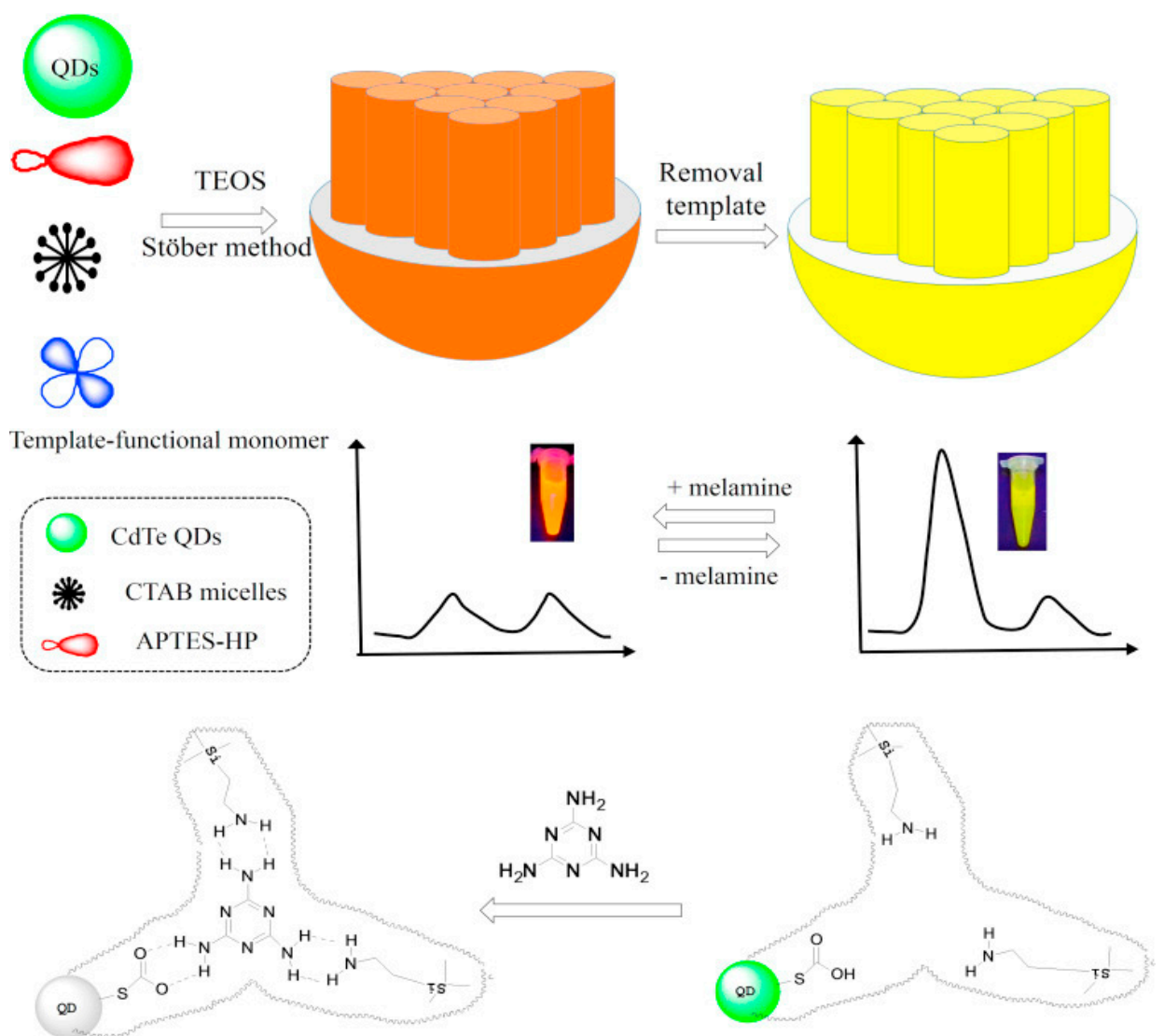

Figure 4. Schematic illustration for the one pot preparation of mesoporous structured ratiometric fluorescence of molecularly-imprinted polymers (MIPs) probe (reproduced with permission from Reference [40]).

At a later time, Zhang et al. presented a ratiometric fluorescent probe for visual detection of melamine (MEL) in milk samples [41]. The CdTe QDs with red emission were embedded within silica microspheres, and then the green emitting QDs were coated over silica microsphere surface as a shell. In addition, a molecularly-imprinted polymer (MIP) with binding site was placed on the shell for melamine recognition. During the melamine sensing the red-green fluorescence transformed into purely red via quenching of green emission due to the hydrogen bond interaction. The probe demonstrated a linearity between $396 \mathrm{nM}-7.93 \mu \mathrm{M}$ with a LOD of $103 \mathrm{nM}$. It also demonstrates the real-time applicability in milk samples and reveals the recoveries between 94.1 98.7\% with 3.6-5.1\% relative standard deviations (RSDs).

Cadmium and zinc sulfide quantum dots (CdS QDs and ZnS QDs) have also been used for melamine determination as described below. In 2012, Wang et al. established the fluorescent "turn-on" assay of melamine by thioglycolic acid-capped CdS quantum dots (TGA-CdS QDs) as illustrated in Figure 5 [42]. 


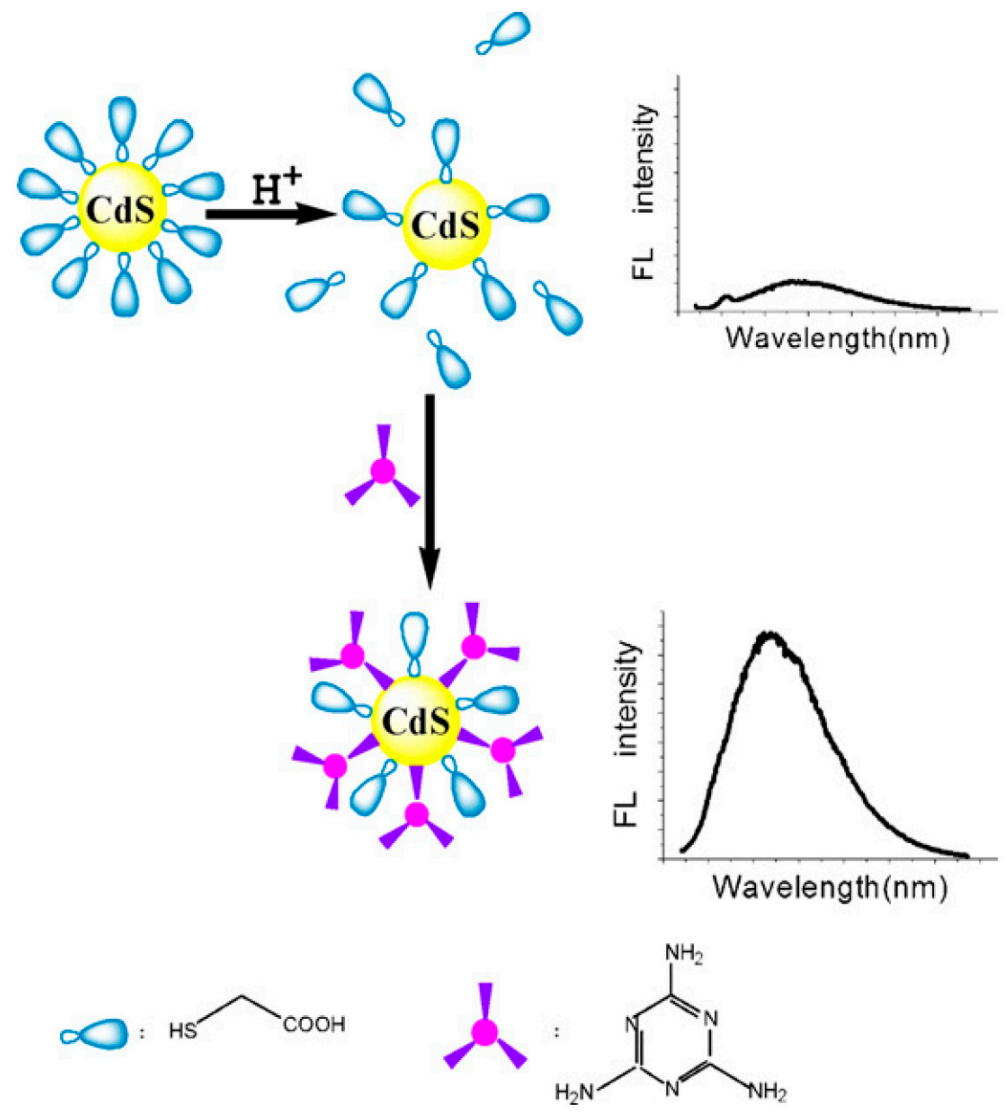

Figure 5. Scheme illustrating the interaction of melamine (MA) with thioglycolic acid (TGA) -capped cadmium sulfide quantum dots (CdS QDs) (reproduced with permission from Reference [42]).

Melamine was linearly identified between $2 \mathrm{nM}-50 \mu \mathrm{M}$ with an LOD of $1 \mathrm{nM}$ under optimum conditions. This method is proposed as a highly sensitive and low-cost technique for melamine recognition in milk samples. Similar to the above proposal, the inner filter effect of gold nanoparticles on the fluorescence of CdS QDs was addressed in the detection of melamine in raw milk samples [43]. For this evaluation, the L-Cysteine-capped CdS QDs (L-Cys-CdS QDs) in the presence of citrate-stabilized Au NPs were utilized by Cao and co-workers to exhibit a linear regression between $396 \mathrm{nM}-2.8 \mu \mathrm{M}$ with a LOD of $135 \mathrm{nM}$. Apart from mild complications, this method can be employed towards rapid screening of melamine in milk products.

The water soluble europium $\left(\mathrm{Eu}^{3+}\right)$ doped $\mathrm{ZnS}$ quantum dots towards the detection of melamine in milk samples and infant formula at room temperature were exploited by Gong et al. [44]. The room temperature phosphorescence (RTP) of Eu(III)-ZnS QDs was quenched during the recognition process. The phosphorescence intensity at $\lambda_{\mathrm{ex}}=290 \mathrm{~nm}$ diminished linearly between $39.6 \mathrm{nM}-3.96 \mu \mathrm{M}$ with a LOD of $9.67 \mathrm{nM}$ at $\mathrm{pH}$ 7.4. This technique was later applied in milk samples and displayed recoveries between $96 \sim 103 \%$ with a RSD of $1.2 \%$. Demirhan and co-workers also proposed the RTP-based determination of melamine by means of L-cysteine-capped Mn-doped zinc sulfide ( $\mathrm{ZnS}$ ) quantum dots [45]. The RTP of this probe decreased linearly between $396 \mathrm{nM}-3.96 \mu \mathrm{M}$ of melamine with a LOD of $47 \mathrm{nM}$ in $10 \mathrm{mM}$ phosphate buffer (at pH 7.4). In dairy products, the recovery range of melamine was estimated as $96.3-104.7 \%$ with a RSD of $0.15 \%$. These RTP-based melamine assay tactics can be effectively tuned to quantify melamine in infant formula, raw milk, cheese, yogurt and coffee creamer, etc.

Other quantum dots and its conjugates, such as $\mathrm{CuInS}_{2} \mathrm{QDs}$, hapten-quantum dots bioconjugates (small molecules that stimulate an immune response while conjugated with a large carrier such as a protein are defined as haptens; in this case hapten = melamine) and secondary antibody 
$\left(\mathrm{Ab}_{2}\right)$-conjugated quantum dots (QDs) were also applied to melamine detection. A fluorescent "turn-on" based assay of melamine was demonstrated with CuInS ${ }_{2}$ QDs [46]. Liu et al. described the recognition of melamine by $\mathrm{CuInS}_{2}$ QDs, which had the initial fluorescence quenched by $\mathrm{H}_{2} \mathrm{O}_{2}$ oxidation. Only upon the addition of melamine, the fluorescence began to recover. This work displayed a linear concentration range of melamine from $10 \mathrm{nM}$ to $10 \mu \mathrm{M}$ with a LOD of $5 \mathrm{nM}$. This satisfactory recovery result on milk samples supports the real-time utility of this probe. However, the fluorescence quenching by oxidative step still makes the probe a complicated one.

Sanz-Medel's group developed the melamine-BSA-CdSe/ZnS QDs (BSA = Bovine Serum Albumin) conjugates and demonstrated their use in melamine detection via complementary optical spectroscopy and molecular mass spectrometry procedures [47]. In this work, a competitive immunoassay tactic was engaged for detection of melamine, where the melamine and the immunoprobe [QDs:Mel-BSA:EDC (conjugation buffer) at 2:1:1500 ratio] compete for the binding sites of the immobilized antibody. The Mel-BSA conjugates were developed by mixing Mel:BSA:EDC at 525:1:1700 ratio, which covered all the binding sites of BSA. Hence, melamine uses one of its $\mathrm{NH}_{2}$ group and leaves other two $\mathrm{NH}_{2}$ groups free to participate in the competitive immunoassay. This simple approach was also validated in melamine contaminated milk infant formula, which was in good agreement with other analytical methods. Without any sample pretreatment, a LOD $0.15 \mathrm{mg} / \mathrm{kg}$ was achieved, and hence can be applied for real-time monitoring of melamine contamination. An indirect fluorescence-linked immunosorbent assay (icFLISA) method based on secondary antibody $\left(\mathrm{Ab}_{2}\right)$-conjugated quantum dots $(\mathrm{QDs})$ was proposed for melamine detection by $\mathrm{Wu}$ and co-workers [48]. A LOD of melamine of $3.88 \mathrm{ng} / \mathrm{mL}$ was achieved, which was better than that of previous reports. Moreover, this method displayed recoveries between $80.85-110.54 \%$ with 2.82 8.82\% RSDs in milk samples. The above QD-antibody-based immunoassay can be applied for rapid real-time screening of melamine in dairy products. However, these antibody-based QDs approaches still require sophisticated and costly biological instruments. The existence of other nitrogen enriched enzymes may considerably affect the selectivity of antibody-based QDs in melamine detection, which also extend the response time due to transport barrier.

\section{Metal Nanoclusters Towards Melamine Determination}

Similar to the carbon and quantum dots, luminescent metal nanoclusters were also applied in the screening of melamine contamination in milk products and infant formula. For instance, Dai et al. demonstrated BSA-stabilized gold nanoclusters (BSA-Au NCs) for the potential assay of melamine in raw milk and milk powder with good recoveries [49]. In this study, they proposed the fluorescent "turn-on" strategy for melamine recognition using anti-quenching capability of $\mathrm{Hg}^{2+}$ to BSA-Au NCs. The emission from the Au NCs was quenched by $\mathrm{Hg}^{2+}$ ions, then restored in the presence of melamine. Hence, this method can be applied for the identification of melamine adulteration in dairy products. This assay technique displayed linearity between $0.5-10 \mu \mathrm{M}$ with a LOD of $0.15 \mu \mathrm{M}$. Moreover, its recovery range was between 93 102.5\% with 2.69 4.52\% RSDs in raw and powder milk samples. In this track, Yang and Liao's research groups developed the tiopronin-stabilized gold nanoclusters (TPN-Au NCs) for the discrimination of melamine by means of fluorescence quenching as shown in Figure 6 [50]. The probe displayed a linearity between $0.09-100 \mu \mathrm{M}$ with a LOD of $32 \mathrm{nM}$. Potentiality in melamine detection of the probe was authenticated by its recoveries in spiked infant formulas, which was estimated as $92 \sim 102.2 \%$ and $1.14 \sim 2.80 \%$ RSDs. 


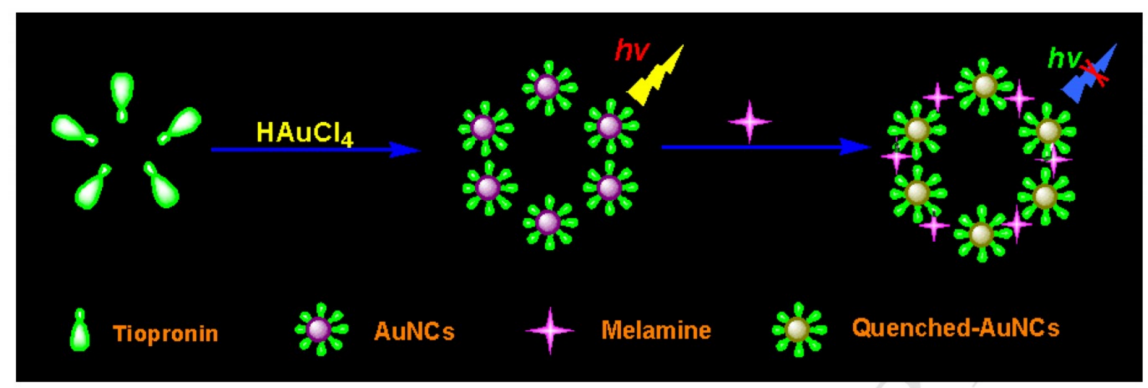

Figure 6. Scheme of the synthetic strategy for tiopronin-stabilized gold nanoclusters (TPN-AuNCs) and the principle of melamine sensing (reproduced with permission from Reference [50]).

On the other hand, Wang's research described the colorimetric recognition of melamine through reversing the inhibition of $\mathrm{Hg}$ (II) mediated light-triggered activity of horse-radish peroxidase (HRP) functionalized gold nanoclusters (HRP-Au NCs) [51]. In fact, the catalytic activity of HRP-Au NCs was restored by triazole ring of melamine via inhibition of the metallophilic interaction as mentioned in Reference [49]. It led to linear colorimetric "turn-on" assay of melamine between $0.2-15 \mu \mathrm{M}$ with a LOD of $72 \mathrm{nM}$. Recoveries of this study in raw milk and milk powder were at the range from 98.5 to $101.5 \%$. The above $\mathrm{Hg}$ (II) mediated sensing approach was further modified by Lin and co-workers [52]. They synthesized the BSA-Au NCs by microwave-assisted synthetic path and then applied in melamine detection as reported earlier. The melamine detection limit proposed in this work is $2.94 \mu \mathrm{M}$. However, apart from the synthetic route, this work describes the similar notion reported by Dai et al. Hence it cannot be attested as a suitable method for melamine recognition in dairy nutrients.

Melamine determination using glutathione-protected gold nanoclusters (GSH-Au NCs) was presented by Kalaiyarasan et al. through the fluorescence-based ratiometric assay [53]. Upon the addition of melamine, the photoluminescence (PL) intensity at $610 \mathrm{~nm}$ decreased along with enhanced ratiometric PL at $430 \mathrm{~nm}$. The results were attributed to the hydrogen-bonding interaction between the melamine and AuNCs, which led to the aggregation of Au NCs. The proposed method applied in cow milk and infant formulas demonstrated recoveries between 94 97.1\% with 1.24 3.95\% RSDs. Furthermore, these GSH-Au NCs recognized the melamine with a LOD of $28.2 \mu \mathrm{M}$, hence can be applied in real-time screening of melamine. More recently, Lin and co-workers established the efficiency of egg-white protected gold nanoclusters (ew-Au NCs) through microwave technique [54]. However, the melamine detection by ew-Au NCs displayed the similar $\mathrm{Hg}$ (II) mediated approaches as described earlier [49,52]. The reported melamine detection has an LOD of $0.46 \mu \mathrm{M}$ and recovery percentile range from 92.9 to $106 \%$ with RSD of $2.9 \%$. Even though the author claimed the method innovative, however, their approach has already been established by earlier reports.

In 2012, Xu and co-workers reported the oligonucleotide-stabilized fluorescent silver nanoclusters (DNA-Ag NCs) towards "turn-on" recognition of melamine [55]. In that study, the linear melamine concentration fixed at $50 \mathrm{nM}$ to $7 \mu \mathrm{M}$ with a LOD of $10 \mathrm{nM}$ was reported. The probe also identified the melamine in raw milk samples with recoveries from 100.4 to $107 \%$. Similar to the functionalized $\mathrm{Au}$ NCs, hyper-branched polyethyleneimine-capped silver nanoclusters (PEI-Ag NCs) were employed in $\mathrm{Hg}$ (II) mediated melamine assay [56]. Qu and You's research groups developed the PEI-Ag NCs for $\mathrm{Hg}$ (II) induced melamine determination via "turn-on" fluorescent recovery. The linear detection range of melamine determination and LOD were estimated as 0.1 to $30 \mu \mathrm{M}$ and $30 \mathrm{nM}$, respectively. Interestingly, recoveries from 96 to $101 \%$ were observed in food products. However, the idea and the approach of this work is the same as those of the Au NCs, except for the metallic cluster part. Hence its real-time applicability is questionable.

As an addition to the Ag NCs-based melamine sensors, Ren et al., discussed the utility of chromotropic acid and layered double hydroxides functionalized silver nanoclusters (CTA-Ag $\mathrm{NCs} / \mathrm{LDH}$ ) directed for fluorescence turn-on assay of melamine [57]. Ultrathin film consisting of CTA-Ag NCs and layered double hydroxide nanosheets (LDH) was fabricated via layer-by-layer (LBL) 
assembly and was demonstrated successfully in the discrimination of melamine. In the presence of melamine, the fluorescence of ultrathin film displayed the "turn-on" response among other competitive species. Linearity of melamine quantification was observed from 0.03 to $0.1 \mu \mathrm{M}$ with a LOD of $4 \mathrm{nM}$. This work uses the novel strategy of immobilization of metal nanoclusters into an inorganic matrix, which may enhance the upcoming research towards chemical and biosensing. As presented earlier [56], $\mathrm{Hg}$ (II) mediated melamine detection was conducted by Xie and co-workers [58]. In that study they also used the DNA-Ag NCs to expose the strong fluorescence recovery with melamine as shown in Figure 7. Linear melamine assay range was demonstrated between 0.2 to $4 \mu \mathrm{M}$ with a LOD of $0.1 \mu \mathrm{M}$. This work is a duplication of earlier reports, hence cannot be considered as a suitable technique for real-time monitoring of melamine in dairy and food products.

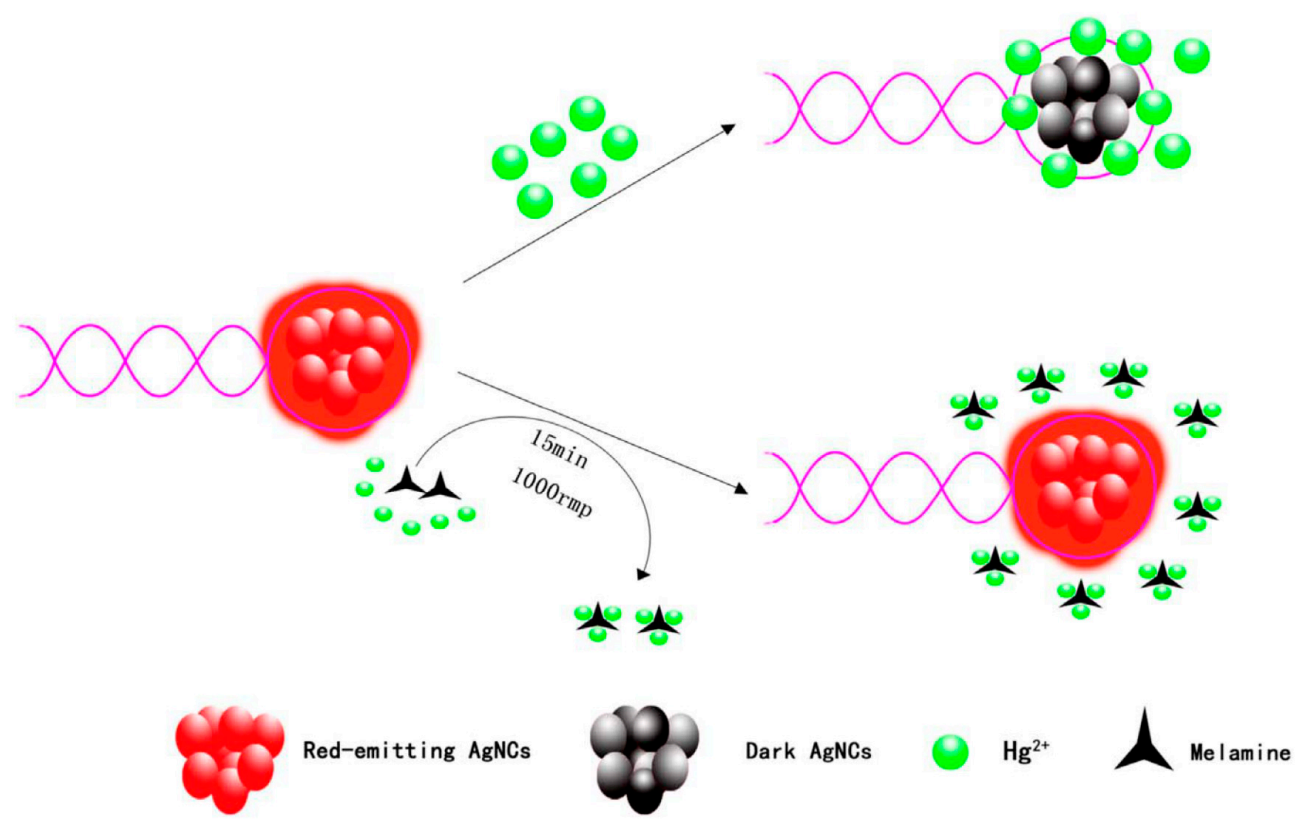

Figure 7. A fluorescence turn-on strategy for detecting melamine based on the coordination between melamine and $\mathrm{Hg}^{2+}$ (reproduced with permission from Reference [58]).

Studies on the metallic-interaction-induced quantification of melamine were further stimulated by the recent reports from $\mathrm{Li}$ and Luo's research groups [59]. They employed the lipoic acid-stabilized silver nanoclusters (LA-Ag NCs), which emitted red fluorescence with $\mathrm{Cu}$ (II) and then facilitated melamine detection. The LA-Ag NCs displayed the aggregation-induced emission, which was then quenched with the addition of $\mathrm{Cu}$ (II) ions due to dispersion. Upon reaction with melamine, the emission restored to its original stage via formation of melamine- $\mathrm{Cu}(\mathrm{II})$ complex and then led to aggregation again. The LOD of melamine recognition was estimated as $174 \mathrm{nM}$; the recoveries and RSDs were oscillated from 98 to $113.3 \%$ and 3.12 5.30\%, respectively. Although the work seems to be impressive, it can only be considered as a regular metallic-interaction-mediated melamine assay. On this path, Hou et al. presented silver nanocluster arrays over large-area silica nanosphere template for surface-enhanced Raman spectroscopy (SERS)-based assay of melamine with a lowered LOD of $100 \mathrm{nM}$ [60]. Such a template-based assay approach can be directed toward real-time screening of melamine dairy and food products.

Luminescent copper nanoclusters were also engaged in melamine sensing as described next. Polythymine-stabilized copper nanoclusters were utilized for melamine recognition via enhanced fluorescence of $\mathrm{Cu}$ NCs [61] as seen in Figure 8. The linear melamine assay concentration was fixed between 0.1 and $6 \mu \mathrm{M}$ with a LOD of $95 \mathrm{nM}$ and the recoveries of spiked milk samples were established at 92 to $110 \%$ with $2 \sim 9.8 \%$ RSDs 


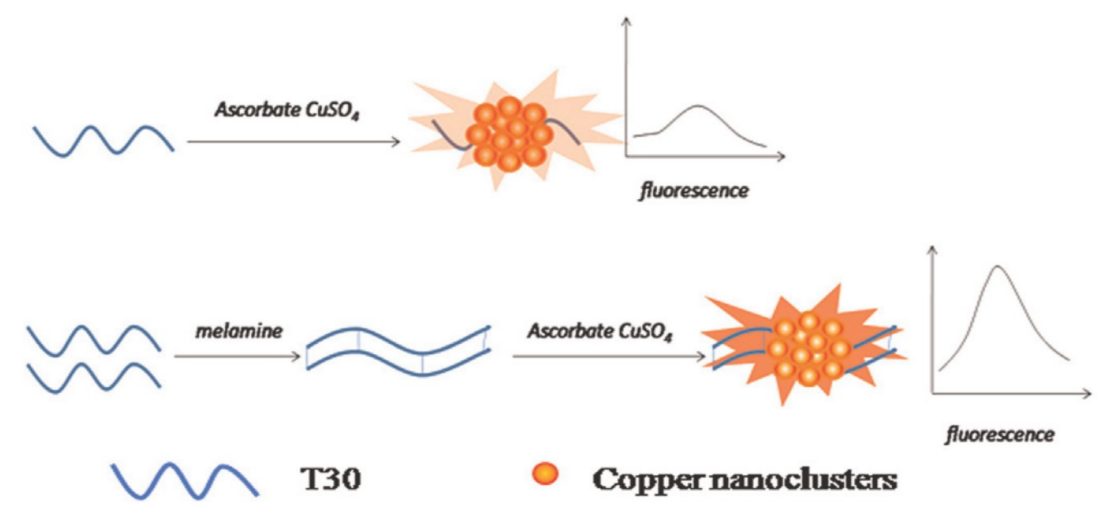

Figure 8. A scheme illustrating the melamine sensing based on the fluorescence enhancement of copper nanoclusters (reproduced with permission from Reference [61]).

\section{Melamine Assay by Nanocomposites}

Many nanocomposites have been reported as proficient candidates for melamine quantification, as described in this section. In 2011, Chen and co-workers presented the silver nanoparticle-decorated silver/carbon nanospheres $(\mathrm{Ag} / \mathrm{C} / \mathrm{AgNps})$ as a composite candidate for SERS-based assay of melamine [62]. The effect of heavy metal ions on the determination of melamine was described in this report. The LOD of melamine was calculated to be as low as $50 \mathrm{nM}$, hence confirmed the good SERS activity of $\mathrm{Ag} / \mathrm{C} / \mathrm{AgNps}$ nanosphere composite. This is a unique technique and can be employed for real-time melamine screening in the presence of metal ions. Next, composites consisting of silver nanoparticles and glutathione capped zinc selenide quantum dots (GSH-ZnSe QDs) were exploited for melamine sensing in Cao's work [63]. As shown in Figure 9, the inner filter effect property (IFE) of Ag NPs is influenced by the fluorescence of GSH-ZnSe QDs and plays a vital role in the sensing process, wherein the initial non-aggregated Ag NPs are transformed to aggregated state in the presence of melamine, which provide the strong emission with GSH-ZnSe QDs. On the other hand, the mixture of Ag NPs and GSH-ZnSe QDs shows weak emission. The linear regression for melamine is observed between 7.93 to $285 \mathrm{nM}$ with a LOD of $872 \mathrm{pM}$. This IFE-based sensing strategy is satisfactorily applied for melamine assay in raw milk and egg samples and has recoveries between 97.2 to $102.1 \%$ with corresponding RSDs among 0.7 to $3.7 \%$. The above IFE-based tactic can be a suitable method for real-time scrutinizing of melamine in milk and food.

Regarding the composite nanomaterial-based analytical approach, a sandwich-type composite assembly is described as follows. Sarkar et al. presented the para-phenylenediamine (PDA) sandwiched between a nanostructured silver nanoparticle film and gold core-silver shell nanoparticles, which was further applied in SERS-based detection of melamine at femtomolar $\left(10^{-15} \mathrm{M}\right)$ level [64]. These tailored sandwich-based approaches provide the innovative ways towards the development of SERS substrates which can be utilized in bio- and chemical sensors. However, the complications and the requirement of costly instruments to fabricate such substrates need to be overcome.

Towards the development of cost-effective SERS composite substrates for melamine recognition, $\mathrm{Wu}$ and Roy's research group developed the screen printed silver nanoparticles (Ag NPs) over a polyethylene terephthalate (PET) substrate [65]. Here the SERS-based melamine assay was established in liquid milk, but the clear linear ranges and limits were absent. Moreover, these substrates were also engaged to detect Rhodamine 6G (R6G) and Malachite green (MG) etc. Hence, more efforts are required in order to use these substrates towards melamine detection. A microfluidic chip consisting of an indium tin oxide (ITO) support modified with silver-gold nanocomposite (Ag-Au NCs) was demonstrated in the SERS-based determination of melamine by Wang and co-workers [66]. The results predicted a linear detection range of melamine from $10 \mathrm{nM}$ to $0.1 \mathrm{mM}$ with a LOD of $10 \mathrm{nM}$. On the other hand, this chip also shows sensitivity to 4-mercaptobenzoic acid (4-MBA) with a LOD of $0.1 \mathrm{nM}$. Therefore, it can act as an effective tool for melamine and biochemical analysis. 


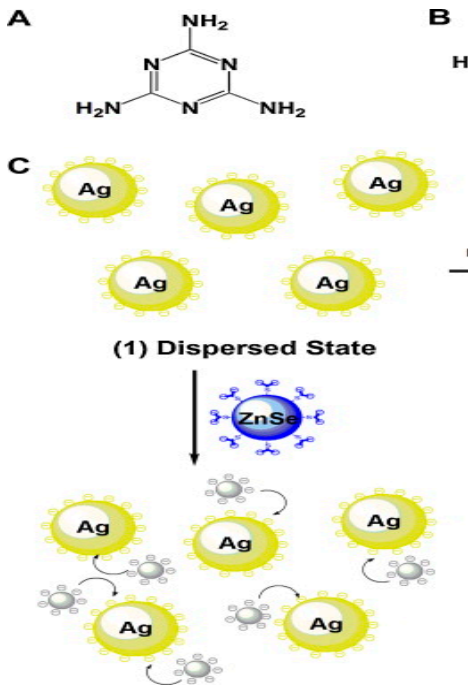

(2) Weak Emission<smiles>[B]OC(=O)CCCC(=O)NC(C[C@H](N)CCC(=O)O)C(=O)NCC(=O)O</smiles>

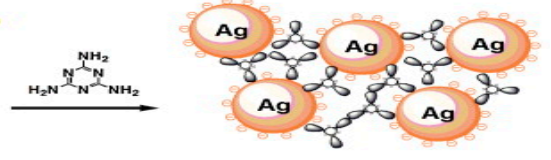

(3) Aggregated State

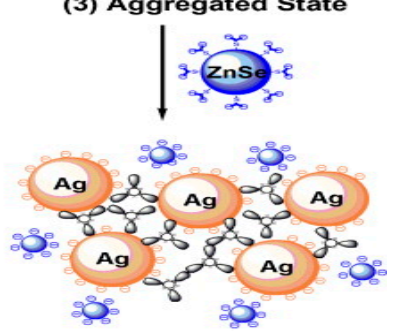

(4) Strong Emission
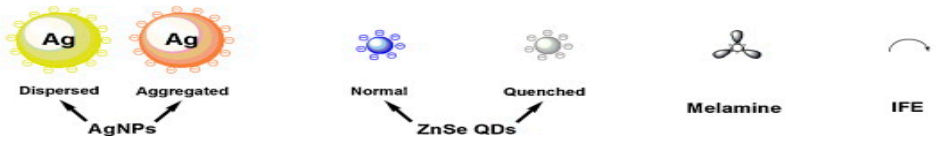

Figure 9. The molecular structures of melamine (A) and l-GSH (B); Schematic illustration of the "turn-on" fluorescent detection of melamine based on the inner filter effect (IFE) of AgNPs on ZnSe QDs (C) (reproduced with permission from Reference [63]).

Subsequently, Han et al. applied silver nanocontacts onto silica nanospheres $\left(\mathrm{SiO}_{2} @ \mathrm{Ag}\right)$ for SERS-based sensory studies [67]. The above composite substrate was employed in the SERS-based assays of various environment pollutants, such as thiram, melamine, and ethyl-parathion. Moreover, the estimated LOD for melamine assay was $1 \mathrm{nM}$. The $\mathrm{SiO}_{2} @ \mathrm{Ag}$ can be considered as one of the best SERS probes for multiple analyte detection. In 2011, Wang's research group demonstrated the SERS-based melamine assay using silver nanoparticle coated poly(styrene-co-acrylic acid) nanospheres (PSA/Ag NPs) [68]. Wherein, the composite [PSA/Ag-NPs/polyvinylpyrrolidone (PVP)] displayed a lower LOD on melamine detection near $1 \mathrm{mM}$ in the presence of PVP. However, upon the removal of PVP, the LOD was enhanced to $100 \mathrm{nM}$. This work is also included the SERS-based sensing studies and can be further directed towards in vivo diagnostics and multimodal imaging [69].

An ultrasensitive colorimetric assay of melamine was delivered by Wang and co-workers through in situ reduction to form the carbon quantum dots (CQDs)-silver nanocomposite [70]. As shown in Figure 10, the solution in the presence of melamine changes its color. Under optimum conditions, the linearity of melamine assays was from $793 \mathrm{pM}$ to $79.3 \mathrm{nM}$ and $198 \mathrm{nM}$ to $3.96 \mu \mathrm{M}$ with a LOD of $62.6 \mathrm{pM}$. Furthermore, the work described the melamine recoveries in cow milk and milk powder, which were between $87.6 \sim 116 \%$ with 1.6 3.9\% RSDs. This colorimetric detection approach can be used for real-time screening of melamine in food stuffs. In addition, polydopamine-glutathione nanoparticles and silver nanoparticles were employed to melamine discrimination based on the fluorescence resonance energy transfer (FRET) effect as demonstrated in Figure 11 [71]. In the presence of melamine, the $\mathrm{Ag}(\mathrm{I})$ - melamine complex was formed, which prevented the generation of Ag NPs to show the fluorescence "turn-on" response. In contrast, in the absence of melamine, Ag NPs were formed and hence no fluorescence was observed. The linear response to the concentration of melamine was from 0.1 to $40 \mu \mathrm{M}$ with a LOD of $23 \mathrm{nM}$. The recoveries of melamine in milk, yogurt and infant formula stretched from 99.4 to $104.2 \%$ with $2.46 \sim 4.83 \%$ RSDs. Due to its simplicity in operation, this method can be directed towards real-time screening of melamine. 


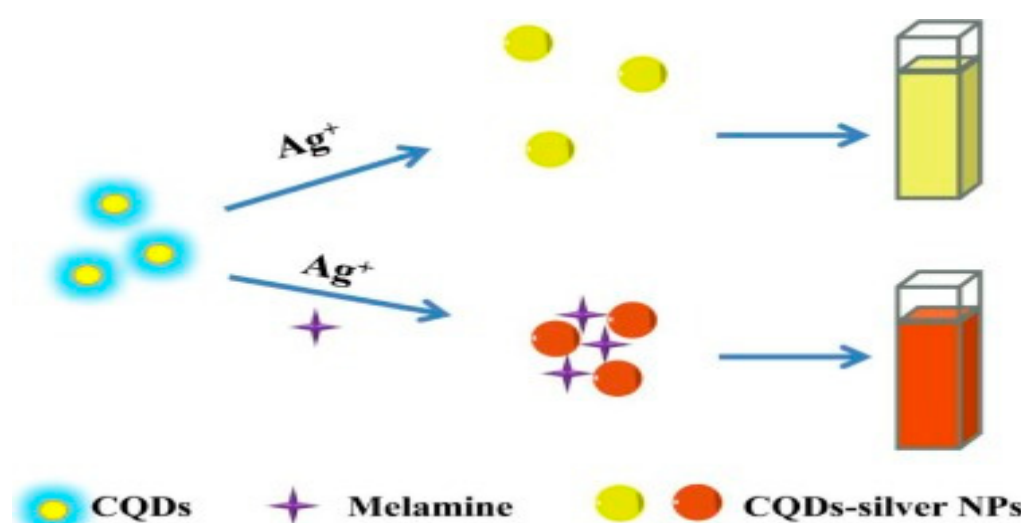

Figure 10. Schematic illustration of the colorimetric sensing of melamine based on in situ formation of CQDs-silver NPs (reproduced with permission from Reference [70]).
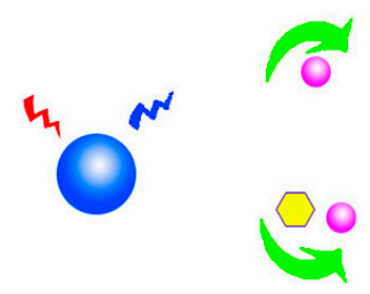

:PDA-GNPs
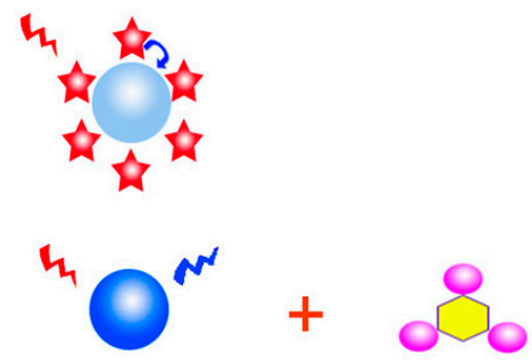

$: \operatorname{Ag}(\mathrm{I})$

: Melamine

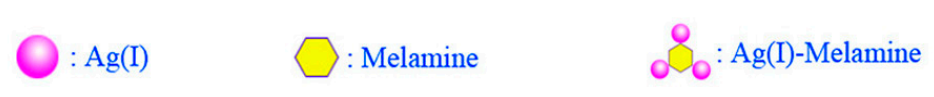

Figure 11. Schematic illustration of the sensing mechanism of melamine in the absence and presence of melamine (reproduced with permission from Reference [71]).

Manzoori et al. presented a beneficial effect of gold/silver alloy nanoparticles (Au/Ag NPs) on the chemiluminescence of permanganate-formaldehyde system in the presence of sodium dodecyl sulfate micelles [72]. Wherein, the trace of melamine inhibited the reaction of nanoparticles, which promoted the generation of $\mathrm{Mn}(\mathrm{II})^{*}$ and enhanced the chemiluminescence intensity. Therefore, chemiluminescence of the above composite system was quenched considerably with melamine. The linear determination range for melamine was projected from $79.3 \mathrm{pM}$ to $277.5 \mathrm{nM}$ with a LOD of $63.4 \mathrm{pM}$. In powdered milk samples, the melamine recoveries were between $93.7 \sim 104.5 \%$ with $0.3 \sim 3.5 \%$ RSDs. Even though this work is considered as a good analytical approach, additional authentication is still required to enhance its real-time reliability. In this light, Sun and Zhang's report described the IFE of gold nanoparticles on the fluorescence of CdTe quantum dots, which led to fluorescence "turn-on" response [73]. Under optimized condition the detection limit of melamine was calculated to be $158.6 \mathrm{nM}$.

Yue and co-workers established the ability of gold nanoparticles deposited $\beta$-FeOOH nanorods $(\mathrm{Au} / \beta-\mathrm{FeOOH}$ nanocomposites) in composite-based melamine recognition due to the promotion of symmetry-forbidden bands $\left(n-\mu^{*}\right)$ of melamine [74]. Apart from detection mechanism, the assay of melamine in this work is insufficient, hence the reliability of this work is still questionable. Next, an electrode modified with gold nanoparticles and reduced graphene oxide (AuNPs/rGO) was demonstrated by Chen et al. towards the discrimination of melamine in food contact materials [75]. They used the hexacyanoferrate as a reporter in this electrochemical sensing. Its response was affected by the increase in the concentration of melamine. The linear regression of melamine assay was from 
5 to $50 \mathrm{nM}$ with a LOD of $1 \mathrm{nM}$ and the sensing was also validated in food articles. The above electrochemical assay method can be effectively directed towards melamine detection in food and dairy objects.

Yang's research group engaged the studies on the functionalized $\mathrm{Au}-\mathrm{Fe}_{3} \mathrm{O}_{4}$ nanocomposites for magnetic and colorimetric bimodal recognition of melamine [76]. They modified the $\mathrm{Au}-\mathrm{Fe}_{3} \mathrm{O}_{4}$ nanocomposites with 1-(2-mercaptoethyl)-1,2,3,4,5,6-hexanhydro-s-triazine-2,4,6-trione (MTT) and used them in bimodal sensing of melamine. In the presence of melamine, the color of the Au-Fe3O4@MTT NPs changes from red to completely colorless, hence can be used for naked-eye and on-site qualitative determination of melamine. Besides, the composite shows a linear response between 6 to $22 \mu \mathrm{M}$ of melamine concentrations. However, this result still needs more work towards electrochemical sensors. Following this path, gold nanoparticles deposited on a graphene doped carbon paste was employed as an electrode for electrochemical sensing of melamine [77]. Melamine interacts with gold nanoparticles to supress the peak current. From 0.2 to $800 \mathrm{nM}$ and $800 \mathrm{nM}$ to $8 \mathrm{mM}$ concentrations of melamine, the peak current displayed a good linear relationship with a LOD of $18 \mathrm{pM}$. The above quantitative melamine determination was validated by its recoveries in spiked milk samples, which were between $95.00 \sim 101.75 \%$ with $0.09 \sim 3.16 \%$ RSDs. Although this work is impressive, it requires a complicated fabrication processes.

Other than the earlier extensive works on the SERS-based discrimination [65-69], Neng's report also detailed the SERS-based discrimination of melamine by using $\mathrm{Fe}_{3} \mathrm{O}_{4} / \mathrm{Au}$ magnetic nanoparticles coated with 5-aminoorotic acid (AOA) as a substrate [78]. In their studies, the SERS substrate $\left(\mathrm{Fe}_{3} \mathrm{O}_{4} / \mathrm{Au}-\mathrm{AOA}\right)$ and Rhodamine $\mathrm{B}(\mathrm{RhB})$ binded $\mathrm{AOA}(\mathrm{AOA}-\mathrm{RhB})$ were engaged as a Raman reporter, which forms the supramolecular complex with melamine $\left[\mathrm{Fe}_{3} \mathrm{O}_{4} / \mathrm{Au}-\mathrm{AOA} \bullet \bullet \bullet m e l a m i n e \bullet \bullet A O A-\mathrm{RhB}\right]$ via H-bonding as illustrated in Figure 12. From 19.8 to $119 \mu \mathrm{M}$, the linear regression of melamine was observed with a LOD of $19.8 \mu \mathrm{M}$.

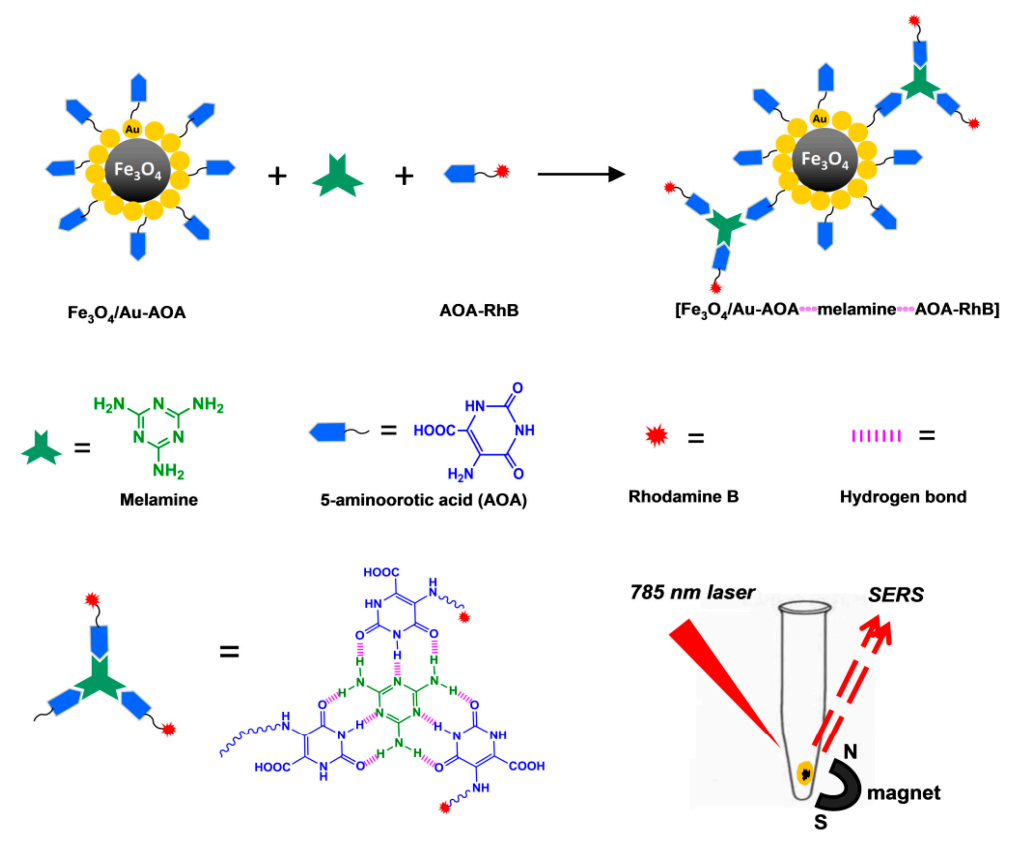

Figure 12. The $\mathrm{H}$-bonding assisted $\left[\mathrm{Fe}_{3} \mathrm{O}_{4} / \mathrm{Au}-\mathrm{AOA} \bullet \bullet \bullet\right.$ melamine $\left.\bullet \bullet A O A-\mathrm{RhB}\right]$ surface-enhanced Raman spectroscopy (SERS) matrix (reproduced with permission from Reference [78]).

Although this method possesses the complicated fabrication processes for Raman substrates, it avoids the sample pre-treatment steps, and hence is important in real-time monitoring of melamine. Rao et al. presented a novel electrochemical sensors by means of surface modified Glassy carbon electrode (GCE) with Au and polyaniline composites in the melamine screening, which enhanced the electrode sensitivity and sensor signal amplification [79]. During sensing processes, melamine 
assembled on the Au@PANI via hydrogen bonds, which led to diverse electrochemical signal. LOD of melamine assay was estimated to be $1.39 \mu \mathrm{M}$. In spiked milk samples the recoveries were between 90.8 98.3\% and 89.5 91.3\%. This electrochemical method can be employed for on-site inspection of melamine in dairy and food products.

Niu and co-workers invented a novel dual-emission ratiometric fluorescence probe to determine melamine by combining the organic nanoparticles with aggregation-induced emission (AIE) characteristics and gold nanoclusters (Au NCs) through electrostatic interaction [80]. The above composite system (AIE-OFNs/ Au NCs) with quenched emission at $625 \mathrm{~nm}$ detects the melamine through anti-quenching ability of Au NCs-Hg(II). Upon the addition of melamine, the fluorescence recovered back to its original state via $\mathrm{Hg}$ (II)-melamine link. The melamine recoveries in spiked powder milk samples were from 90 to $96.4 \%$ with $1.84 \sim 4.40 \%$ RSDs. The above record is an inclusion to the metal mediated melamine recognition. In the electrochemical-based determination of melamine, Dey et al. used a reduced graphene oxide-gold nanoparticle composite carbon paste as an electrode to recognize melamine by spotting the decrease in the oxidation of ferrocyanide [81]. This work also demonstrated good recoveries for melamine detection in milk powder and tap water. This work displayed a linear dynamic range from 5 to $160 \mu \mathrm{M}$ with a LOD of $2.23 \mu \mathrm{M}$.

As an inclusion to SERS-based melamine discovery, a substrate containing curved-edge gold nanocubes (CENCs) and Au nanospheres (Au NSs) were demonstrated by Lv and co-workers [82]. The SERS substrate showed sensitivity to melamine with a LOD of $1 \mathrm{nM}$ due to a tip-gap mesh structure. Mixture of carbon dots (C-dots) and gold nanoparticles (Au NPs) was reported towards fluorescence resonance energy transfer (FRET) based assay of melamine by Li's group [83]. The fluorescence of $\mathrm{C}$-dots, which was quenched by Au NPs via FRET, recovered during the sensing process. The melamine recognition expressed the linearity from $50 \mathrm{nM}$ to $500 \mathrm{nM}$ with a LOD of $36 \mathrm{nM}$. These FRET-based melamine detection was also demonstrated through good recoveries in raw milk and milk powders, which were between $90.45 \sim 111.35 \%$ with $0.72 \sim 2.05 \%$ RSDs, and hence can be proficient in real-time monitoring of melamine.

On this track, $\mathrm{Qu}$ and co-workers presented a new ratiometric fluorescence probe via self-assembly of carbon nanodots and glutathione-stabilized gold nanoclusters (CNDs/GSH@Au NCs) for the selective discrimination of melamine [84]. Similar to their previous report [56], this study also demonstrated the anti-quenching ability of melamine to CNDs/GSH@Au $\mathrm{NCs}-\mathrm{Hg}^{2+}$, and hence can be considered as an addition to the metal mediated melamine assay. The linear melamine detection concentration was from 0.1 to $30 \mu \mathrm{M}$ with a LOD of $29.3 \mathrm{nM}$. Rovina et al. described an electrochemical sensor composed of ionic liquid/zinc oxide nanoparticles/chitosan/gold electrode for melamine identification [85]. The authors used the (1-ethyl-3-methylimidazolium tri-fluoromethanesulfonate ([EMIM][Otf])) as ionic liquid, $\mathrm{ZnO}$ nanoparticles, chitosan nanocomposite membranes and gold electrode for melamine assay. The dynamic melamine detection concentration was from $0.96 \mathrm{pM}$ to $0.96 \mu \mathrm{M}$ with a LOD of $96 \mathrm{fM}$. The proposed method showed the melamine recoveries between $95.4 \sim 97.5 \%$ with $0.41 \sim 0.81 \%$ RSDs. Although this work shows the lowest LOD on melamine sensing, steps for fabrication of electrodes involve many complications, and hence much effort is still required.

Fluorescence energy transfer among CdTe-doped silica nanoparticles $\left(\mathrm{CdTe} @ \mathrm{SiO}_{2}\right)$ and gold nanoparticles (Au NPs) towards melamine determination was proposed by Gao and co-workers [86]. Wherein, upon the addition of $\mathrm{Au} \mathrm{NPs}$ to $\mathrm{CdTe} @ \mathrm{SiO}_{2}$, the fluorescence was quenched and then recovered in the presence of melamine. The melamine assay showed linearity between 7.5 to $350 \mathrm{nM}$ with a LOD of $0.89 \mathrm{nM}$. This method also applied in raw milk and milk powder samples with exceptional recoveries between 97.4 104.1\%, and hence can be utilized towards the screening of melamine in dairy products. On this path, a FRET-based melamine detection was discussed in Su's research report [87] which proposed the FRET between 3-Mercaptopropionic acid-capped CdTe QDs and Rhodamine B for the quantification of melamine. A linear quenching by melamine was achieved between $0.05 \sim 4.0 \mu \mathrm{M}$ with an LOD of $0.01 \mu \mathrm{M}$. The above method was validated with melamine 
recoveries in spiked milk samples, which were from 99.2 to $104 \%$ with $2.9 \sim 3.5 \%$ RSDs. However, continuing efforts are still required to improve the potential of this work.

A composite comprised of CdTe/CdS QDs and Au NPs was engaged in the assay of melamine by Zhao and collaborators as described in Reference [88], in which FRET between CdTe/CdS QDs and Au NPs led to the "turn-on" detection of melamine. Upon addition of melamine to the above composite (CdTe/CdS QDs and Au NPs), the fluorescence was enhanced linearly between $50 \mathrm{nM}$ to $1 \mu \mathrm{M}$ with a LOD of $30 \mathrm{nM}$. This method displays good recoveries for the melamine recognition in raw milk and milk products, which are from 90 to $101 \%$. However, this tactic is only an inclusion to the FRET-based composite sensors for melamine. Next, an IFE-based melamine determination was demonstrated by Zhu et al. through a CdTe QDs and Au NPs composite system [89] which showed the emission quench at $525 \mathrm{~nm}$ by the addition of Au NPs to CdTe QDs via IFE and then visualized the enhancement of fluorescence in the presence of melamine. On the other hand, the emission at $620 \mathrm{~nm}$ was not affected with the existence of Au NPs, but the addition of melamine led to complete quenching of emission. Hence, this probe can be used as a dual-mode fluorescent probe for melamine detection as illustrated in Figure 13. The linear melamine concentration determined by this method was from 158.6 to $793 \mathrm{nM}$ with a LOD of $87 \mathrm{nM}$. Moreover, melamine recoveries in milk samples were between $97.7 \sim 104.9 \%$ with 2.7 4.0\% RSDs. Due to the dual "turn-on" and "turn-off" responses, the probe can be effective towards melamine assay in dairy samples.

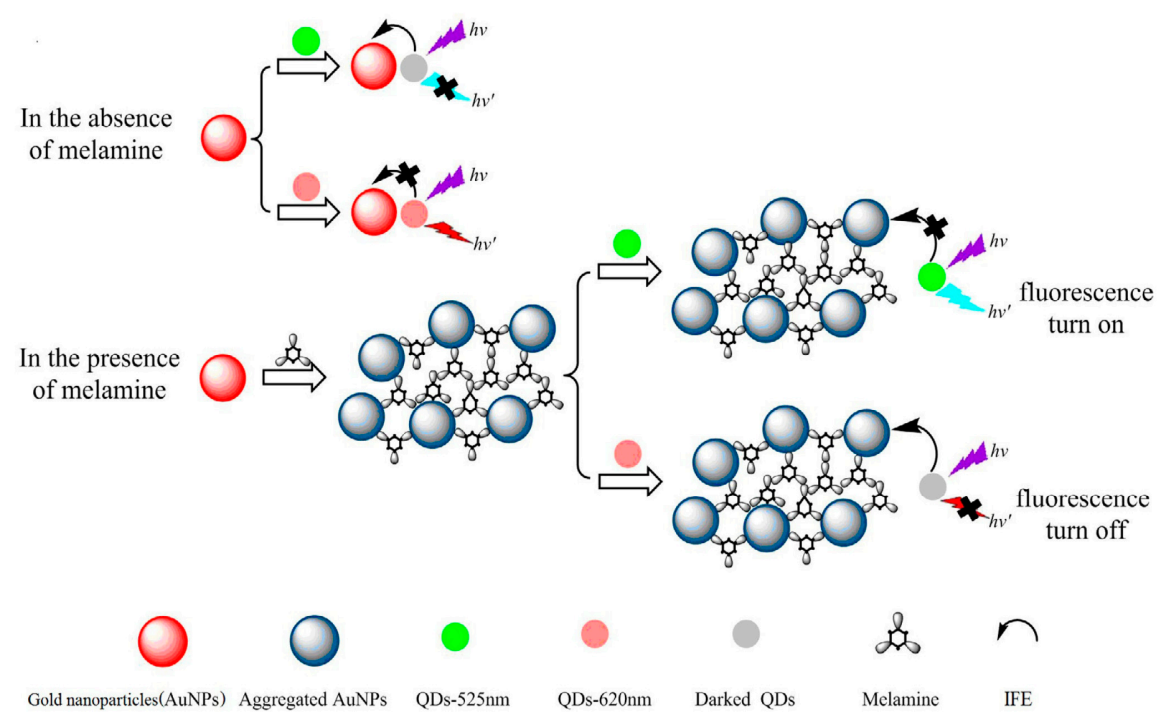

Figure 13. Schematic illustration of the dual-mode fluorescent probe for melamine detection (reproduced with the permission of Reference [89]).

A solid-state electrochemiluminescent sensor based on $\mathrm{C}_{60}$ /graphite-like carbon nitride nanosheet $\left(\mathrm{C}_{60} / \mathrm{g}-\mathrm{C}_{3} \mathrm{~N}_{4} \mathrm{NS}\right)$ hybrids was developed to quantify the melamine by $\mathrm{Fu}$ and co-workers [90]. The linear concentrations of melamine assay were between 0.5 to $27 \mathrm{pM}$ and $27 \mathrm{pM}$ to $19 \mathrm{nM}$ with a LOD of $0.13 \mathrm{pM}$. This method can be considered as a suitable electrochemiluminescent (ECL) method for melamine discrimination due to its picomolar level detection ability. Moreover, the accuracy of this method is reliable to well established HPLC-MS analytical methods.

Similar to the above report, electrochemiluminescence property of the silica nanoparticles doped with $\left[\mathrm{Ru}(\mathrm{bpy})_{3}\right]^{2+}$ and molecularly-imprinted polymer (MIP) were utilized to modify the glassy carbon electrode for selective sensing of melamine by Lian and co-workers [91]. Here, MIP was used as a recognition source towards melamine, which resulted in ECL signal enhancement of $\left[\mathrm{Ru}(\mathrm{bpy})_{3}\right]^{2+}$. The linear regression was observed between $1 \mathrm{pM} 100 \mathrm{nM}$ with a LOD of $5 \times 10^{-13} \mathrm{~mol} / \mathrm{L}$. Moreover, the recoveries were from 90.0 to $104.0 \%$ with 4.2 to $5.3 \%$ RSDs in milk samples. Due to the lower 
detection limits, this method can be used as an effective detection technique for melamine detection in real samples.

Metal-organic frameworks mediated nafion nanohybrid (MOFs@XC-72) composite was employed by Zhang et al. to modify the glassy carbon electrode towards the detection of melamine [92]. This hybrid system comprises of XC-72, MOFs-MIL-53 and Nafion which discriminates the melamine as represented in Figure 14. The linear correlation for melamine assay was between 0.04 to $10 \mu \mathrm{M}$ with a LOD of $0.005 \mu \mathrm{M}$. In spiked milk samples, recoveries were from $98 \sim 103.5 \%$ with $3.1 \sim 4.8 \%$ RSDs. Due to the complication in electrode fabrication, this work can be only considered as an addition to electrode-based melamine sensors.

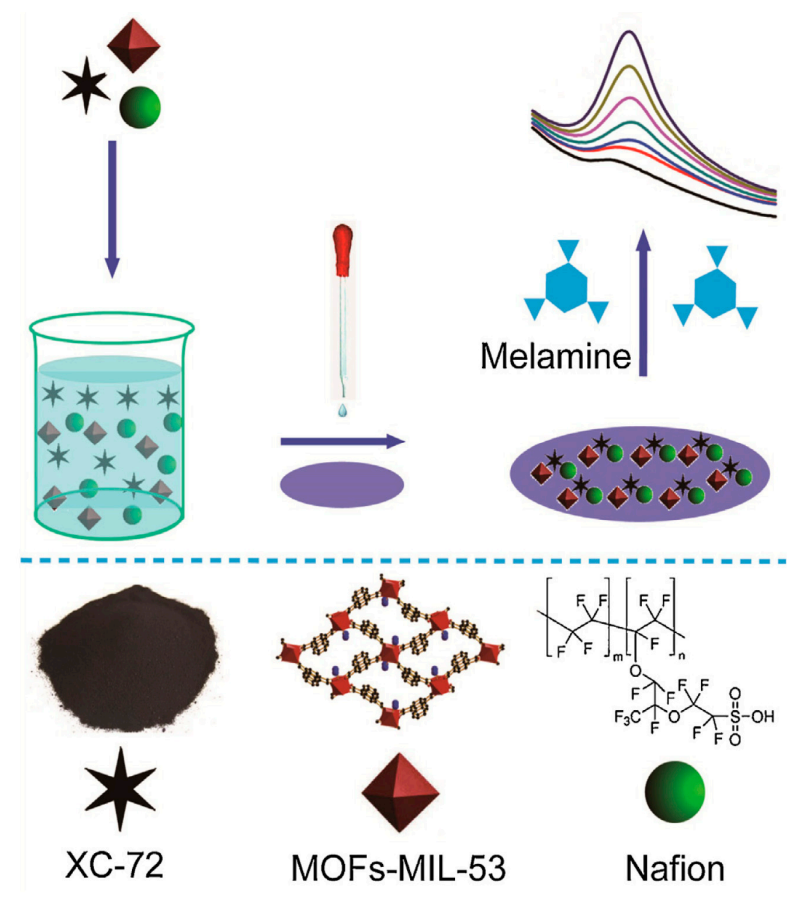

Figure 14. The illustration of the electrode preparation and application process (reproduced with permission from Reference [92]).

Gelatin-coated cerium oxide $\left(\mathrm{Gel}-\mathrm{CeO}_{2}\right)$ nanospheres were reported in Jin's research work [93], in which he conveyed the peroxidase-like activity by means of $\mathrm{H}$-bonding. The $\mathrm{Gel}-\mathrm{CeO}_{2}$ catalysed the oxidation of ABTS(2,20-azino-bis(3-ethylbenzothiazoline-6-sulfonic acid) diammonium salt) by $\mathrm{H}_{2} \mathrm{O}_{2}$ which resulted in the formation of blue color product. However, the above process was affected by the presence of melamine, which reacted with $\mathrm{H}_{2} \mathrm{O}_{2}$ via $\mathrm{H}$-bonding and changed the color of the solution to pale. The detected concentration range of melamine was from $50 \mathrm{nM}$ to $5.0 \mathrm{mM}$ with a LOD of $5.5 \mathrm{nM}$. Melamine recoveries in spiked milk samples were from 98.6 to $104.0 \%$ with $4.2 \%$ RSD. Due the simplicity and the naked-eye detecting ability, this method can be used in real-time monitoring of melamine. Notably, all of the aforementioned composite-based research approaches enhance the contaminant detection such as melamine, clenbuterol, and other poisonous produces in food packaging industries [94].

\section{Nanocrystals in Melamine Recognition}

Nanocrystals are one of the modern candidates utilized in various analytical studies. For example, rare earth phosphate crystal decorated with Au NPs was reported by Chen et al. as a probe for the detection of biological aminothiols [95]. Mahalingam and co-workers presented the melamine sensing ability of 3,5-dinitrobenzoic acid (DNB)-capped up-conversion nanocrystals as described in Reference [96]. Wherein, $\mathrm{DNB}$ capped $\mathrm{Er} / \mathrm{Yb}-\mathrm{NaYF}_{4}$ nanocrystals were investigated in melamine assay via quenching of emission as illustrated in Figure 15. The emission was restored upon the addition of 
dilute acid. The detection limit by this method is remarkable and is estimated to be $2.5 \mathrm{nM}$. Hence it can be applied in real-time screening of melamine. Towards this exceptional efficient nanocrystals-based sensing approach, much contributions are required from other researchers.

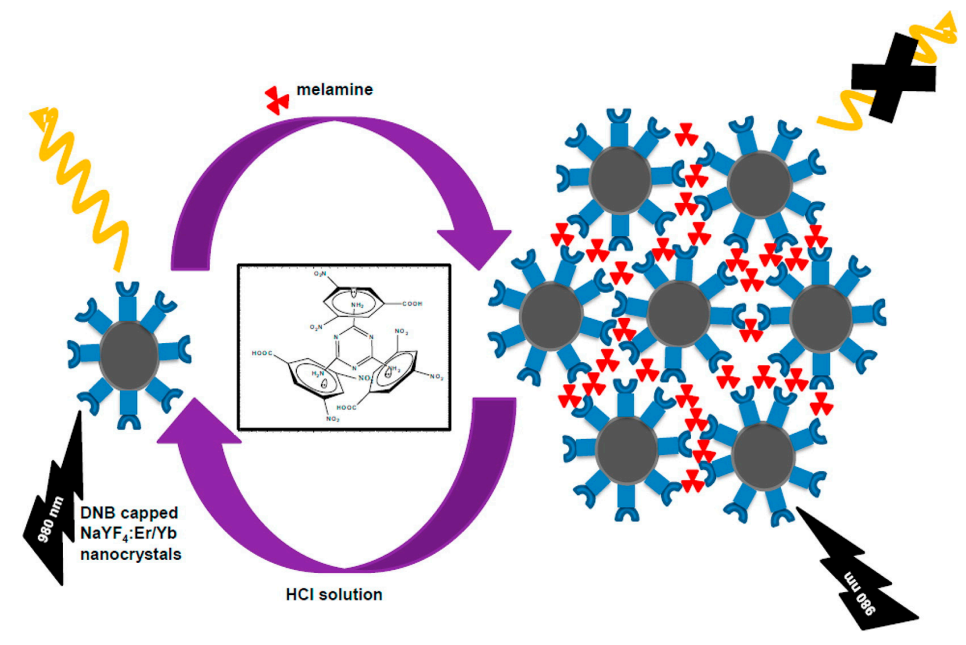

Figure 15. Scheme illustrating the interaction of melamine with 3,5-dinitrobenzoic acid (DNB) -capped $\mathrm{NaYF}_{4}: \mathrm{Er}^{3+} / \mathrm{Yb}^{3+}$ nanocrystals (reproduced with permission from Reference [96]).

\section{Nanoparticles in Melamine Quantification}

Nanoparticles-based sensing approaches have become the modern research towards diverse analyte determination. Studies on the Ag NPs and Au NPs colorimetric sensors are particularly impressive [97]. For example, Cao's report described the Au NPs-based melamine assay as a suitable kit in various milk products [98]. They engaged the $5 \mathrm{~nm}$ Au NPs which were fabricated through sodium borohydride reduction and applied them towards the effective assay of melamine. Notably, this kit operated between the melamine concentrations of $7.93 \mu \mathrm{M}$ to $0.95 \mathrm{mM}$ with a LOD of $7.93 \mu \mathrm{M}$. The detection work can be completed within $10 \mathrm{~min}$. However, various Au NPs-based rapid detection probes were also reported as described next. Li's group demonstrated the naked-eye visual detection process towards melamine recognition via peroxidase-like activity of bare Au NPs with the support of 3,3',5,5'-tetramethlybenzidine (TMB) $-\mathrm{H}_{2} \mathrm{O}_{2}$ [99]. In this approach, the LOD of melamine by naked eye was established as $0.5 \mu \mathrm{M}$ and the LOD was fixed to be $0.2 \mathrm{nM}$ through standard deviation. The above method displays excellent recoveries and RSDs in spiked samples with the linearity ranged from 1 to $800 \mathrm{nM}$.

Chen et al. reported the bare gold nanoparticles as a probe for colorimetric discovery of melamine [100]. Similar to the above method, various label free or citrate-stabilized Au NPs with diverse sizes were reported in melamine discrimination [101-116]. Similarly, many capped or stabilized $\mathrm{Au}$ NPs were testified in melamine identification. Table 1 summarizes the detection methods, instruments employed, optimization status, time required for analyses, linear ranges, LODs, recoveries in spiked samples, and RSDs of those probes utilized so far in melamine analysis [98-166]. Information on instruments, optimization status, and time will determine the effectiveness and probable cost of the projected tactics, which provides helps for the future research. Surprisingly, most of these $\mathrm{Au}$ NPs-based probes detect the melamine adulteration via colorimetric responses. Only a few of them detect the melamine adulteration through SERS, fluorescence, light scattering, mass/ionization, peroxidase activity, and sonoluminescence techniques, etc. The majority of the label-free, unmodified or citrate-stabilized Au NPs detect melamine via aggregation of particles as shown in Figure 16. However, the LODs can be improved by changing the size of the Au NPs [105,115].

On the other end of the spectrum, $\mathrm{Lu}$ et al. presented the $\mathrm{Au}$ NPs-based fluorescent "turn-on" detection of melamine via mixing Au NPs with an organic probe [114]. Following this direction, diverse functional units stabilized Au NPs have been developed and exploited 
in melamine discovery through colorimetric, SERS, FRET, CRET, U-Vis, light scattering, test strip, capillary electrophoresis, and fluorescence studies [98-166]. The mainstream of melamine sensing by functionalized Au NPs was attributed to H-bonding between stabilized Au NPs and melamine $[117,118,120,124,126-130]$. For example, Ai et al. developed the thiol containing cysteamine derivative "1-(2-mercaptoethyl)-1,3,5-triazinane-2,4,6-trione (MTT)" functionalized Au NPs which displayed the H-bonding mediated sensing of melamine [117] as illustrated in Figure 17. So far, many H-bond facilitated assays of melamine have been reported, which has led to saturation of this research strategy. Therefore, to further extend the Au NPs-based on-site melamine assay, collaboration from other research fields-such as opto-electronic techniques-is required.

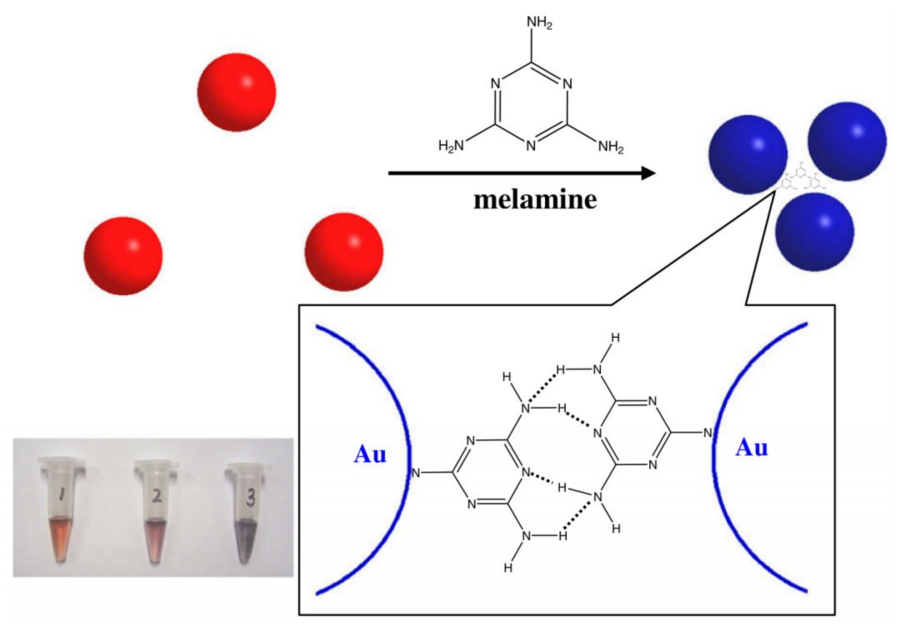

Figure 16. Schematic representation of the GNPs colorimetric mechanism for melamine detection. The insert is photographs of solution of (1) $400 \mu \mathrm{L} \mathrm{GNPs}+20 \mu \mathrm{L} \mathrm{H} \mathrm{H}_{2} \mathrm{O}$, (2) $400 \mu \mathrm{L}$ GNPs $+20 \mu \mathrm{L}$ melamine $\left(5 \times 10^{-3} \mathrm{~g} / \mathrm{L}\right)$, and (3) $400 \mu \mathrm{L} \mathrm{GNPs}+20 \mu \mathrm{L}$ melamine $\left(20 \times 10^{-3} \mathrm{~g} / \mathrm{L}\right)$. Experimental condition: GNPs, $1.4 \mu \mathrm{M}$; incubation time, $1 \mathrm{~min}$; reaction temperature, room temperature $\left(\sim 20^{\circ} \mathrm{C}\right)$.

A

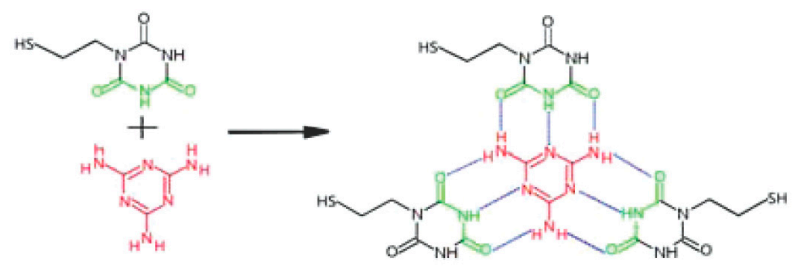

B

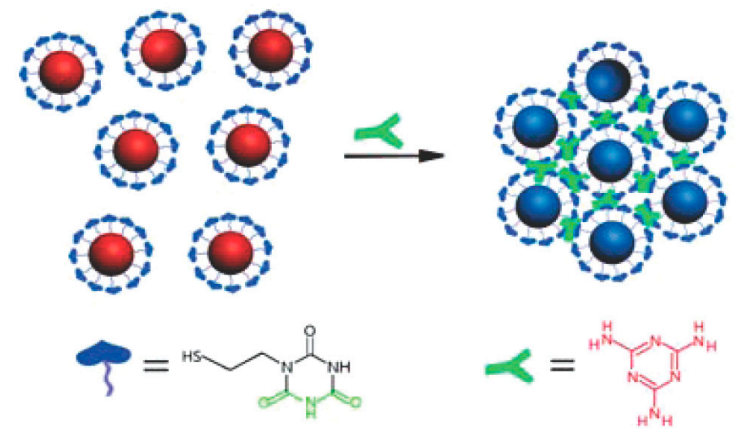

Figure 17. (A) Hydrogen-bonding recognition between melamine and cyanuric acid derivative. (B) Colorimetric detection of melamine using the 1-(2-mercaptoethyl)-1,3,5-triazinane-2,4,6-trione (MTT)-stabilized gold nanoparticles (reproduced with permission from Reference [117]). 
Table 1. Summary of methods, instruments, optimization status, time, linear ranges, detection limits (LODs), recoveries and relative standard deviations (RSDs) of Au NPs-based probes in melamine detection.

\begin{tabular}{|c|c|c|c|c|c|c|c|c|}
\hline $\begin{array}{c}\text { Au NPs-Based } \\
\text { Probe }\end{array}$ & $\begin{array}{l}\text { Method of } \\
\text { Detection }\end{array}$ & $\begin{array}{l}\text { Instruments } \\
\text { Employed }\end{array}$ & $\begin{array}{c}\text { Optimization Status and } \\
\text { Time Required }\end{array}$ & Linear Range & LOD & $\begin{array}{c}\text { Recoveries of } \\
\text { Spiked Samples }\end{array}$ & RSDs & Ref. \\
\hline Bare Au NPs & Colorimetric & $\begin{array}{l}\text { Naked eyes and UV-Vis } \\
\text { spectrometer }\end{array}$ & Complicated and $10 \mathrm{~min}$ & $7.93 \mu \mathrm{M}-0.95 \mathrm{mM}$ & $7.93 \mu \mathrm{M}$ & NA & NA & [98] \\
\hline Bare Au NPs & $\begin{array}{l}\text { Colorimetric } \\
\text { (peroxidase-like } \\
\text { activity) }\end{array}$ & $\begin{array}{l}\text { Naked eyes and UV-Vis } \\
\text { spectrometer }\end{array}$ & Complicated and $30 \mathrm{~min}$ & $1-800 \mathrm{nM}$ & $0.2 \mathrm{nM}$ & $94.55-120.50 \%$ & $0.07-0.99 \%$ & [99] \\
\hline Bare Au NPs & Colorimetric & $\begin{array}{l}\text { Naked eyes and UV-Vis } \\
\text { spectrometer }\end{array}$ & Moderate and $7 \mathrm{~min}$ & $39.64 \mathrm{nM}-1.59 \mu \mathrm{M}$ & $1.59 \mathrm{nM}$ & $97.6-107 \%$ & $0.8-2.4 \%$ & {$[100]$} \\
\hline $\begin{array}{l}\text { Citrate-stabilized } \\
\text { Au NPs }\end{array}$ & Colorimetric & $\begin{array}{l}\text { Naked eyes and UV-Vis } \\
\text { spectrometer }\end{array}$ & Moderate and $20 \mathrm{~min}$ & $0-634 \mu \mathrm{M}$ & $19.8 \mu \mathrm{M}$ & NA & NA & [101] \\
\hline $\begin{array}{c}\text { Citrate-stabilized } \\
\text { Au NPs }\end{array}$ & Colorimetric & $\begin{array}{l}\text { Naked eyes and UV-Vis } \\
\text { spectrometer }\end{array}$ & Moderate and 2 min & $0-1.9 \mu \mathrm{M}$ & $198 \mathrm{nM}$ & NA & NA & [102] \\
\hline Label free Au NPs & Colorimetric & $\begin{array}{l}\text { Naked eyes and UV-Vis } \\
\text { spectrometer }\end{array}$ & Moderate and $12 \mathrm{~min}$ & $1.59-79.3 \mu \mathrm{M}$ & $3.2 \mu \mathrm{M}$ & $97-105 \%$ & $0-2 \%$ & [103] \\
\hline $\begin{array}{c}\text { Citrate-stabilized } \\
\text { Au NPs }\end{array}$ & Fluorescent & $\begin{array}{l}\text { UV-Vis and PL } \\
\text { spectrometer }\end{array}$ & Moderate and NA & $0.8-80 \mathrm{nM}$ & $0.61 \mathrm{nM}$ & $97.92-98.54 \%$ & NA & [104] \\
\hline $\begin{array}{c}\text { Citrate-stabilized } \\
\text { Au NPs }\end{array}$ & Colorimetric & $\begin{array}{l}\text { Naked eyes and UV-Vis } \\
\text { spectrometer }\end{array}$ & Moderate and $1 \mathrm{~min}$ & NA & $39.64 \mathrm{nM}$ & NA & NA & [105] \\
\hline $\begin{array}{c}\text { Citrate-stabilized } \\
\text { Au NPs }\end{array}$ & Colorimetric & $\begin{array}{l}\text { Naked eyes and UV-Vis } \\
\text { spectrometer }\end{array}$ & Moderate and $10 \mathrm{~min}$ & $0.79-15.9 \mu \mathrm{M}$ & $0.4 \mu \mathrm{M}$ & $95-105 \%$ & $1.28-10.53 \%$ & [106] \\
\hline $\begin{array}{c}\text { Citrate-stabilized } \\
\text { Au NPs }\end{array}$ & Colorimetric & $\begin{array}{l}\text { Naked eyes and UV-Vis } \\
\text { spectrometer }\end{array}$ & Moderate and $15 \mathrm{~min}$ & $1.6-159 \mu \mathrm{M}$ & $15.86 \mu \mathrm{M}$ & $105-116 \%$ & NA & [107] \\
\hline $\begin{array}{c}\text { Citrate-stabilized } \\
\text { Au NPs }\end{array}$ & Colorimetric & $\begin{array}{l}\text { Naked eyes, DLS and } \\
\text { UV-Vis spectrometer }\end{array}$ & Complicated and NA & $1-100 \mu \mathrm{M}$ & $\begin{array}{c}33 \mathrm{nM}, 23.7 \mathrm{nM} \\
\text { and } 89 \mathrm{nM}\end{array}$ & $91-104 \%$ & $0.23-4.43 \%$ & [108] \\
\hline $\begin{array}{l}\text { Unmodified Au } \\
\text { NPs }\end{array}$ & Colorimetric & $\begin{array}{l}\text { Naked eyes and UV-Vis } \\
\text { spectrometer }\end{array}$ & Moderate and $>15 \mathrm{~min}$ & $0.95-3.9 \mu \mathrm{M}$ & $317 \mathrm{nM}$ & NA & NA & [110] \\
\hline $\begin{array}{l}\text { Unmodified Au } \\
\text { NPs }\end{array}$ & Colorimetric & $\begin{array}{l}\text { Naked eyes and UV-Vis } \\
\text { spectrometer }\end{array}$ & Moderate and NA & $0.79-79 \mu \mathrm{M}$ & $>3.2 \mu \mathrm{M}$ & NA & $\mathrm{NA}$ & [111] \\
\hline $\begin{array}{l}\text { Unmodified Au } \\
\text { NPs }\end{array}$ & Colorimetric & $\begin{array}{l}\text { Naked eyes and UV-Vis } \\
\text { spectrometer }\end{array}$ & Moderate and $20 \mathrm{~min}$ & $0-2 \mu \mathrm{M}$ & $555 \mathrm{nM}$ & $90-120 \%$ & NA & [112] \\
\hline $\begin{array}{l}\text { Unmodified Au } \\
\text { NPs }\end{array}$ & Colorimetric & $\begin{array}{l}\text { Naked eyes and UV-Vis } \\
\text { spectrometer }\end{array}$ & Moderate and NA & $\begin{array}{c}0.198-2.4 \mu \mathrm{M} \& \\
0.792-7.13 \mu \mathrm{M}\end{array}$ & $\begin{array}{c}182 \mathrm{nM} \text { and } 729 \\
\mathrm{nM}\end{array}$ & $97.5-101.1 \%$ & NA & [113] \\
\hline $\begin{array}{c}\text { Citrate-stabilizedAu } \\
\text { NPs }\end{array}$ & Fluorescent & PL spectrometer & Moderate and $>30 \mathrm{~min}$ & $10 \mathrm{nM}-4 \mu \mathrm{M}$ & $3 \mathrm{nM}$ & $92-108 \%$ & $0.80-4.21 \%$ & [114] \\
\hline $\begin{array}{c}\text { Citrate-stabilized-Au } \\
\text { NPs }\end{array}$ & Fluorescent & $\begin{array}{l}\text { DLS and PL } \\
\text { spectrometer }\end{array}$ & Complicated and $5 \mathrm{~min}$ & $40-700 \mathrm{nM}$ & $0.35 \mathrm{nM}$ & $97-100 \%$ & $2.1-4.28 \%$ & [115] \\
\hline $\begin{array}{c}\text { Citrate and } \\
\text { DNA-Au NPs }\end{array}$ & Colorimetric & $\begin{array}{l}\text { Naked eyes and UV-Vis } \\
\text { spectrometer }\end{array}$ & Moderate and $5 \mathrm{~min}$ & NA & $\begin{array}{l}41.7 \mathrm{nM} \text { amd } \\
\quad 46.5 \mathrm{nM}\end{array}$ & $82.9-102.6 \%$ & $0.80-2.06 \%$ & [116] \\
\hline
\end{tabular}


Table 1. Cont.

\begin{tabular}{|c|c|c|c|c|c|c|c|c|}
\hline $\begin{array}{l}\text { Au NPs-Based } \\
\text { Probe }\end{array}$ & $\begin{array}{l}\text { Method of } \\
\text { Detection }\end{array}$ & $\begin{array}{l}\text { Instruments } \\
\text { Employed }\end{array}$ & $\begin{array}{l}\text { Optimization Status and } \\
\text { Time Required }\end{array}$ & Linear Range & LOD & $\begin{array}{c}\text { Recoveries of } \\
\text { Spiked Samples }\end{array}$ & RSDs & Ref. \\
\hline $\begin{array}{l}\text { 1-(2-mercaptoethyl)- } \\
\text { 1,3,5-triazinane- } \\
\text { 2,4,6-trione (MTT)- } \\
\text { stabilizedAu NPs }\end{array}$ & Colorimetric & $\begin{array}{l}\text { Naked eyes and UV-Vis } \\
\text { spectrometer }\end{array}$ & Mild and $5 \mathrm{~min}$ & 7.93-39.64 $\mu \mathrm{M}$ & $19.82 \mathrm{nM}$ & NA & NA & [117] \\
\hline $\begin{array}{c}\text { Hexadecy } \\
\text { ltrimethyl } \\
\text { ammonium } \\
\text { chloride } \\
\text { (CTAC)-stabilized } \\
\text { Au NPs }\end{array}$ & Colorimetric & $\begin{array}{l}\text { Naked eyes and UV-Vis } \\
\text { spectrometer }\end{array}$ & Moderate and $50 \mathrm{~min}$ & $1 \mathrm{nM}-10 \mu \mathrm{M}$ & $0.8 \mathrm{nM}$ & NA & NA & [118] \\
\hline $\begin{array}{c}\text { 11-Mercapto- } \\
\text { undecanoic acid } \\
\text { (MUA)-stabilized } \\
\text { Au NPs }\end{array}$ & $\begin{array}{c}\text { Capillary } \\
\text { electrophoresis-UV }\end{array}$ & $\begin{array}{l}\text { Naked eyes and UV } \\
\text { absorbance detector }\end{array}$ & Complicated and $90 \mathrm{~min}$ & $1-1000 \mathrm{nM}$ & $77 \mathrm{pM}$ & $\begin{array}{c}97-101 \% \text { and } \\
95-99 \%\end{array}$ & NA & [119] \\
\hline $\begin{array}{l}\text { Polythymine (Poly } \\
T_{\mathbf{n}} \text { )-stabilized Au } \\
\text { NPs }\end{array}$ & Colorimetric & $\begin{array}{l}\text { Naked eyes, DLS and } \\
\text { UV-Vis spectrometer }\end{array}$ & Moderate and $30 \mathrm{~min}$ & $80-1000 \mathrm{nM}$ & $20 \mathrm{nM}$ & NA & NA & [120] \\
\hline $\begin{array}{c}\text { 18-crown-6Ether- } \\
\text { functionalized Au } \\
\text { NPs }\end{array}$ & Colorimetric & $\begin{array}{l}\text { Naked eyes and UV-Vis } \\
\text { spectrometer }\end{array}$ & Moderate and $>1 \mathrm{~min}$ & $79.3 \mathrm{nM}-3.96 \mu \mathrm{M}$ & $47.57 \mathrm{nM}$ & $98.4-105.6 \%$ & $1.7-5.8 \%$ & [121] \\
\hline $\begin{array}{l}\text { Cysteamine-modified } \\
\text { Au NPs }\end{array}$ & Colorimetric & $\begin{array}{l}\text { Naked eyes and UV-Vis } \\
\text { spectrometer }\end{array}$ & Moderate and $>30 \mathrm{~min}$ & $7.92 \mu \mathrm{M}-1.59 \mathrm{mM}$ & $7.92 \mu \mathrm{M}$ & NA & $\mathrm{NA}$ & [122] \\
\hline $\begin{array}{l}\text { Citrate-stabilized } \\
\text { Au NPs with } \\
\text { Fluorescein }\end{array}$ & FRET & PL spectrometer & Moderate and $>12 \mathrm{~min}$ & $0.1 \mu \mathrm{M}-4 \mu \mathrm{M}$ & $1 \mathrm{nM}$ & NA & NA & [123] \\
\hline $\begin{array}{c}\text { 3-mercapto-1-propane } \\
\text {-sulfonate-modifiedAu } \\
\text { NPs }\end{array}$ & Colorimetric & $\begin{array}{l}\text { Naked eyes and UV-Vis } \\
\text { spectrometer }\end{array}$ & Moderate and $30 \mathrm{~min}$ & $\begin{array}{l}10-150 \mathrm{nM} \& \\
150-600 \mathrm{nM}\end{array}$ & $8 \mathrm{nM}$ & $\begin{array}{l}98.0-104.5 \% \\
93.6-101.6 \%\end{array}$ & $\begin{array}{l}1.6-3.7 \% \\
\text { and } \\
3.9-5.9 \%\end{array}$ & [124] \\
\hline $\begin{array}{l}\text { 4-mercaptopyridine- } \\
\text { modified Au NPs }\end{array}$ & SERS & $\begin{array}{l}\text { UV-Vis and Raman } \\
\text { spectrometer }\end{array}$ & Moderate and $>0.5 \mathrm{~min}$ & $3.96-793 \mathrm{nM}$ & $793 \mathrm{pM}$ & $88.5-119.2 \%$ & NA & [125] \\
\hline $\begin{array}{l}\text { pyrocatechol-3,5- } \\
\text { disodiumsulfonate- } \\
\text { stabilized Au NPs }\end{array}$ & Colorimetric & $\begin{array}{l}\text { Naked eyes and UV-Vis } \\
\text { spectrometer }\end{array}$ & Moderate and $80 \mathrm{~min}$ & $4.8 \mathrm{nM}-1.6 \mu \mathrm{M}$ & $0.64 \mathrm{nM}$ & $93-107 \%$ & NA & [126] \\
\hline $\begin{array}{l}\text { ssDNA-stabilized } \\
\text { Au NPs }\end{array}$ & $\begin{array}{l}\text { Resonance } \\
\text { Rayleigh } \\
\text { Scattering (RRS) } \\
\text { and Cat RRS }\end{array}$ & $\begin{array}{l}\text { Eclipse fluorescence } \\
\text { spectro-photometer }\end{array}$ & Moderate and $>30 \mathrm{~min}$ & $\begin{array}{c}15-650 \mathrm{nM} \text { and } \\
5-38 \mathrm{pM}\end{array}$ & 7.8 and $3 \mathrm{pM}$ & $99.2-100 \%$ & $0.8-1.7 \%$ & [128] \\
\hline $\begin{array}{l}\text { Thioglycolic-Acid- } \\
\text { Modified Au NPs }\end{array}$ & Colorimetric & $\begin{array}{l}\text { Naked eyes and UV-Vis } \\
\text { spectrometer }\end{array}$ & Moderate and $>15 \mathrm{~min}$ & $0-19.66 \mu \mathrm{M}$ & NA & $101.1-102 \%$ & $1.6-2.3 \%$ & [129] \\
\hline
\end{tabular}


Table 1. Cont.

\begin{tabular}{|c|c|c|c|c|c|c|c|c|}
\hline $\begin{array}{l}\text { Au NPs-Based } \\
\text { Probe }\end{array}$ & $\begin{array}{l}\text { Method of } \\
\text { Detection }\end{array}$ & $\begin{array}{l}\text { Instruments } \\
\text { Employed }\end{array}$ & $\begin{array}{l}\text { Optimization Status and } \\
\text { Time Required }\end{array}$ & Linear Range & LOD & $\begin{array}{c}\text { Recoveries of } \\
\text { Spiked Samples }\end{array}$ & RSDs & Ref. \\
\hline $\begin{array}{l}\text { 2,4,6-trinitrobenzene- } \\
\text { sulfonic acid (TNBS) } \\
\text { tailored Au NPs }\end{array}$ & Colorimetric & $\begin{array}{l}\text { Naked eyes and UV-Vis } \\
\text { spectrometer }\end{array}$ & Moderate and $>10 \mathrm{~min}$ & $0-634 \mathrm{nM}$ & $39.64 \mathrm{nM}$ & NA & NA & [130] \\
\hline $\begin{array}{l}\text { Citrate-stabilized } \\
\text { Au NPs }\end{array}$ & Strip method & $\begin{array}{l}\text { immuno-chromatographic } \\
\text { strip analyzer }\end{array}$ & Complicated and NA & $23.8-99 \mathrm{nM}$ & $35.4 \mathrm{nM}$ & NA & NA & [131] \\
\hline $\begin{array}{c}\text { Pyridine-3-Boronic } \\
\text { Acid-modified Au } \\
\text { NPs }\end{array}$ & Colorimetric & $\begin{array}{l}\text { Naked eyes and UV-Vis } \\
\text { spectrometer }\end{array}$ & Moderate and $>20 \mathrm{~min}$ & $60 \mathrm{nM}-1.6 \mu \mathrm{M}$ & $30 \mathrm{nM}$ & $95-102 \%$ & NA & [132] \\
\hline Bare Au NPs & SERS & Raman spectrometer & Complicated and $>15 \mathrm{~min}$ & $1.6-159 \mu \mathrm{M}$ & $3.1 \mu \mathrm{M}$ & $95-109 \%$ & $0.77-4.21 \%$ & [133] \\
\hline $\begin{array}{c}\text { 3-amino-5-mercapto- } \\
\text { 1,2,4-triazole-capped } \\
\text { Au NPs }\end{array}$ & $\begin{array}{l}\text { Colorimetric \& } \\
\text { Fluorimetry }\end{array}$ & $\begin{array}{l}\text { Naked eyes, UV-Vis } \\
\text { and PL spectrometer }\end{array}$ & Moderate and NA & $0.1-1 \mathrm{nM}$ & $10 \mathrm{fM}$ & NA & NA & {$[134]$} \\
\hline $\begin{array}{l}\text { ssDNA-modified } \\
\text { Au NPs }\end{array}$ & Colorimetric & $\begin{array}{l}\text { Naked eyes and UV-Vis } \\
\text { spectrometer }\end{array}$ & Moderate and $40 \mathrm{~min}$ & $0.1-1.0 \mu \mathrm{M}$ & $34 \mathrm{nM}$ & $94-120 \%$ & NA & [135] \\
\hline $\begin{array}{l}\text { Cysteamine-modified } \\
\text { Au NPsdified }\end{array}$ & Colorimetric & $\begin{array}{l}\text { Naked eyes and UV-Vis } \\
\text { spectrometer }\end{array}$ & Moderate and $45 \mathrm{~min}$ & $0.08-1.6 \mu \mathrm{M}$ & $80 \mathrm{nM}$ & $98-102 \%$ & $1.7-2.6 \%$ & [136] \\
\hline $\begin{array}{l}\text { Au NPs synthesized } \\
\text { by ellagic acid (EA) }\end{array}$ & Colorimetric & $\begin{array}{l}\text { Naked eyes and UV-Vis } \\
\text { spectrometer }\end{array}$ & Mild and $30 \mathrm{~min}$ & $16 \mathrm{nM}-160 \mu \mathrm{M}$ & $1.6 \mathrm{nM}$ & $93-106 \%$ & NA & [137] \\
\hline $\begin{array}{l}\text { Aptamer-modified } \\
\text { Au NPs }\end{array}$ & Colorimetric & $\begin{array}{l}\text { Naked eyes and UV-Vis } \\
\text { spectrometer }\end{array}$ & Moderate and $30 \mathrm{~min}$ & $\begin{array}{c}1.2-2.4 \mu \mathrm{M} \text { and } \\
2.4-20.62 \mu \mathrm{M}\end{array}$ & $793 \mathrm{nM}$ & $95-105 \%$ & $3.9 \%$ & [138] \\
\hline $\begin{array}{c}\text { Citrate-stabilized } \\
\text { Au NPs }\end{array}$ & $\begin{array}{l}\text { Chemiluminescence } \\
\text { resonance } \\
\text { energy transfer } \\
\text { (CRET) }\end{array}$ & $\begin{array}{l}\text { Chemiluminescence } \\
\text { analyzer, PL and } \\
\text { UV-Vis spectrometer }\end{array}$ & Mild and $45 \mathrm{~min}$ & $3.2 \mathrm{pM}-0.32 \mu \mathrm{M}$ & $0.3 \mathrm{pM}$ & $94.1-104.2 \%$ & $1.5-4.5 \%$ & [139] \\
\hline $\begin{array}{l}\text { p-DNA-modified } \\
\text { Au NPs }\end{array}$ & $\begin{array}{c}\text { Colorimetric } \\
\text { and Dynamic } \\
\text { Light Scattering } \\
\text { (DLS) }\end{array}$ & $\begin{array}{l}\text { Naked eyes, DLS and } \\
\text { UV-Vis spectrometer }\end{array}$ & Moderate and $>3 \mathrm{~min}$ & $39.64 \mathrm{nM}-2.54 \mu \mathrm{M}$ & $15.9 \mathrm{nM}$ & NA & NA & [140] \\
\hline $\begin{array}{c}\text { Citrate and } \\
\text { dodecasodium salt } \\
\text { of phytic acid } \\
\text { functionalized Au } \\
\text { NPs }\end{array}$ & SERS & Raman spectrometer & Moderate \& $90 \mathrm{~min}$ & $10-100 \mu \mathrm{M}$ & $5 \mu \mathrm{M}$ & $93.6 \%$ & NA & [141] \\
\hline $\begin{array}{c}\text { 3-Mercapto-propionic } \\
\text { acid functionalized } \\
\text { Au NPs }\end{array}$ & Colorimetric & $\begin{array}{l}\text { Naked eyes and UV-Vis } \\
\text { spectrometer }\end{array}$ & Moderate \& $10 \mathrm{~min}$ & $4.8-333 \mathrm{nM}$ & $3.2 \mathrm{nM}$ & $96-105 \%$ & NA & [142] \\
\hline $\begin{array}{l}\text { Citrate stabilized } \\
\text { Au NPs with } \\
\text { Rhodamine B }\end{array}$ & FRET & $\begin{array}{l}\text { PL and UV-Vis } \\
\text { spectrometer }\end{array}$ & Moderate \& $>40 \mathrm{~min}$ & $39.64 \mathrm{nM}-7.93 \mu \mathrm{M}$ & $1.43 \mathrm{nM}$ & $95.9-102.2 \%$ & $0.8-3.0 \%$ & [143] \\
\hline $\begin{array}{c}\text { Rhodamine B } \\
\text { Acetylated } \\
\text { chitosan-stabilized } \\
\text { Au NPs }\end{array}$ & Colorimetric & $\begin{array}{l}\text { Naked eyes, CV and } \\
\text { UV-Vis spectrometer }\end{array}$ & Moderate \& NA & $396 \mathrm{nM}-7.93 \mu \mathrm{M}$ & $389 \mathrm{nM}$ & $94-111 \%$ & NA & [144] \\
\hline
\end{tabular}


Table 1. Cont.

\begin{tabular}{|c|c|c|c|c|c|c|c|c|}
\hline $\begin{array}{l}\text { Au NPs-Based } \\
\text { Probe }\end{array}$ & $\begin{array}{l}\text { Method of } \\
\text { Detection }\end{array}$ & $\begin{array}{l}\text { Instruments } \\
\text { Employed }\end{array}$ & $\begin{array}{l}\text { Optimization Status and } \\
\text { Time Required }\end{array}$ & Linear Range & LOD & $\begin{array}{c}\text { Recoveries of } \\
\text { Spiked Samples }\end{array}$ & RSDs & Ref. \\
\hline $\begin{array}{c}\text { 1,4-dithiothreitol } \\
\text {-modified (DTT) Au } \\
\text { NPs }\end{array}$ & Colorimetric & $\begin{array}{l}\text { Naked eyes and UV-Vis } \\
\text { spectrometer }\end{array}$ & Moderate and $5 \mathrm{~min}$ & $80 \mathrm{nM}-1.5 \mu \mathrm{M}$ & $24 \mathrm{nM}$ & $96-103 \%$ & NA & [145] \\
\hline $\begin{array}{l}\text { Au NPs synthesized } \\
\text { by Methanobactin } \\
(\mathrm{Mb})\end{array}$ & Colorimetric & $\begin{array}{l}\text { Naked eyes and UV-Vis } \\
\text { spectrometer }\end{array}$ & Moderate and $50 \mathrm{~min}$ & $0.39-3.97 \mu \mathrm{M}$ & $0.238 \mu \mathrm{M}$ & $97.5-103.1 \%$ & $0.8 \%$ & [146] \\
\hline $\begin{array}{l}\text { Thymine derivative- } \\
\text { functionalized Au } \\
\text { NPs }\end{array}$ & Colorimetric & $\begin{array}{l}\text { Naked eyes and UV-Vis } \\
\text { spectrometer }\end{array}$ & Moderate and $10 \mathrm{~min}$ & $0.75-5.00 \mu \mathrm{M}$ & $3.5 \mathrm{nM}$ & $96.5-102.0 \%$ & $4.0-11.8 \%$ & [147] \\
\hline $\mathrm{H}_{2} \mathrm{O}_{2}-\mathrm{Au} \mathrm{NPs}$ & Colorimetric & $\begin{array}{l}\text { Naked eyes and UV-Vis } \\
\text { spectrometer }\end{array}$ & Moderate and $35 \mathrm{~min}$ & $0.4-160 \mu \mathrm{M}$ & $0.078 \mu \mathrm{M}$ & $90-113.7 \%$ & NA & [148] \\
\hline $\begin{array}{c}\text { Up-conversion } \\
\text { nanoparticles } \\
\text { (UCNPs) and } \mathrm{Au} \\
\text { NPs }\end{array}$ & FRET & PL spectrometer & Moderate and $12 \mathrm{~min}$ & $32-500 \mathrm{nM}$ & $18 \mathrm{nM}$ & $98.8-102 \%$ & $2.32-4.44 \%$ & [149] \\
\hline $\begin{array}{l}\text { Citrate-stabilized } \\
\text { Au NPs }\end{array}$ & $\begin{array}{l}\text { Fluorescent and } \\
\text { UV-Vis }\end{array}$ & $\begin{array}{l}\text { UV-Vis and PL } \\
\text { spectrometer }\end{array}$ & Complicated and $60 \mathrm{~min}$ & $0.4-2 \mu \mathrm{M}$ & $0.88 \mu \mathrm{M}$ & NA & NA & {$[150]$} \\
\hline $\begin{array}{c}\text { Polythymine }(\mathrm{T}) \\
\text { aptamer -modified } \\
\text { Au NPs }\end{array}$ & SERS & Raman spectrometer & Complicated and NA & $0-31.7 \mathrm{fM}$ & $7.9 \mathrm{fM}$ & $97.3-109.53 \%$ & NA & [151] \\
\hline $\begin{array}{c}p \text {-chlorobenzenesulfonic } \\
\text { acid-modified Au } \\
\text { NPs }\end{array}$ & ic Colorimetric & $\begin{array}{l}\text { Naked eyes and UV-Vis } \\
\text { spectrometer }\end{array}$ & Moderate and $15 \mathrm{~min}$ & $0.6-1.5 \mu \mathrm{M}$ & $2.3 \mathrm{nM}$ & $97.9-103 \%$ & $0.1-6.5 \%$ & [152] \\
\hline $\begin{array}{l}\text { BSA conjugated Au } \\
\text { NPs }\end{array}$ & Colorimetric & $\begin{array}{l}\text { Signal amplified lateral } \\
\text { flow strip }\end{array}$ & Complicated and NA & $7.93 \mathrm{nM}-1.59 \mu \mathrm{M}$ & $11.1 \mathrm{nM}$ & NA & NA & [153] \\
\hline $\begin{array}{l}\text { Unmodified Au } \\
\text { NPs }\end{array}$ & Colorimetric & $\begin{array}{l}\text { Naked eyes and UV-Vis } \\
\text { spectrometer }\end{array}$ & Moderate and $30 \mathrm{~min}$ & $0-0.9 \mu \mathrm{M}$ & $33 \mathrm{nM}$ & $99.2-111 \%$ & $0.56-1.91 \%$ & [154] \\
\hline $\begin{array}{l}\text { Cysteamine-stabilized } \\
\text { Au NPs } \\
\text { amine-ended dual }\end{array}$ & Colorimetric & $\begin{array}{l}\text { Naked eyes and UV-Vis } \\
\text { spectrometer }\end{array}$ & Moderate and 6 min & $1-24 \mathrm{nM}$ & $0.389 \mathrm{nM}$ & $92.8-112.2 \%$ & NA & [155] \\
\hline $\begin{array}{l}\text { amine-enaed aual } \\
\text { thiol ligand } \\
\text { functionalized } \\
\text { Au NPs }\end{array}$ & Colorimetric & $\begin{array}{l}\text { Naked eyes and UV-Vis } \\
\text { spectrometer }\end{array}$ & Complicated and NA & NA & NA & NA & NA & [156] \\
\hline $\begin{array}{c}\text { Cellulose-coated Au } \\
\text { NPs }\end{array}$ & SERS & Raman spectrometer & Moderate and $15 \mathrm{~min}$ & $0-79.3 \mu \mathrm{M}$ & $7.93 \mu \mathrm{M}$ & $87.6-92.3 \%$ & NA & [157] \\
\hline $\begin{array}{c}\text { Triton } \\
\text { X-100-modifiedAu } \\
\text { NPs }\end{array}$ & Colorimetric & $\begin{array}{l}\text { Naked eyes and UV-Vis } \\
\text { spectrometer }\end{array}$ & Moderate and NA & $0.75-1.75 \mu \mathrm{M}$ & $5.1 \mathrm{nM}$ & $99-111 \%$ & $0.73-2.91 \%$ & [158] \\
\hline $\begin{array}{c}\text { uracil } \\
\text { 5'-triphosphate } \\
\text { sodium-modified } \\
\text { Au NPs }\end{array}$ & $\begin{array}{l}\text { Colorimetric } \\
\text { and light } \\
\text { scattering }\end{array}$ & $\begin{array}{l}\text { Naked eyes, DLS and } \\
\text { UV-Vis spectrometer }\end{array}$ & Moderate and $30 \mathrm{~min}$ & $\begin{array}{l}300-900 \mathrm{nM} \text { and } \\
200-950 \mathrm{nM}\end{array}$ & NA & $98.5-104 \%$ & $3.6-4.6 \%$ & [159] \\
\hline
\end{tabular}


Table 1. Cont.

\begin{tabular}{|c|c|c|c|c|c|c|c|c|}
\hline $\begin{array}{c}\text { Au NPs-Based } \\
\text { Probe }\end{array}$ & $\begin{array}{l}\text { Method of } \\
\text { Detection }\end{array}$ & $\begin{array}{l}\text { Instruments } \\
\text { Employed }\end{array}$ & $\begin{array}{c}\text { Optimization Status and } \\
\text { Time Required }\end{array}$ & Linear Range & LOD & $\begin{array}{c}\text { Recoveries of } \\
\text { Spiked Samples }\end{array}$ & RSDs & Ref. \\
\hline $\begin{array}{c}\text { Citrate-stabilized } \\
\text { Au NPs }\end{array}$ & SERS & $\begin{array}{l}\text { UV-Vis and Raman } \\
\text { spectrometer }\end{array}$ & Moderate and $10 \mathrm{~min}$ & $0-1.59 \mu \mathrm{M}$ & $793 \mathrm{nM}$ & NA & NA & [160] \\
\hline $\begin{array}{l}\text { Unmodified Au } \\
\text { NPs }\end{array}$ & SERS & Raman spectrometer & NA & $0-79.3 \mu \mathrm{M}$ & $793 \mathrm{nM}$ & NA & NA & [161] \\
\hline $\begin{array}{c}\text { Citrate stabilized } \\
\text { Au NPs }\end{array}$ & SERS & Raman spectrometer & Moderate and $>30 \mathrm{~min}$ & $2.5-39.64 \mu \mathrm{M}$ & $1.35 \mu \mathrm{M}$ & $96.3-99.9 \%$ & $3.8-9.6 \%$ & [162] \\
\hline $\begin{array}{l}\text { Citrate stabilized } \\
\text { Au NPs }\end{array}$ & $\begin{array}{l}\text { Colorimetric \& } \\
\text { SERS }\end{array}$ & $\begin{array}{l}\text { Naked eyes and Raman } \\
\text { spectrometer }\end{array}$ & Moderate and $20 \mathrm{~min}$ & $0-1.98 \mu \mathrm{M}$ & NA & NA & NA & [163] \\
\hline $\begin{array}{l}\text { Citrate stabilized } \\
\text { Au NPs }\end{array}$ & Mass Analysis & $\begin{array}{l}\text { surface-assisted laser } \\
\text { desorption/ionization } \\
\text { mass spectrometer }\end{array}$ & $\begin{array}{l}\text { Complicated and } \\
>0.5 \mathrm{~min}\end{array}$ & NA & NA & NA & NA & [164] \\
\hline $\begin{array}{l}\text { Citrate stabilized } \\
\text { Au NPs }\end{array}$ & Sonoluminescence & $\begin{array}{c}\text { Sonoluminescence } \\
\text { analyzer }\end{array}$ & Moderate and $>12 \mathrm{~min}$ & $10-240 \mathrm{nM}$ & $3 \mathrm{nM}$ & $95 \%$ & NA & [165] \\
\hline $\begin{array}{c}\mathrm{SiO}_{2} \text { shell-isolated } \\
\mathrm{Au} \mathrm{NPs}\end{array}$ & SERS & $\begin{array}{l}\text { UV-Vis and Raman } \\
\text { spectrometer }\end{array}$ & Moderate and $>6 \mathrm{~min}$ & $3.96-39.64 \mu \mathrm{M}$ & $7.93 \mu \mathrm{M}$ & $94.6-102.5 \%$ & $5.4-9.5 \%$ & [166] \\
\hline
\end{tabular}

$\mathrm{NA}=$ Not available $; \mathrm{mM}=$ millimole $; \mu \mathrm{M}=$ micromole; $\mathrm{nM}=$ nanomole; $\mathrm{pM}=$ picomole; $\mathrm{fM}=$ femtomole $;$ min = minutes . 
Chang and co-workers presented the assay of melamine through UV-Vis followed by capillary electrophoresis [119]. They demonstrated the 11-mercaptoundecanoic acid-capped gold nanoparticles (MUA-AuNPs) which recognized melamine via aggregation of Au NPs. The dithiothreitol (DTT) was used to extract the melamine from the supernatant through capillary electrophoresis. This method can be validated as a suitable detection and extraction technique for melamine present in dairy products and food products. However, optimization of the above technique is most likely to be complicated, and hence real-time reliability is still in question. Likewise, a complex, which performs melamine recognition, is realized by 18-crown-6-ether-functionalized Au NPs and methanobactin mediated $\mathrm{Au}$ NPs synthesize $[121,146]$. The effective melamine detection is demonstrated by 18-crown-6-ether-functionalized Au NPs via complex formation as illustrated in Figure 18.

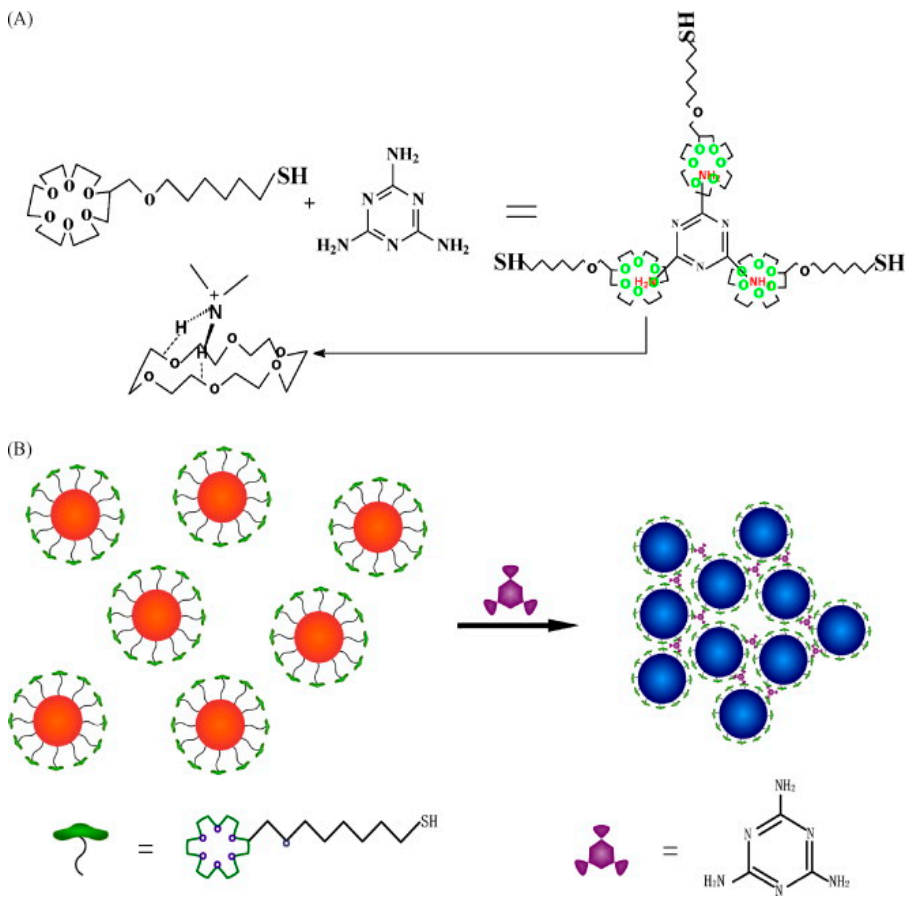

Figure 18. Schematics of the melamine sensing with 18-crown-6-thiol-modified GNPs. (A) Specific interaction in the complex between the crown ether and melamine; (B) melamine-induced aggregation of 18-crown-6-thiol-modified GNPs (reproduced with permission from Reference [121]).

Aggregation and electrostatic forces involved tactics were also described by a few reports $[122,134,144,154,158]$. However, these methodologies still require more attention. On the other hand, a few researchers have attempted to utilize the Au NPs-based probes towards melamine quantification by fluorescence resonance energy transfer (FRET) and chemiluminescence resonance energy transfer (CRET), which may possibly demonstrate the effective assay of melamine in the near future $[123,139,143,149]$. Besides, SERS-based detection of melamine has also been authenticated as a more efficient tactic. Many researchers reported the functionalized or label free or bare $\mathrm{Au}$ NPs towards the discrimination of melamine through SERS studies [125,133,141,151,157,160-163,166]. Many of them revealed great applicability with exceptional LODs. Hence such Au NPs probes for SERS-based melamine identification in milk stuffs is highly appreciated.

In this track, melamine recognition was demonstrated by Wang and co-workers through SERS spectra and in filter paper strip [141]. Tri-sodium citrate and dodecasodium of phytic acid (IP6) dual-functionalized Au NPs ( $\mathrm{IP}_{6}$-TC@Au NPs) were applied in the screening process. The above tactic permits the on-site broadcast of melamine in food products. In a similar fashion, Dong et al. developed an aptamer-modified SERS nanosensor and oligonucleotide chip to quantify the melamine via multi-hydrogen-bond formation between thymine and melamine [151]. This method showed a 
LOD at picogram level, and hence such design is highly desirable. The BSA conjugated Au NPs were utilized by Sun and collaborators [131]. Therein, they evaluated the effectiveness of their method in 50 raw milk samples and the results agreed well with chromatographic and mass data. Hence, such strip method can be authenticated as a rapid screening procedure for real-time monitoring of melamine.

BSA-Au NPs-based lateral flow immunoassay was proposed by Zhong and co-workers For rapid discrimination of melamine [153]. This method was also legalised as an effective procedure for melamine detection, but still much focus is required to improve its applicability and detection limits. Subsequently, the catalytic property of antibody conjugated Au NPs was exploited towards melamine determination by Knopp's group [150]. Surface-assisted laser desorption/ionization mass spectrometry (SALDI-MS) was engaged in the quantification of melamine in infant formula and grain powder by Hsieh and co-workers [164]. The melamine (MEL), ammeline (AMN), and ammelide (AMD) were determined by SALDI-MS using Au NPs. This SALDI-MS quantified MEL, AMN, and AMD via mass peaks at $\mathrm{m} / \mathrm{z}$ 127.07, 128.05, and 129.04 were correlated to $[\mathrm{MEL}+\mathrm{H}]^{+},[\mathrm{AMN}+\mathrm{H}]^{+}$, and $[\mathrm{AMD}+\mathrm{H}]^{+}$ ions. Moreover, LODs of MEL, AMN, and AMD were estimated as 5, 10, and $300 \mathrm{nM}$, respectively. Hence, the above tactics of combining SALDI-MS with Au NPs can be validated for rapid screening of melamine. Next, a sonoluminescence-based approach was proposed for melamine discrimination by Liu and collaborators [165], in which the engaged Au NPs were aggregated in the presence of melamine. Therefore, it belongs to the category of the aggregation-induced sensors. Moreover, such sonoluminescence-based analyte sensing still requires more research for on-site inspection of melamine.

Similar to the Au NPs, the Ag NPs mediated discovery of melamine in dairy milk and food products are also well established in modern science [167]. These Ag NPs facilitated melamine assays were operated through colorimetric, SERS, resonance scattering, and fluorescence responses [168-189]. However, the main working principles of Ag NPs assisted melamine sensors were mainly by means of colorimetric responses, initialized through H-bonding, self-assemblies, and electrostatic forces supported aggregation of nanoparticles [16-173,176-178,180-182,185-187]. An example of electrostatic forces induced nanoparticles aggregation by melamine is illustrated in Figure 19. Kumar et al. demonstrated the unmodified Ag NPs towards the detection of melamine via colorimetric response from yellow to red [170]. On the other hand, Ag NPs were also employed in SERS-based quantification of melamine $[175,179,184,188,189]$. Table 2 summarizes the detection methods, instruments employed, optimization status, time required for analyses, linear ranges, LODs, recoveries in spiked samples, and RSDs of Ag NPs-based probes exploited in melamine recognition.

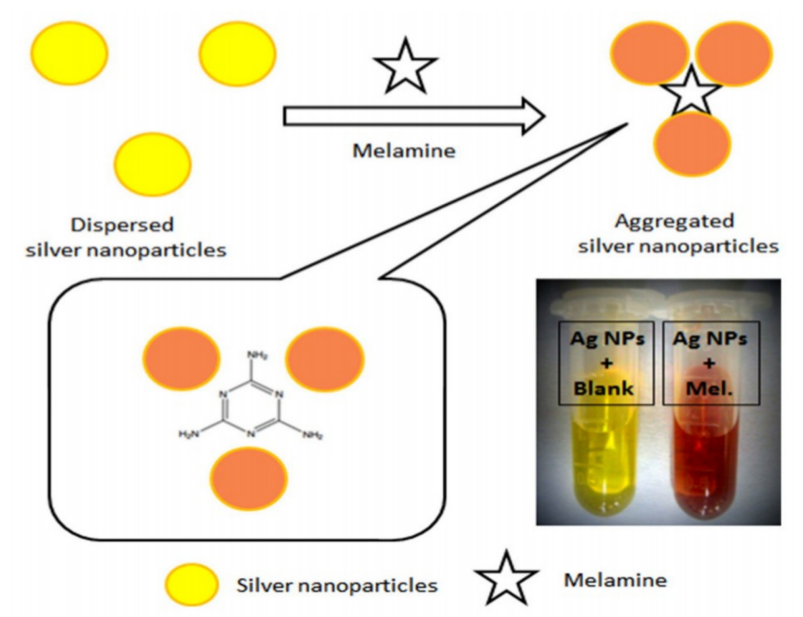

Figure 19. Schematic illustration of melamine detection and visual color change of Ag NPs after addition of melamine. The insert is a photograph of visual color change of Ag NPs upon addition of $1 \mathrm{mg} / \mathrm{L}$ of melamine (reproduced with permission from Reference [170]). 
Table 2. Summary of methods, instruments, optimization status, time, linear ranges, detection limits (LODs), recoveries and relative standard deviations (RSDs) of Ag NPs-based probes in melamine detection.

\begin{tabular}{|c|c|c|c|c|c|c|c|c|}
\hline $\begin{array}{l}\text { Ag NPs-Based } \\
\text { Probe }\end{array}$ & $\begin{array}{l}\text { Method of } \\
\text { Detection }\end{array}$ & $\begin{array}{l}\text { Instruments } \\
\text { Employed }\end{array}$ & $\begin{array}{c}\text { Optimization Status and } \\
\text { Time Required }\end{array}$ & Linear Range & LOD & $\begin{array}{c}\text { Recoveries of } \\
\text { Spiked Samples }\end{array}$ & RSDs & Ref. \\
\hline Label-free Ag NPs & Colorimetric & $\begin{array}{c}\text { Naked eyes and UV-Vis } \\
\text { spectrometer }\end{array}$ & Moderate and $50 \mathrm{~min}$ & $2-250 \mu \mathrm{M}$ & $2.32 \mu \mathrm{M}$ & $88.83-114.29 \%$ & $2.04-3.10 \%$ & [168] \\
\hline Bare Ag NPs & Colorimetric & $\begin{array}{l}\text { Naked eyes and UV-Vis } \\
\text { spectrometer }\end{array}$ & Moderate and30 min & $40-880 \mathrm{nM}$ & $10 \mathrm{nM}$ & $97.5-105 \%$ & $2.98-4.83 \%$ & [169] \\
\hline $\begin{array}{l}\text { Unmodified Ag } \\
\text { NPs }\end{array}$ & Colorimetric & $\begin{array}{l}\text { Naked eyes and UV-Vis } \\
\text { spectrometer }\end{array}$ & Moderate and $20 \mathrm{~min}$ & $0-15.86 \mu \mathrm{M}$ & $0.32 \mathrm{pM}$ & $92.5-99.4 \%$ & $5.26-8.18 \%$ & {$[170]$} \\
\hline Bare Ag NPs & Colorimetric & $\begin{array}{l}\text { Naked eyes and UV-Vis } \\
\text { spectrometer }\end{array}$ & Moderate and $30 \mathrm{~min}$ & $0.26 \mathrm{pM}-11.89 \mu \mathrm{M}$ & $71.4 \mathrm{nM}$ & $61.9-96.3 \%$ & NA & [171] \\
\hline $\begin{array}{l}p \text {-nitroaniline-modified } \\
\text { Ag NPs }\end{array}$ & Colorimetric & $\begin{array}{l}\text { Naked eyes and UV-Vis } \\
\text { spectrometer }\end{array}$ & Moderate and $10 \mathrm{~min}$ & $0.79 \mu \mathrm{M}-79.3 \mathrm{mM}$ & $0.79 \mu \mathrm{M}$ & NA & NA & [172] \\
\hline $\begin{array}{l}\text { Dopamine-stabilized } \\
\text { Ag NPs }\end{array}$ & Colorimetric & $\begin{array}{l}\text { Naked eyes and UV-Vis } \\
\text { spectrometer }\end{array}$ & Moderate and $60 \mathrm{~min}$ & $0.08-10.0 \mu \mathrm{M}$ & $79.3 \mathrm{nM}$ & $92-105 \%$ & NA & [173] \\
\hline $\begin{array}{c}\text { ssDNA-stabilizedAg } \\
\text { NPs }\end{array}$ & $\begin{array}{c}\text { Resonance } \\
\text { scattering }\end{array}$ & $\begin{array}{c}\text { PL and CD } \\
\text { spectrometers etc ... }\end{array}$ & Complicated and $90 \mathrm{~min}$ & $0.05-3 \mu \mathrm{M}$ & $23.8 \mathrm{nM}$ & $98.7-100.9 \%$ & $0.8-3.6 \%$ & [174] \\
\hline $\begin{array}{l}\text { Oleylamine capped } \\
\text { Ag NPs }\end{array}$ & SERS & Raman spectrometer & $\begin{array}{l}\text { Complicated and } \\
>0.5 \mathrm{~min}\end{array}$ & $0.1-100 \mu \mathrm{M}$ & $100 \mathrm{nM}$ & NA & NA & {$[175]$} \\
\hline $\begin{array}{c}\beta \text {-cyclodextrin- } \\
\text { functionalized Ag } \\
\text { NPs }\end{array}$ & Colorimetric & $\begin{array}{l}\text { Naked eyes and UV-Vis } \\
\text { spectrometer }\end{array}$ & Moderate and $30 \mathrm{~min}$ & $1 \mathrm{mM}-50 \mu \mathrm{M}$ & $4.98 \mu \mathrm{M}$ & $80.5-109.02 \%$ & $2.27-3.03 \%$ & {$[176]$} \\
\hline $\begin{array}{c}\text { Chromotropic acid } \\
\text { (CTA)-modified Ag } \\
\text { NPs }\end{array}$ & Colorimetric & $\begin{array}{l}\text { Naked eyes and UV-Vis } \\
\text { spectrometer }\end{array}$ & Moderate and 6 min & $0.10-1.5 \mu \mathrm{M}$ & $36 \mathrm{nM}$ & $91-105 \%$ & NA & [177] \\
\hline $\begin{array}{c}\text { Sulfanilic } \\
\text { acid-modified Ag } \\
\text { NPs }\end{array}$ & Colorimetric & $\begin{array}{l}\text { Naked eyes and UV-Vis } \\
\text { spectrometer }\end{array}$ & Moderate and $5 \mathrm{~min}$ & $0.1-3.1 \mu \mathrm{M}$ & $10.6 \mathrm{nM}$ & $97-109 \%$ & $0.9-1.9 \%$ & [178] \\
\hline $\begin{array}{l}\text { Starch-coated Ag } \\
\text { NPs }\end{array}$ & SERS & $\begin{array}{l}\text { UV-Vis and Raman } \\
\text { spectrometers }\end{array}$ & Complicated and NA & $15.9 \mu \mathrm{M}-0.4 \mathrm{mM}$ & $4.8 \mathrm{nM}$ & $94-104 \%$ & $2.39-4.53 \%$ & [179] \\
\hline $\begin{array}{l}\text { Bio-functionalized } \\
\text { Ag NPs }\end{array}$ & Colorimetric & $\begin{array}{c}\text { Naked eyes and UV-Vis } \\
\text { spectrometer }\end{array}$ & Complicated and $20 \mathrm{~min}$ & $0.015-1 \mathrm{mM}$ & $2 \mu \mathrm{M}$ & $96-122 \%$ & $0.44-2.22 \%$ & [180] \\
\hline $\begin{array}{l}\text { Sodium } \\
\text { D-gluconate-stabilized } \\
\text { Ag NPs }\end{array}$ & Colorimetric & $\begin{array}{l}\text { Naked eyes and UV-Vis } \\
\text { spectrometer }\end{array}$ & Moderate and NA & $0.5-500 \mu \mathrm{M}$ & $476 \mathrm{nM}$ & $90-98 \%$ & NA & [181] \\
\hline $\begin{array}{l}\text { Polyelectrolyte- } \\
\text { stabilized Ag NPs }\end{array}$ & $\begin{array}{c}\begin{array}{c}\text { Colorimetric } \\
\text { and }\end{array} \\
\text { Fluorescence }\end{array}$ & $\begin{array}{l}\text { Naked eyes, UV-Vis } \\
\text { and PL spectrometers }\end{array}$ & Complicated and $20 \mathrm{~min}$ & $\begin{array}{c}1 \mathrm{nM}-1.5 \mu \mathrm{M} \text { and } \\
1.5 \mathrm{nM}-150 \mu \mathrm{M}\end{array}$ & 0.1 and $0.45 \mathrm{nM}$ & $99-114 \%$ & $1.66-4.37 \%$ & [182] \\
\hline
\end{tabular}


Table 2. Cont.

\begin{tabular}{|c|c|c|c|c|c|c|c|c|}
\hline $\begin{array}{l}\text { Ag NPs-Based } \\
\text { Probe }\end{array}$ & $\begin{array}{l}\text { Method of } \\
\text { Detection }\end{array}$ & $\begin{array}{l}\text { Instruments } \\
\text { Employed }\end{array}$ & $\begin{array}{c}\text { Optimization Status and } \\
\text { Time Required }\end{array}$ & Linear Range & LOD & $\begin{array}{l}\text { Recoveries of } \\
\text { Spiked Samples }\end{array}$ & RSDs & Ref. \\
\hline $\begin{array}{c}\text { Citrate and } \\
\text { Borohydride } \\
\text { stabilized Ag NPs }\end{array}$ & Colorimetric & $\begin{array}{l}\text { Naked eyes and UV-Vis } \\
\text { spectrometer }\end{array}$ & Moderate and NA & NA & NA & NA & NA & [183] \\
\hline $\begin{array}{l}\text { Ag NPs monolayer } \\
\text { film }\end{array}$ & SERS & Raman spectrometer & Complicated and $>15 \mathrm{~min}$ & $0.79 \mathrm{pM}-39.6 \mu \mathrm{M}$ & $0.32 \mathrm{pM}$ & $90-95.4 \%$ & $3.7-6.9 \%$ & [184] \\
\hline $\begin{array}{c}\text { Tannic } \\
\text { acid-stabilized } \\
\text { Ag NPs }\end{array}$ & Colorimetric & $\begin{array}{l}\text { Naked eyes and UV-Vis } \\
\text { spectrometer }\end{array}$ & Moderate and $20 \mathrm{~min}$ & $0.05-1.4 \mu \mathrm{M}$ & $0.01 \mu \mathrm{M}$ & $98.5-106.5 \%$ & $1.04-3.19 \%$ & [185] \\
\hline $\begin{array}{c}\text { Bio-functionalized } \\
\text { Ag NPs }\end{array}$ & Colorimetric & $\begin{array}{l}\text { UV-Vis and Raman } \\
\text { spectrometers }\end{array}$ & Moderate and $>1 \mathrm{~min}$ & $0.79-40 \mu \mathrm{M}$ & $\begin{array}{l}0.79 \text { and } \\
3.96 \mu \mathrm{M}\end{array}$ & $96 \%$ & NA & [186] \\
\hline $\begin{array}{c}\text { Green synthesized } \\
\text { Ag NPs }\end{array}$ & Colorimetric & $\begin{array}{l}\text { Naked eyes and UV-Vis } \\
\text { spectrometer }\end{array}$ & Moderate and NA & $0.79-79.3 \mu \mathrm{M}$ & $793 \mathrm{nM}$ & NA & NA & [187] \\
\hline $\begin{array}{c}\text { Acid-directed } \\
\text { synthesis of Ag NPs }\end{array}$ & SERS & Raman spectrometer & Complicated and NA & $0-0.396 \mathrm{mM}$ & $39.64 \mu \mathrm{M}$ & NA & NA & [188] \\
\hline $\begin{array}{l}\text { Chitosan-modified } \\
\text { Ag NPs }\end{array}$ & SERS & $\begin{array}{l}\text { Chromatography and } \\
\text { Raman spectrometer }\end{array}$ & Complicated and $>1 \mathrm{~min}$ & $0-79.3 \mu \mathrm{M}$ & $7.93 \mu \mathrm{M}$ & NA & NA & [189] \\
\hline
\end{tabular}

$\mathrm{NA}=$ Not available $; \mathrm{mM}=$ millimole $; \mu \mathrm{M}=$ micromole $; \mathrm{nM}=$ nanomole $; \mathrm{min}=$ minutes 
Next, as displayed in Figure 20, the chromotropic acid (CTA)-capped AgNPs towards H-bonding facilitated the sensing of melamine [177]. The $-\mathrm{NH}_{2}$ group of melamine $\mathrm{H}$-bonded with $-\mathrm{SO}_{3}$ group of chromotropic acid. Hence, such functionalized Ag NPs can be applied towards the determination of melamine and other analytes. Zhu et al. presented the polyelectrolyte functionalized Ag NPs for selective assay of melamine through colorimetric and fluorescence responses [182], in which the aggregation of particles led to sensor responses in the presence of melamine. The values of effective recovery, linear ranges, and LODs (see Table 2) demonstrated the suitability for real-time screening of melamine in food stuffs. Therefore, designing such probes with dual responses are much desired. Identification of melamine in dairy products was meritoriously carried out by Ag NPs via SERS and resonance scattering studies. As shown in Table 2, the Ag NPs-based SERS sensors have competitive linear ranges, recoveries, and LODs. Therefore, such designs are much anticipated for real-time examination of melamine. A resonance scattering-based detection procedure was described by Liang and co-workers [174]. The linear recovery ranges and LOD reported by this technique were found to be decent, and hence can be engaged in future analytical practicalities.

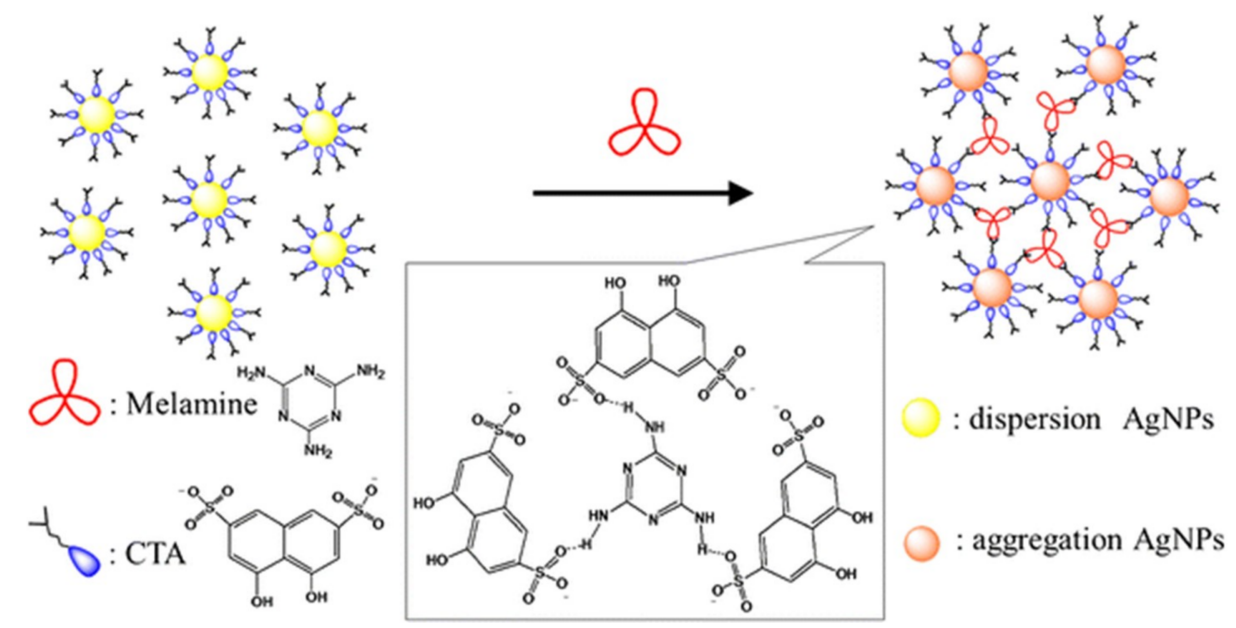

Figure 20. Schematic illustration of possible mechanism for sensing melamine based on CTA-AgNPs (reproduced with permission from Reference [177]).

Other than the Au NPs and the Ag NPs, Au-Ag bi-metallic nanoparticles (CSP NPs) were also employed in the sensing of melamine. For example, Li et al. described the bifunctional chitosan-modified popcorn-like Au-Ag nanoparticles for the colorimetric and SERS-based determination of melamine in milk powder samples [190]. The colorimetric response of CSP NPs were attributed to the peroxidase-like catalytic activity (in presence of melamine) in the oxidation of 3,3',5,5'-tetramethylbenzidine (TMB) by $\mathrm{H}_{2} \mathrm{O}_{2}$. Wherein, the linear range of detection was from $10 \mathrm{nM}$ to $50 \mu \mathrm{M}$ with a LOD of $8.51 \mathrm{nM}$. Moreover, the recoveries were between $90.86 \sim 106.29 \%$ with 1.66 4.29\% RSDs. Therefore, such bi-metallic NPs can be utilized towards real-time examination of melamine in dairy products. On this path, sodium polystyrene sulfonate capped $\mathrm{Cu}_{2-x} \mathrm{Se}$ nanoparticles $\left(\mathrm{Cu}_{2-\mathrm{x}} \mathrm{Se} @ \mathrm{PSS}\right)$ were reported for melamine recognition by means of aggregation-induced superior peroxidase-like activity [191]. Huang's research unit explained the peroxidase-like activity of $\mathrm{Cu}_{2-\mathrm{x}} \mathrm{Se} @ \mathrm{PSS}$ in the presence of melamine, which helped the oxidation of 3,3',5,5'-tetramethylbenzidine (TMB-colorless) by $\mathrm{H}_{2} \mathrm{O}_{2}$ to blue-colored oxidized TMB. The NPs displayed the linearity for melamine with range from $4.7 \mathrm{nM}$ to $29.7 \mathrm{mM}$ and a LOD of $1.2 \mathrm{nM}$. However, the applicability of this work still requires further proof in real samples.

Se NPs were proposed by Wang and collaborators through test strips analysis towards the sensing of melamine [192]. This method shows a LOD of $1 \mathrm{Ag} / \mathrm{Kg}$ in liquid milk, which confirms its effectiveness in melamine discrimination. Shen et al. demonstrated the assay of melamine by dopamine conjugated methoxypoly (ethylene glycol) carboxyl acid (mPEG-COOH) and 
(2,4,6-trioxo-1,3,5-triazin-1-yl) acetic acid-functionalized $\mathrm{Fe} / \mathrm{Fe}_{3} \mathrm{O}_{4}$ nanoparticles (TTAA-Fe $/ \mathrm{Fe}_{3} \mathrm{O}_{4}$ NPs) [193]. The melamine recognition was attributed to the H-bonding interaction between functional moieties with melamine. The probe displayed the linearity from 0 to $16 \mu \mathrm{M}$ with a LOD of $2 \mu \mathrm{M}$. This work does establish its applicability on real samples, and hence can contribute to melamine assay process. $\mathrm{Li}$ and co-workers described the determination of melamine by means of C-dots stabilized Ag NPs [194], in which the C-dots acted both as a reducer and a stabilizer. The above work demonstrated the melamine detection via visible and fluorescence responses between $0 \sim 2 \mu \mathrm{M}$ and 2 20 $\mu \mathrm{M}$, respectively, with a LOD of $30 \mathrm{nM}$. Moreover, recoveries of melamine in raw milk samples were between $95.71 \sim 113.58 \%$ with $2.9 \sim 4.3 \%$ RSDs. Other than the detection of melamine by functionalized NPs, melamine-stabilized NPs were also used in the assay of food contaminants [195]. Therefore, such a scheme can be further directed towards the identification of melamine in real samples as well [10].

\section{Nanorods and Nanotubes in Melamine Assay}

Due to the requirement of diverse techniques for melamine assay in food products, researchers also explored the possibility of using the nanorods and nanotubes for melamine discrimination, as discussed in this section. In 2010, Wei's group reported the melamine sensing through bis(8-quinolinolato)zinc(II) complex nanorod arrays [196]. In which, nanorods with diameters of 250 to $320 \mathrm{~nm}$ and lengths of $\sim 25 \mu \mathrm{m}$ were fabricated via liquid-liquid interfacial precipitation in the pores of porous anodic aluminum oxide membrane. These arrays displayed the linearity to melamine from 39.6 to $238 \mathrm{nM}$, and hence can be used as a suitable method for melamine assay. However, much work is still needed for this type of array. Following the above work, Chen and co-workers detected the melamine using the SERS ability of $\mathrm{ZnO} / \mathrm{Au}$ nanoneedle arrays [197]. This work demonstrated the melamine determination from $10 \mathrm{nM}$ to $100 \mu \mathrm{M}$ with a LOD of $10 \mathrm{nM}$. Moreover, the authors also confirmed the melamine quantifying ability of $\mathrm{ZnO} / \mathrm{Au}$ nanoneedles in egg-white solution. Due to the complications in optimization conditions, this method requires further modification for on-site melamine screening. In a similar fashion, Ag-nanoparticle-modified single Ag nanowires (Ag NP/Ag NWs) were exploited in the SERS-based quantification of melamine [198]. The Ag NWs were synthesized by solvothermal method and then decorated with the Ag NPs. The Ag NP/Ag NW showed great SERS response to melamine concentrations from $10 \mathrm{nM}$ to $22 \mu \mathrm{M}$ with a LOD of $10 \mathrm{n}$ M. Moreover, this rapid detection approach was validated by quantifying melamine in milk solution with the detected melamine concentration as low as $50 \mathrm{n} \mathrm{M}$. Even though the technique attested is one of the best tactics, complications involved in the optimization procedures still need to be rectified.

SERS effect engaged with Ag NPs coated ZnO (Ag@ZnO) nanorod arrays for the discovery of melamine was reported by $\mathrm{Xu}$ and collaborators [199]. However, much focus is still required to establish the melamine quantification by Ag@ZnO nanorod arrays. On the other hand, carbon nanotubes-based electrochemical assay of melamine was described by Li and Zhao research groups $[200,201]$. Li et al. employed the nanocomposite of hydroxyapatite/carbon nanotubes for the determination of melamine using Ascorbic acid (AA) as a recognition element [200]. Under the optimum condition, the decrease in anodic peak current of AA was linearly proportional to the melamine concentrations from 10 to $350 \mathrm{nM}$ with a LOD of $1.5 \mathrm{nM}$. This electrochemical method demonstrated good recoveries in infant formula and milk samples, which were between $98.5 \sim 102.5 \%$ with $1.32 \sim 2.58 \%$ RSDs. On a similar track, Zhao et al. presented the assay of melamine by employing the glassy carbon electrode coated with a multi-wall carbon nanotube/chitosan composite [201]. The linear melamine concentrations were from 9.9 to $190 \mathrm{nM}$ with a LOD of $3 \mathrm{nM}$. Moreover, this work was also demonstrated in milk samples with a recovery rate of $104.8 \%$. These electrochemical studies also require the reduction of the optimization complications in order to be of use in real-time screening of melamine. Notably, in the main stream these reports displayed complications in their optimization along with the great recoveries and linearity in melamine detection, as summarized in Table 3. 
Table 3. Summary of methods, instruments, optimization status, time, linear ranges, detection limits (LODs), recoveries and relative standard deviations (RSDs) of Nanorods and Nanotubes-based probes in melamine detection.

\begin{tabular}{|c|c|c|c|c|c|c|c|c|}
\hline $\begin{array}{l}\text { Nanotube/Nanorod/ } \\
\text { Nanowire Arrays }\end{array}$ & $\begin{array}{l}\text { Method of } \\
\text { Detection }\end{array}$ & $\begin{array}{l}\text { Instruments } \\
\text { Employed }\end{array}$ & $\begin{array}{l}\text { Optimization Status and } \\
\text { Time Required }\end{array}$ & Linear Range & LOD & $\begin{array}{c}\text { Recoveries of } \\
\text { Spiked Samples }\end{array}$ & RSDs & Ref. \\
\hline $\begin{array}{l}\text { Bis(8-quinolinolato) } \\
\text { zinc (II) complex } \\
\text { nanorod arrays }\end{array}$ & Fluorescence & PL spectrometer & Moderate and NA & $39.6 \mathrm{nM}-238 \mathrm{n} \mathrm{M}$ & NA & NA & NA & [196] \\
\hline $\begin{array}{l}\mathrm{ZnO} / \mathrm{Au} \text { composite } \\
\text { nano arrays }\end{array}$ & SERS & Raman spectrometer & $\begin{array}{l}\text { Complicated and } \\
\quad>0.5 \mathrm{~min}\end{array}$ & $100 \mu \mathrm{M}-10 \mathrm{nM}$ & $10 \mathrm{nM}$ & NA & $\mathrm{NA}$ & [197] \\
\hline $\begin{array}{l}\text { Ag-nanoparticle-modifie } \\
\text { single Ag nanowire }\end{array}$ & SERS & Raman spectrometer & Complicated and $60 \mathrm{~min}$ & $10 \mathrm{nM}-22 \mu \mathrm{M}$ & $10 \mathrm{nM}$ & NA & NA & [198] \\
\hline $\begin{array}{l}\text { hydroxyapatite/carbon } \\
\text { nanotubes } \\
\text { glassy carbon }\end{array}$ & Electrochemical & Cyclic voltammeter & Complicated and $9 \mathrm{~min}$ & $10-350 \mathrm{nM}$ & $1.5 \mathrm{nM}$ & $98.5-102.5 \%$ & $1.32-2.58 \%$ & [200] \\
\hline $\begin{array}{l}\text { electrode coated } \\
\text { with a multi-wall } \\
\text { carbon } \\
\text { nanotube/chitosan }\end{array}$ & Electrochemical & Cyclic voltammeter & Complicated and $20 \mathrm{~min}$ & $9.9-190 \mathrm{nM}$ & $3 \mathrm{nM}$ & $104.8 \%$ & NA & [201] \\
\hline $\begin{array}{l}\text { Vertically aligned } \\
\text { monolayer of } \\
\text { Aunanorods }\end{array}$ & SERS & Raman spectrometer & Complicated and $90 \mathrm{~min}$ & NA & $\sim 0.9 \mathrm{fM}$ & NA & NA & [202] \\
\hline $\begin{array}{c}\text { Single gold } \\
\text { nanoparticles } \\
\text { decorated } \\
\text { silver/carbon } \\
\text { nanowires }\end{array}$ & SERS & Raman spectrometer & Complicated and $60 \mathrm{~min}$ & $0.1-220 \mu \mathrm{M}$ & $0.1 \mu \mathrm{M}$ & NA & NA & [203] \\
\hline $\begin{array}{l}\text { Au nanorods } \\
\text { coupled with Ag } \\
\text { nanoparticles }\end{array}$ & SERS & $\begin{array}{l}\text { Focus ion beam and } \\
\text { Raman spectrometer }\end{array}$ & $\begin{array}{l}\text { Complicated and } \\
\quad>0.5 \mathrm{~min}\end{array}$ & $1 \mathrm{mM}-1 \mathrm{pM}$ & $1 \mathrm{pM}$ & NA & NA & [204] \\
\hline $\begin{array}{l}\text { disordered silver } \\
\text { nanowires } \\
\text { membrane }\end{array}$ & SERS & Raman spectrometer & Moderate and $>0.5 \mathrm{~min}$ & $7.93 \mu \mathrm{M}-0.79 \mathrm{mM}$ & NA & NA & NA & [205] \\
\hline $\begin{array}{c}\text { Ag nanoparticles } \\
\text { surrounding } \\
\text { triangular } \\
\text { nanoarrays }\end{array}$ & SERS & Raman spectrometer & Complicated and NA & $0.5-500 \mu \mathrm{M}$ & $10 \mu \mathrm{M}$ & NA & NA & [206] \\
\hline $\begin{array}{c}\mathrm{ZnGa}_{2} \mathrm{O}_{4} \text { Nanorod } \\
\text { Arrays Decorated } \\
\text { with Ag } \\
\text { Nanoparticles }\end{array}$ & SERS & Raman spectrometer & Complicated and $>1 \mathrm{~min}$ & $0.1-100 \mu \mathrm{M}$ & $0.1 \mu \mathrm{M}$ & NA & NA & [207] \\
\hline
\end{tabular}


Table 3. Cont.

\begin{tabular}{|c|c|c|c|c|c|c|c|c|}
\hline $\begin{array}{l}\text { Nanotube/Nanorod/ } \\
\text { Nanowire Arrays }\end{array}$ & $\begin{array}{l}\text { Method of } \\
\text { Detection }\end{array}$ & $\begin{array}{l}\text { Instruments } \\
\text { Employed }\end{array}$ & $\begin{array}{l}\text { Optimization Status and } \\
\text { Time Required }\end{array}$ & Linear Range & LOD & $\begin{array}{c}\text { Recoveries of } \\
\text { Spiked Samples }\end{array}$ & RSDs & Ref. \\
\hline $\begin{array}{c}\text { Au nanorod arrays } \\
\text { fabrication using a } \\
\text { focused gallium } \\
\text { (Ga) ion beam } \\
\text { [Ru }\end{array}$ & SERS & $\begin{array}{l}\text { Focus ion beam and } \\
\text { Raman spectrometer }\end{array}$ & Complicate \& $>1 \mathrm{~min}$ & $100 \mu \mathrm{M}-1 \mathrm{pM}$ & $1 \mathrm{pM}$ & NA & NA & {$[208]$} \\
\hline $\begin{array}{c}\left.(\mathrm{bpy})_{3}\right]^{2+} \text {-doped } \mathrm{Si} \\
\mathrm{NPs} / \text { multi-walled } \\
\text { carbon } \\
\text { nanotubes/Nafion } \\
\text { composite electrode }\end{array}$ & $\begin{array}{l}\text { Electro- } \\
\text { chemiluminescence }\end{array}$ & $\begin{array}{c}\text { Multifunction } \\
\text { chemiluminescence } \\
\text { detector }\end{array}$ & Complicate \&NA & $0.1 \mu \mathrm{M}-0.5 \mathrm{pM}$ & $0.1 \mathrm{pM}$ & $99.7-102 \%$ & $1.1-3.1 \%$ & {$[209]$} \\
\hline $\begin{array}{l}\text { Ag nanorod } \\
(\text { Ag NR) array }\end{array}$ & SERS & Raman spectrometer & Moderate $\&>0.5 \mathrm{~min}$ & $15.86 \mu \mathrm{M}-1.59 \mathrm{mM}$ & $7.1 \mu \mathrm{M}$ & $89.7-93.3 \%$ & $1.08-2.02 \%$ & {$[210]$} \\
\hline $\begin{array}{l}\text { Flexible silicon } \\
\text { nanowires }\end{array}$ & SERS & Raman spectrometer & Moderate $\&>0.5 \mathrm{~min}$ & $79 \mathrm{pM}-0.79 \mathrm{mM}$ & $2.5 \mathrm{nM}$ & NA & NA & {$[211]$} \\
\hline $\begin{array}{l}\text { CarbonNitride } \\
\text { Nanotubes }\end{array}$ & $\begin{array}{c}\text { Molecular } \\
\text { Imprinted } \\
\text { Voltammetry }\end{array}$ & Cyclic voltammeter & Moderate \& 30 min & $0.1-5 \mathrm{nM}$ & $10 \mathrm{pM}$ & $98.68-102.94 \%$ & NA & {$[212]$} \\
\hline $\begin{array}{c}\text { Molybdenum } \\
\text { Oxide-nanowires @ } \\
\mathrm{Au}\end{array}$ & SERS & Raman spectrometer & Complicate \& $>24 \mathrm{~h}$ & $0.79 \mathrm{nM}-0.79 \mathrm{mM}$ & $0.792 \mathrm{nM}$ & NA & NA & {$[213]$} \\
\hline $\begin{array}{c}\text { Zinc oxide } \\
\text { Nanowires } \\
\text { decorated with Ag } \\
\text { NPs }\end{array}$ & SERS & Raman spectrometer & Moderate \& $60 \mathrm{~min}$ & $12 \mu \mathrm{M}-76 \mu \mathrm{M}$ & NA & NA & NA & {$[214]$} \\
\hline $\begin{array}{l}\text { Ag nanorod from } \\
\text { polymeric silver } \\
\text { cyanide }\end{array}$ & SERS & Raman spectrometer & Moderate \& NA & $1 \mathrm{mM}-1 \mathrm{pM}$ & NA & NA & NA & {$[215]$} \\
\hline $\begin{array}{l}\text { Ag nanoparticles } \\
\text { decorated } \mathrm{Cu}(\mathrm{OH})_{2} \\
\text { nanoneedle }\end{array}$ & SERS & Raman spectrometer & Complicate \& NA & NA & $0.792 \mathrm{nM}$ & NA & NA & {$[216]$} \\
\hline $\begin{array}{l}\text { Ag NPs decorated } \\
\text { Zinc Oxide/ } \\
\text { Siliconhetrostructured } \\
\text { nanomace Arrays }\end{array}$ & SERS & Raman spectrometer & Complicate $\&>0.5 \mathrm{~min}$ & $10 \mu \mathrm{M}-0.1 \mathrm{nM}$ & $10 \mathrm{fM}$ & NA & NA & {$[217]$} \\
\hline
\end{tabular}

$\mathrm{NA}=$ Not available $\mathrm{mM}=$ millimole $\mu \mathrm{M}=$ micromole; $\mathrm{nM}=$ nanomole; $\mathrm{pM}=$ picomole; $\mathrm{fM}$ = femtomole; min = minutes; Hrs = Hours. 
The majority of nanowires/nanorods/nanotubes-based composite arrays engaged in melamine detection were attributed to the SERS effect of the substrate fabricated and subjected to the analysis [197-199,202-208,210,211,213-217]. In contrast, some tactics, such as fluorescence [196], electrochemical [200,201], electrochemiluminescence (ECL) [209], and voltammetry [212] were also employed in the discriminative assay of melamine. From the table, one can conclude that nanorod/nanowires/nanotubes arrays can be engaged as SERS substrates in making successful assays for the melamine detection in milk samples. However, much focus is still required to reduce the optimization complications and to enhance the linear range of detection and recoveries.

\section{Other Nanostructures in Melamine Discrimination}

Few research units have demonstrated the melamine determination through diverse nanostructures, as illustrated next. Rajkumar and co-workers presented the diverse nanostructured Ag NPs deposited on silicon substrates via one-step galvanic displacement method, which was further engaged in the SERS-based detection of melamine [218]. As shown in Figure 21, the SERS peak at $685 \mathrm{~cm}^{-1}$ distinguishes the presence of melamine between $1 \mathrm{mM}$ to $0.1 \mathrm{nM}$. This work showed a LOD of melamine of $\sim 10 \mathrm{nM}$, and hence established its affordability in real-time monitoring of melamine. Using this SERS-based sensing approach, Zhang et al. presented the sandwich-type nanostructured substrate consisted of a probe molecule sandwiched between silver nanoparticles (SNPs) and silver nanoarrays for the selective assay of melamine [219]. The above sandwich nanostructure was fabricated on porous anodic aluminum oxide (AAO) by means of electrodepositing technique. The probe showed linearity to melamine between $1 \mathrm{mM}$ to $1 \mathrm{nM}$ and displayed a sensitivity up to $1 \mathrm{nM}$. However, the authors did not provide any clear information of the probe molecules. Hence, extensive melamine detection using the probe in dairy products is still questionable.

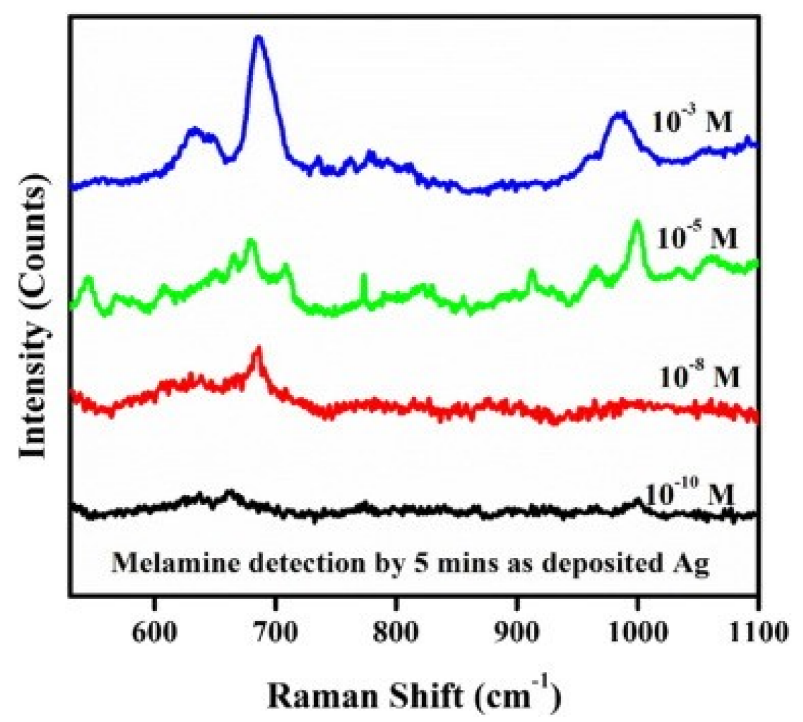

Figure 21. SERS Spectra of Melamine with different concentrations for 5 min Ag deposited samples (reproduced with permission from Reference [218]).

For the determination of melamine using electrochemical sensing, Cadmium doped antimony oxide nanostructures (CAO-NSs) were employed to modify the glassy carbon electrode [220]. The CAO-NSs/GCE demonstrated the linearity in melamine assay from $0.05 \mathrm{nM}-0.5 \mathrm{mM}$ with a LOD of $14 \pm 0.05$ pM. Recoveries by this method in milk samples were established between $97.3 \sim 103.5 \%$ with 1.9 3.5\% RSDs. This electrochemical method appears to be one of the best techniques, and hence can be employed for the discrimination of melamine in dairy stuffs. Ibupoto's research utilized the succinic acid-functionalized copper oxide nanostructures to modify the GCE and then applied in the electrochemical discovery of melamine [221]. The GCE/CuO-NSs/nafion detected the melamine 
linearly between $100 \mathrm{pM}$ to $5.6 \mathrm{nM}$ with a LOD of $10 \mathrm{pM}$. Recoveries by this nanostructure were 98 99\% with 0.31 0.83\% RSDs. Due to the excellent selectivity to melamine, the modified electrode can be validated as a great innovation in the melamine sensing.

Guo et al. presented a SERS-based melamine quantification in milk samples by employing the hollow gold nanospheres (HGNs) on glass wafers via electrostatic interaction as illustrated in Figure 22 [222]. Here, the HGNs displayed a strong SERS enhancement to melamine due to its ability to confine the electromagnetic fields around the pinholes in hollow shells. The hollow gold chip discovered the melamine linearly between 0 to $793 \mu \mathrm{M}$ with a LOD of $7.93 \mu \mathrm{M}$. This method was validated in milk samples, but it can only be considered as an addition to those SERS-mediated detection tactics. Similar to the SERS methods, Jean and collaborators proposed the optical sensing of melamine by means of $\mathrm{Ag}$ decorated silica nanoparticles $\left(\mathrm{SiO}_{2} @ \mathrm{Ag}\right.$ nanospheres) [223]. The optical sensor can sense the melamine at $\mathrm{nM}$ level with great sensitivity between $793 \mathrm{nM}$ to $7.93 \mathrm{mM}$. Silver nanoparticles coated amino modified polystyrene microspheres (PS- $\mathrm{NH}_{2} / \mathrm{Ag} \mathrm{NPs}$ ) were demonstrated in the assay of melamine by Zhao and collaborators [224]. The melamine detection displayed linear regression from $1 \mathrm{mM}$ to $10 \mathrm{nM}$ at $698 \mathrm{~cm}^{-1}$ and have a LOD of $19 \mathrm{nM}$. Moreover, this work was demonstrated in milk powder samples without any sample pretreatment steps. Hence, it can be engaged in real-time inspection of melamine contamination.

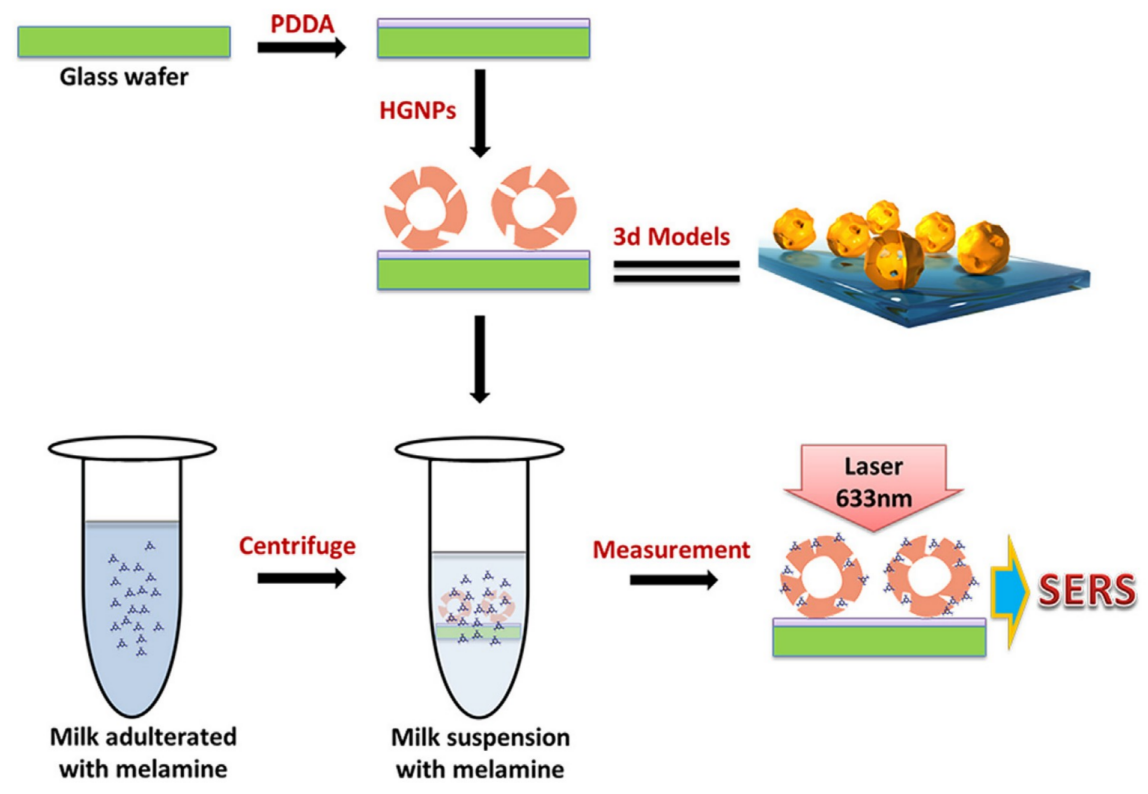

Figure 22. Procedures of hollow gold (HG) chip fabrication and detection procedures of melamine from real milk sample by HG chip (reproduced with permission from Reference [222]).

The SERS-based determination of melamine was further established using $\mathrm{Ag} @ S i O_{2}$ nanocubes by Su and Hwang's research groups [225]. The above nanocube materials displayed the linearity to melamine from 0.5 to $7.93 \mu \mathrm{M}$ at $684 \mathrm{~cm}^{-1}$ with a LOD of $0.48 \mu \mathrm{M}$. Moreover, $\mathrm{Ag} @ S \mathrm{SiO}_{2}$ nanocubes also showed the linear melamine detection in milk samples, which was between 2.46 to $39.6 \mu \mathrm{M}$ with a LOD of $1.35 \mu \mathrm{M}$. Recoveries in spiked milk samples were found as 94.86 to $99.87 \%$ with $11.11 \sim 17.11 \%$ RSDs. This method can be categorized as a suitable SERS method. In a similar fashion, Qin et al. reported the hollow nanocubes made of Ag-Au alloys for SERS-based recognition of melamine [226], in which the sensitivity to melamine was established at $701 \mathrm{~cm}^{-1}$ at a concentration as low as $10 \mathrm{nM}$. Even though this work is elaborated, still much focus is required to verify its potentiality in milk products. Chen et al. demonstrated the applicability of urchin-like $\mathrm{LaVO}_{4} / \mathrm{Au}$ composite microspheres towards the melamine discovery via SERS responses at $682 \mathrm{~cm}^{-1}$ with linearity between $10 \mu \mathrm{M}$ to $1 \mathrm{nM}$ [227]. LOD of melamine recognition by this tactic was estimated to be $1 \mathrm{nM}$, and hence can be categorized as one of the SERS methods. However, the applicability of this probe is still in need of verification. 
A portable multi-channel sensing device comprised of Au nano-urchins was described by Huang and Chen collaborators via localized surface plasmon resonance (LSPR) at $680 \mathrm{~nm}$ [228]. In the presence of melamine the LSPR peak at $680 \mathrm{~nm}$ was enhanced and exhibited linear regression between 0.1 to $1 \mu \mathrm{M}$ with a LOD of $18 \mathrm{nM}$. Potentiality of the above research needs to be validated in real samples for future applications. As shown in Figure 23, Nguyen et al. presented the use of sharp-edged gold nanostar (Au NSs) substrates via SERS response at $714 \mathrm{~cm}^{-1}$ for on-site determination of melamine in infant formula and chocolate [229]. They compared the potentiality of Au NSs with the spherical Au NPs. In the infant formula, the Au NSs and Au NPs showed the linear regressions of 0.79-793 nM and $79.3 \mathrm{nM}-39.6 \mu \mathrm{M}$ with LODs of $79.3 \mathrm{nM}$ and $0.79 \mu \mathrm{M}$, respectively. Similarly, Au NSs and Au NPs showed the linear regressions of $7.93 \mathrm{nM}-19.8 \mu \mathrm{M}$ and 7.93-79.3 $\mu \mathrm{M}$ in chocolate mixture with LODs of $0.79 \mu \mathrm{M}$ and $79.3 \mu \mathrm{M}$, correspondingly. Due to the authenticated real-time application, this nanostructured probe can be used for efficient monitoring of melamine in dairy products.
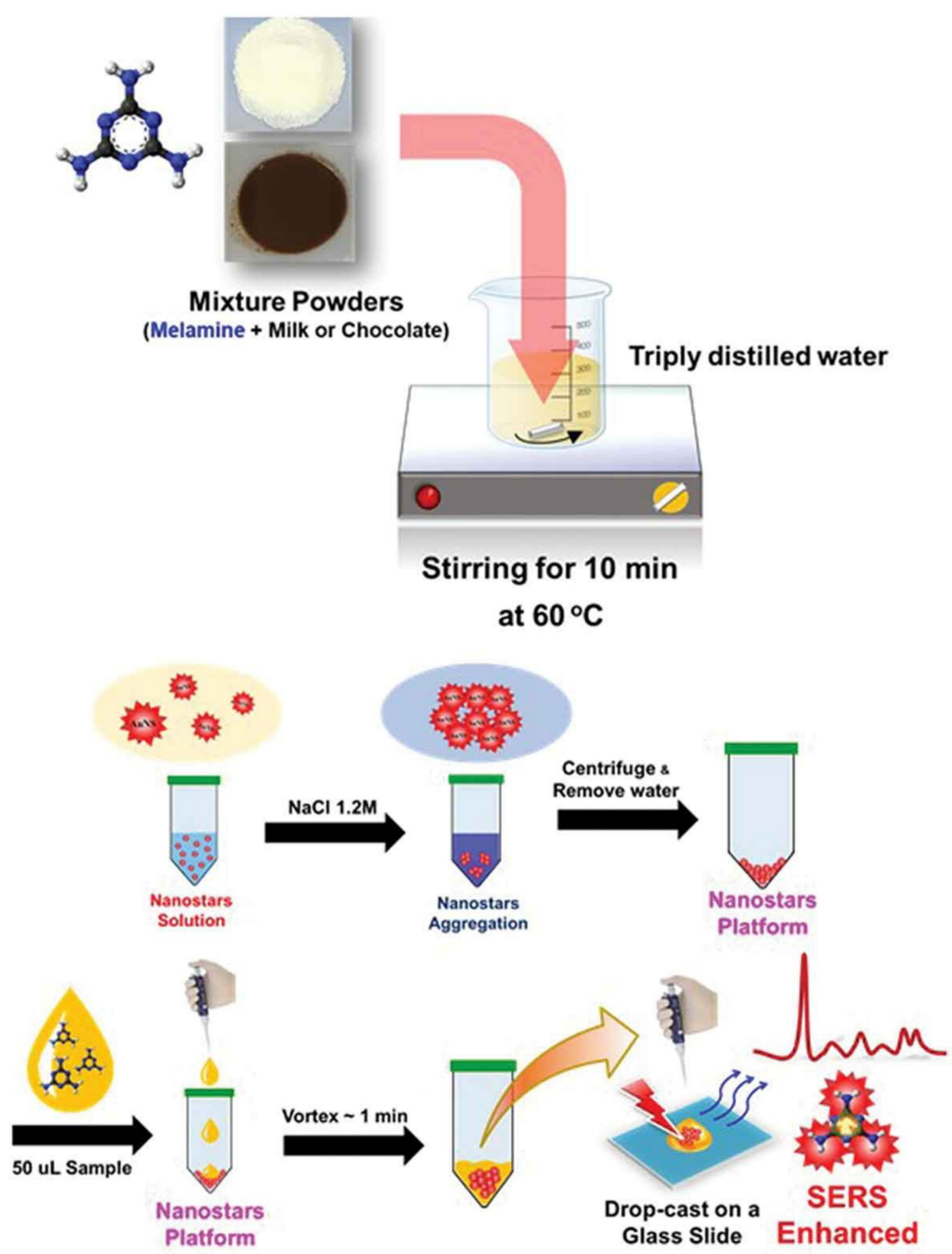

Figure 23. Experimental schemes for detecting melamine in powdered infant formula and chocolate. On-site detection of sub-mg/kg melamine could be achieved using Raman spectroscopy within a few minutes (reproduced with permission from Reference [229]).

As a different nanostructured material, gold coated zinc oxide nanonecklaces ( $\mathrm{ZnO} \mathrm{NN}$ ) arrays were utilized towards melamine sensing by He and co-workers [230]. These $\mathrm{ZnO} \mathrm{NN}$ arrays detected the melamine via SERS signal at $683 \mathrm{~cm}^{-1}$ with a LOD of $10 \mu \mathrm{M}$. Between $10 \mathrm{mM}$ to $1 \mu \mathrm{M}$, the probe 
displayed the linearity, but the sensitivity towards melamine still needed to be improved for real-time application. In this track, gold-sputtered Blu-ray discs (BD-R) were employed to discover melamine by Nieuwoudt et al. via SERS signal at $683 \mathrm{~cm}^{-1}$ [231]. From concentrations of melamine of $0.79 \mathrm{nM}$ to $7.93 \mathrm{mM}$ the SERS signals were observed with a LOD of $555 \mathrm{nM}$. However, although the above method shows the lowest detection range, the reliability is not well demonstrated. Using the SERS-based tactics, Cao and co-workers demonstrated the trace level melamine sensing by self-assembly of silver nanostructures on carbon-coated copper grids [232]. By means of surfactant-free and ultrafast self-assembly over carbon-coated copper TEM grids, well defined silver structures comprised of nano-flowers (NFs), planar nanospheres (NSs), and nano-dendrites (NDs) were fabricated and applied in the SERS-based melamine recognition studies. At $688 \mathrm{~cm}^{-1}$, the SERS signal of melamine displayed linearity between $10 \mathrm{pM}$ to $1 \mu \mathrm{M}$ with a LOD of $10 \mathrm{pM}$. The grids used in this method can be re-used after exposure to air for six months and can still achieve the same performance. Therefore, this method is authenticated as one of best SERS-based techniques for real-time inspection of melamine in food stuffs.

Similar to the self-assembly of nanostructures, melamine and its derivatives can produce nanostructures via H-bonding with suitable candidates or by self-assembly [233-239]. Functional materials can form during these process, which may find their use in melamine detection in near future. For example, the H-bonded hydrogel formed by melamine with a molecule Nap-FFYGK-CA was reported as a good tactic for the assay by Yang and Chen collaborators [234]. The above work was demonstrated in milk and urine samples, and can thus be employed as a valid scheme for melamine discrimination in future.

\section{Advantages and Limitations}

The nanomaterial-based melamine assays have several advantages as well as limitations as stated below.

(1) Many novel designs from nanomaterials have been proved their effectiveness towards melamine quantifications in milk and food stuffs via dissimilar detection methodologies, which allow the modern world to remain healthy and safe.

(2) The majority of nanomaterial-based melamine sensors have the lowest detection limits (femtomolar to nanomolar) with excellent linearities, and hence can determine the melamine at low concentrations in dairy products.

(3) Diverse tactics in melamine detection have been employed by nanomaterials, which allow them to be utilized towards the inspection of dissimilar contaminated samples. For example, fluorescence and colorimetric tactics of NPs and NCs can help to identify the melamine in solution by the naked eye. On the other hand, SERS and electrochemical techniques may recognize melamine through specific signals from solution and powders.

(4) The metal ion-mediated detection probes for melamine can act as dual-mode sensors to metal ions and melamine in environmental water samples and dairy products, respectively.

(5) The cost-effectiveness of the majority of nanomaterial-based assay tactics in melamine detection appears to be low, and hence can be used in real-time monitoring of melamine.

(6) Design of nanoparticles for melamine determination is limited by the electrostatic forces and functional units presented over their surface, which must show the tendency to form H-bond with melamine or to coordinate/complex with melamine. However, to identify such functional units, extended research work is required.

(7) For metal nanocluster-based assay of melamine, the quantum yield should be improved by modifications with suitable groups [240], otherwise the LODs on melamine quantification will not be improved.

(8) Nanocomposite-based discrimination of melamine is restricted by the compositions of the mixtures which require essential property. Moreover, the development of nanocomposite with essential properties are still time consuming. Therefore much effort is needed in their optimization. 
(9) The nanorods/nanowires/nanotubes-based melamine sensing approaches are limited by their melamine-capture ability. It means that not all of the NWs/NRs/NTs can detect the melamine. Moreover, the main stream of these arrays-based assays is complicated in terms of optimizations. Hence much focus is needed to overcome the difficulties and to enhance the reliability.

(10) To identify the mechanisms behind the melamine sensing processes with nanomaterials, sophisticated instruments, such as TEM, Raman spectroscopy, and cyclic voltammetry are essential, which will affect the cost and time in developing melamine sensing techniques. Therefore, much anticipation is expected for these tactics.

\section{Conclusions and Perspectives}

In this review, we have summarized the nanomaterial-based sensors for illegal food contaminant melamine. Note that this review covers the melamine assays using nanomaterials, such as carbon dots, quantum dots, nanocomposites, nanocrystals, nanoclusters, nanoparticles, nanorods, nanowires, and nanotubes. Moreover, diverse mechanisms, including fluorescence resonance energy transfer (FRET), aggregation, inner filter effect, surface-enhanced Raman scattering (SERS), and self-assembly in melamine determination are discussed in detail. Wherein, Au NPs- and Ag NPs-based colorimetric sensing via aggregation or H-bonding appears to be a promising strategy among the majority of the reports. On the other hand, many scientists have developed diverse nanomaterials, which address the melamine contamination through SERS tactics. Apart from the above methods, a few reports have also covered FRET, CRET, Sonoluminescence, and Chemiluminescence, etc.

However, the following nanomaterial-based melamine assays and mechanisms are still missing, which need to be established in the future.

(1) The C-dots-based assay of melamine is not totally innovative, and hence much attention is required.

(2) Reports on Pt and bi-metallic nanoclusters towards melamine sensing are insufficient. More researchers must devote themselves to this research area.

(3) The mechanisms of a few nanocomposite-based melamine recognitions are not entirely clear, and hence should be further investigated in the future.

(4) Studies on band-gap properties of the nanorods/nanowires/nanotubes-based sensors may help to interpret the mechanisms involved, which should be evaluated in the near future.

(5) Researchers should be encouraged to investigate other nanostructures, such as nanocubes, nanostars, nanoflowers, and nanocrystals towards melamine assays.

Even though developing nanomaterial-based melamine assays requires sophisticated optimization procedures and delicate instruments, they provide a breakthrough in food contamination assay and allow the world to sustain a safe and healthy environment. Moreover, researchers are devoted to the development of nanomaterials, which may revolutionize the current health and food industries

Author Contributions: This review written by M.S and K.W.S with equal contributions.

Conflicts of Interest: The authors declare no conflicts of interest.

\section{References}

1. Luo, Q.; Li, S.; Liu, S.; Tan, H. Foodborne illness outbreaks in China, 2000-2014. Int. J. Clin. Exp. Med. 2017, 10, 5821-5831.

2. Egan, M.B.; Raats, M.M.; Grubb, S.M.; Eves, A.; Lumbers, M.L.; Dean, M.S.; Adams, M.R. A review of food safety and food hygiene training studies in the commercial sector. Food Control 2007, 18, 1180-1190. [CrossRef]

3. Ismail, F.H.; Chik, C.T.; Muhammad, R.; Yusoff, N.M. Food safety knowledge and personal hygiene practices amongst mobile food handlers in Shah Alam, Selangor. Procedia Soc. Behav. Sci. 2016, 222, 290-298. [CrossRef] 
4. García-Miguel, E.; Meza-Márquez, O.G.; Osorio-Revilla, G.; Téllez-Medina, D.I.; Jiménez-Martínez, C.; Cornejo-Mazón, M.; Hernández-Martínez, D.M.; Gallardo-Velazquez, T. Detection of cyanuric acid and melamine in infant formula powders by Mid-FTIR spectroscopy and multivariate analysis. J. Food Qual. 2018, 2018, 7926768. [CrossRef]

5. Ingelfinger, J.R. Melamine and the global implications of food contamination. N. Engl. J. Med. 2008, 359, 2745-2748. [CrossRef] [PubMed]

6. Scholl, P.F.; Bergana, M.M.; Yakes, B.J.; Xie, Z.; Zbylut, S.; Downey, G.; Mossoba, M.; Jablonski, J.; Magaletta, R.; Holroyd, S.E.; et al. Effects of the adulteration technique on the Near-Infrared detection of melamine in milk powder. J. Agric. Food Chem. 2017, 65, 5799-5809. [CrossRef] [PubMed]

7. Anirudhan, T.S.; Christa, J.; Deepa, J.R. Extraction of melamine from milk using a magnetic molecularly imprinted polymer. Food Chem. 2017, 227, 85-92. [CrossRef] [PubMed]

8. Simon, T.; Shellaiah, M.; Steffi, P.; Sun, K.W.; Ko, F.-H. Development of extremely stable dual functionalized gold nanoparticles for effective colorimetric detection of clenbuterol and ractopamine in human urine samples. Anal. Chim. Acta 2018, 1023, 96-104. [CrossRef]

9. Shellaiah, M.; Simon, T.; Venkatesan, P.; Sun, K.W.; Ko, F.-H.; Wu, S.-P. Nanodiamonds conjugated to gold nanoparticles for colorimetric detection of clenbuterol and chromium(III) in urine. Microchim. Acta 2017, 185, 74. [CrossRef]

10. Kang, J.; Zhang, Y.; Li, X.; Miao, L.; Wu, A. A rapid colorimetric sensor of clenbuterol based on cysteamine-modified gold nanoparticles. ACS Appl. Mater. Interfaces 2016, 8, 1-5. [CrossRef]

11. Schwab, M.G.; Fassbender, B.; Spiess, H.W.; Thomas, A.; Feng, X.; Müllen, K. Catalyst-free preparation of melamine-based microporous polymer networks through schiff base chemistry. J. Am. Chem. Soc. 2009, 131, 7216-7217. [CrossRef] [PubMed]

12. Kaboorani, A.; Riedl, B. Improving performance of polyvinyl acetate (PVA) as a binder for wood by combination with melamine based adhesives. Int. J. Adhes. Adhes. 2011, 31, 605-611. [CrossRef]

13. Roviello, G.; Ricciotti, L.; Ferone, C.; Colangelo, F.; Tarallo, O. Fire resistant melamine based organic-geopolymer hybrid composites. Cem. Concr. Compos. 2015, 59, 89-99. [CrossRef]

14. Tanaka, R.; Kurogi, T.; Murata, H. Effect of melamine foam cleaning on the surface condition of composite resin artificial teeth. J. Prosthodont. 2013, 22, 626-632. [CrossRef] [PubMed]

15. Rovina, K.; Siddiquee, S. A review of recent advances in melamine detection techniques. J. Food Compos. Anal. 2015, 43, 25-38. [CrossRef]

16. Sun, F.; Ma, W.; Xu, L.; Zhu, Y.; Liu, L.; Peng, C.; Wang, L.; Kuang, H.; Xu, C. Analytical methods and recent developments in the detection of melamine. Trac Trend. Anal. Chem. 2010, 29, 1239-1249. [CrossRef]

17. Li, Y.; Xu, J.; Sun, C. Chemical sensors and biosensors for the detection of melamine. RSC Adv. 2015, 5, 1125-1147. [CrossRef]

18. Wang, T.; Ma, J.; Chen, Y.; Li, Y.; Zhang, L.; Zhang, Y. Analysis of melamine and analogs in complex matrices: Advances and trends. J. Separat. Sci. 2016, 40, 170-182. [CrossRef]

19. Brown, C.A.; Jeong, K.-S.; Poppenga, R.H.; Puschner, B.; Miller, D.M.; Ellis, A.E.; Kang, K.-I.; Sum, S.; Cistola, A.M.; Brown, S.A. Outbreaks of renal failure associated with melamine and cyanuric acid in dogs and cats in 2004 and 2007. J. Vet. Diagn. Investig. 2007, 19, 525-531. [CrossRef]

20. Gabriels, G.; Lambert, M.; Smith, P.; Wiesner, L.; Hiss, D. Melamine contamination in nutritional supplements-Is it an alarm bell for the general consumer, athletes, and 'Weekend Warriors'? Nutr. J. 2015, 14, 69. [CrossRef]

21. Wu, Y.; Zhang, Y. Analytical chemistry, toxicology, epidemiology and health impact assessment of melamine in infant formula: Recent progress and developments. Food Chem. Toxicol. 2013, 56, 325-335. [CrossRef]

22. Bates, F.; Busato, M.; Piletska, E.; Whitcombe, M.J.; Karim, K.; Guerreiro, A.; del Valle, M.; Giorgetti, A.; Piletsky, S. Computational design of molecularly imprinted polymer for direct detection of melamine in milk. Separ. Sci. Technol. 2017, 52, 1441-1453. [CrossRef]

23. Mauer, L.J.; Chernyshova, A.A.; Hiatt, A.; Deering, A.; Davis, R. Melamine detection in infant formula powder using Near- and Mid-Infrared spectroscopy. J. Agric. Food Chem. 2009, 57, 3974-3980. [CrossRef]

24. Lu, Y.; Xia, Y.; Liu, G.; Pan, M.; Li, M.; Lee, N.A.; Wang, S. A Review of Methods for Detecting Melamine in Food Samples. Crit. Rev. Anal. Chem. 2017, 47, 51-66. [CrossRef]

25. Tittlemier, S.A. Methods for the analysis of melamine and related compounds in foods: A review. Food Addit. Contamin. A 2010, 27, 129-145. [CrossRef] 
26. Lin, M.; He, L.; Awika, J.; Yang, L.; Ledoux, D.R.; Li, H.; Mustapha, A. Detection of melamine in gluten, chicken feed, and processed foods using surface enhanced Raman spectroscopy and HPLC. J. Food Sci. 2008, 73, T129-T134. [CrossRef] [PubMed]

27. Liu, Y.; Todd, E.E.D.; Zhang, Q.; Shi, J.-R.; Liu, X.-J. Recent developments in the detection of melamine. J. Zhejiang Univ. Sci. B 2012, 13, 525-532. [CrossRef] [PubMed]

28. Lin, M. A review of traditional and novel detection techniques for melamine and its analogues in foods and animal feed. Front. Chem. Eng. China 2009, 3, 427. [CrossRef]

29. Zhuang, H.; Zhu, W.; Yao, Z.; Li, M.; Zhao, Y. SERS-based sensing technique for trace melamine detection-A new method exploring. Talanta 2016, 153, 186-190. [CrossRef]

30. 30 Tsai, T.-H.; Thiagarajan, S.; Chen, S.-M. Detection of melamine in milk powder and human urine. J. Agric. Food Chem. 2010, 58, 4537-4544. [CrossRef]

31. Lu, Y.; Xia, Y.; Pan, M.; Wang, X.; Wang, S. Development of a surface plasmon resonance immunosensor for detecting melamine in milk products and Pet Foods. J. Agric. Food Chem. 2014, 62, 12471-12476. [CrossRef] [PubMed]

32. Filigenzi, M.S.; Tor, E.R.; Poppenga, R.H.; Aston, L.A.; Puschner, B. The determination of melamine in muscle tissue by liquid chromatography/tandem mass spectrometry. Rapid Commun. Mass Spectrom. 2007, 21, 4027-4032. [CrossRef] [PubMed]

33. Yang, S.; Ding, J.; Zheng, J.; Hu, B.; Li, J.; Chen, H.; Zhou, Z.; Qiao, X. Detection of melamine in milk products by surface desorption atmospheric pressure cemical ionization mass spectrometry. Anal. Chem. 2009, 81, 2426-2436. [CrossRef] [PubMed]

34. Jaleel, J.A.; Pramod, K. Artful and multifaceted applications of carbon dot in biomedicine. J. Cont. Release 2018, 269, 302-321. [CrossRef] [PubMed]

35. Lei, C.H.; Zhao, X.E.; Jiao, S.L.; He, L.; Li, Y.; Zhu, S.Y.; You, J.M. A turn-on fluorescent sensor for the detection of melamine based on the anti-quenching ability of $\mathrm{Hg}^{2+}$ to carbon nanodots. Anal. Methods 2016, 8, 4438-4444. [CrossRef]

36. Li, L.; Wu, G.; Hong, T.; Yin, Z.; Sun, D.; Abdel-Halim, E.S.; Zhu, J.-J. Graphene quantum dots as fluorescence probes for turn-off sensing of melamine in the presence of $\mathrm{Hg}^{2+}$. ACS Appl. Mater. Interfaces 2014, 6, 2858-2864. [CrossRef]

37. Zhang, M.; Ping, H.; Cao, X.; Li, H.; Guan, F.; Sun, C.; Liu, J. Rapid determination of melamine in milk using water-soluble CdTe quantum dots as fluorescence probes. Food Addit. Contamin. A 2012, 29, 333-344. [CrossRef]

38. Li, X.; Li, J.; Kuang, H.; Feng, L.; Yi, S.; Xia, X.; Huang, H.; Chen, Y.; Tang, C.; Zeng, Y. An ultrasensitive method for the determination of melamine using cadmium telluride quantum dots as fluorescence probes. Anal. Chim. Acta 2013, 802, 82-88. [CrossRef]

39. The Huy, B.; Seo, M.-H.; Zhang, X.; Lee, Y.-I. Selective optosensing of clenbuterol and melamine using molecularly imprinted polymer-capped CdTe quantum dots. Biosens. Bioelectron. 2014, 57, 310-316. [CrossRef]

40. $\mathrm{Xu}, \mathrm{S}$.; $\mathrm{Lu}, \mathrm{H}$. One-pot synthesis of mesoporous structured ratiometric fluorescence molecularly imprinted sensor for highly sensitive detection of melamine from milk samples. Biosens. Bioelectron. 2015, 73, 160-166. [CrossRef]

41. Zhang, L.; Chen, L. Visual detection of melamine by using a ratiometric fluorescent probe consisting of a red emitting CdTe core and a green emitting CdTe shell coated with a molecularly imprinted polymer. Microchim. Acta 2018, 185, 135. [CrossRef] [PubMed]

42. Wang, G.-L.; Jiao, H.-J.; Zhu, X.-Y.; Dong, Y.-M.; Li, Z.-J. Enhanced fluorescence sensing of melamine based on thioglycolic acid-capped CdS quantum dots. Talanta 2012, 93, 398-403. [CrossRef] [PubMed]

43. Cao, X.; Shen, F.; Zhang, M.; Guo, J.; Luo, Y.; Li, X.; Liu, H.; Sun, C.; Liu, J. Efficient inner filter effect of gold nanoparticles on the fluorescence of CdS quantum dots for sensitive detection of melamine in raw milk. Food Control 2013, 34, 221-229. [CrossRef]

44. Gong, Y.; Wu, H.; Fan, Z. Water-soluble Eu(iii)-doped ZnS quantum dots for the room-temperature phosphorescence detection of melamine in milk products. Anal. Methods 2013, 5, 6114-6119. [CrossRef]

45. Demirhan, B.E.; Demirhan, B.; Kara, H.E.S. Room-temperature phosphorescence determination of melamine in dairy products using l-cysteine-capped Mn-doped zinc sulfide (ZnS) quantum dots. J. Dairy Sci. 2015, 98, 2992-3000. [CrossRef] [PubMed] 
46. Liu, S.; Hu, J.; Zhang, H.; Su, X. CuInS 2 quantum dots-based fluorescence turn off/on probe for detection of melamine. Talanta 2012, 101, 368-373. [CrossRef] [PubMed]

47. Trapiella-Alfonso, L.; Costa-Fernandez, J.M.; Pereiro, R.; Sanz-Medel, A. Synthesis and characterization of hapten-quantum dots bioconjugates: Application to development of a melamine fluorescent immunoassay. Talanta 2013, 106, 243-248. [CrossRef] [PubMed]

48. Wu, J.; Xu, F.; Zhu, K.; Wang, Z.; Wang, Y.; Zhao, K.; Li, X.; Jiang, H.; Ding, S. Rapid and sensitive fluoroimmunoassay based on quantum dots for detection of melamine in milk. Anal. Lett. 2013, 46, 275-285. [CrossRef]

49. Dai, H.; Shi, Y.; Wang, Y.; Sun, Y.; Hu, J.; Ni, P.; Li, Z. Label-free turn-on fluorescent detection of melamine based on the anti-quenching ability of $\mathrm{Hg}^{2+}$ to gold nanoclusters. Biosens. Bioelectron. 2014, 53, 76-81. [CrossRef] [PubMed]

50. Yang, X.; Jia, Z.; Tan, Z.; Xu, H.; Luo, N.; Liao, X. Determination of melamine in infant formulas by fluorescence quenching based on the functionalized Au nanoclusters. Food Control 2016, 70, $286-292$. [CrossRef]

51. Cao, G.-X.; Wu, X.-M.; Dong, Y.-M.; Li, Z.-J.; Wang, G.-L. Colorimetric determination of melamine based on the reversal of the mercury(II) induced inhibition of the light-triggered oxidase-like activity of gold nanoclusters. Microchim. Acta 2016, 183, 441-448. [CrossRef]

52. Lee, C.-Y.; Hsu, N.-Y.; Wu, M.-Y.; Lin, Y.-W. Microwave-assisted synthesis of BSA-stabilised gold nanoclusters for the sensitive and selective detection of lead(ii) and melamine in aqueous solution. RSC Adv. 2016, 6, 79020-79027. [CrossRef]

53. Kalaiyarasan, G.; Anusuya, K.; Joseph, J. Melamine dependent fluorescence of glutathione protected gold nanoclusters and ratiometric quantification of melamine in commercial cow milk and infant formula. Appl. Surf. Sci. 2017, 420, 963-969. [CrossRef]

54. Lin, Y.-C.; Wu, T.; Lin, Y.-W. Fluorescence sensing of mercury(ii) and melamine in aqueous solutions through microwave-assisted synthesis of egg-white-protected gold nanoclusters. Anal. Methods 2018, 10, 1624-1632. [CrossRef]

55. Han, S.; Zhu, S.; Liu, Z.; Hu, L.; Parveen, S.; Xu, G. Oligonucleotide-stabilized fluorescent silver nanoclusters for turn-on detection of melamine. Biosens. Bioelectron. 2012, 36, 267-270. [CrossRef] [PubMed]

56. Du, Q.; Qu, F.; Mao, B.; Zhu, S.; You, J. Turn-on fluorescent detection of melamine based on Ag nanoclusters-Hg ${ }^{2+}$ system. New J. Chem. 2016, 40, 8459-8464. [CrossRef]

57. Ren, H.; Li, M.; Fu, Y.; Jin, L. Silver nanoclusters functionalized by chromotropic acid and layered double hydroxides for the turn-on detection of melamine. J. Mater. Chem. C 2016, 4, 6104-6109. [CrossRef]

58. Xie, P.; Zhan, Y.; Wu, M.; Guo, L.; Lin, Z.; Qiu, B.; Chen, G.; Cai, Z. The detection of melamine base on a turn-on fluorescence of DNA-Ag nanoclusters. J. Lumin. 2017, 186, 103-108. [CrossRef]

59. Ren, S.H.; Liu, S.G.; Ling, Y.; Li, N.B.; Luo, H.Q. Fluorescence detection of melamine based on inhibiting $\mathrm{Cu}^{2+}$-induced disaggregation of red-emitting silver nanoclusters. Spectrochim. Acta A 2018, 201, 112-118. [CrossRef] [PubMed]

60. Hou, X.; Wang, Q.; Mao, G.; Liu, H.; Yu, R.; Ren, X. Periodic silver nanocluster arrays over large-area silica nanosphere template as highly sensitive SERS substrate. Appl. Surf. Sci. 2018, 437, 92-97. [CrossRef]

61. Zhu, H.-W.; Dai, W.-X.; Yu, X.-D.; Xu, J.-J.; Chen, H.-Y. Poly thymine stabilized copper nanoclusters as a fluorescence probe for melamine sensing. Talanta 2015, 144, 642-647. [CrossRef] [PubMed]

62. Chen, L.-M.; Liu, Y.-N. Surface-enhanced Raman detection of melamine on silver-nanoparticle-decorated silver/carbon nanospheres: Effect of metal ions. ACS Appl. Mater. Interfaces 2011, 3, 3091-3096. [CrossRef] [PubMed]

63. Cao, X.; Shen, F.; Zhang, M.; Sun, C. Rapid and highly-sensitive melamine sensing based on the efficient inner filter effect of Ag nanoparticles on the fluorescence of eco-friendly ZnSe quantum dots. Sens. Actuators B 2014, 202, 1175-1182. [CrossRef]

64. Sarkar, S.; Dutta, S.; Pal, T. Tailored “Sandwich” strategy in surface enhanced Raman scattering: Case study with para-phenylenediamine and application in femtomolar detection of melamine. J. Phys. Chem. C 2014, 118, 28152-28161. [CrossRef]

65. Wu, W.; Liu, L.; Dai, Z.; Liu, J.; Yang, S.; Zhou, L.; Xiao, X.; Jiang, C.; Roy, V.A.L. Low-cost, disposable, flexible and highly reproducible screen printed SERS substrates for the detection of various chemicals. Sci. Rep. 2015, 5, 10208. [CrossRef] [PubMed] 
66. Wang, R.; Xu, Y.; Wang, R.; Wang, C.; Zhao, H.; Zheng, X.; Liao, X.; Cheng, L. A microfluidic chip based on an ITO support modified with Ag-Au nanocomposites for SERS based determination of melamine. Microchim. Acta 2017, 184, 279-287. [CrossRef]

67. Han, Y.; Liu, S.; Liu, B.; Jiang, C.; Zhang, Z. In situ loading of Ag nanocontacts onto silica nanospheres: A SERS platform for ultrasensitive detection. RSC Adv. 2014, 4, 2776-2782. [CrossRef]

68. Li, J.-M.; Ma, W.-F.; Wei, C.; You, L.-J.; Guo, J.; Hu, J.; Wang, C.-C. Detecting trace melamine in solution by SERS using Ag nanoparticle coated poly(styrene-co-acrylic acid) nanospheres as novel active substrates. Langmuir 2011, 27, 14539-14544. [CrossRef]

69. Henry, A.-I.; Sharma, B.; Cardinal, M.F.; Kurouski, D.; Van Duyne, R.P. Surface-enhanced Raman spectroscopy biosensing: In vivo diagnostics and multimodal imaging. Anal. Chem. 2016, 88, 6638-6647. [CrossRef]

70. Wang, W.-F.; Qiang, Y.; Meng, X.-H.; Yang, J.-L.; Shi, Y.-P. Ultrasensitive colorimetric assay melamine based on in situ reduction to formation of CQDs-silver nanocomposite. Sens. Actuators B 2018, 260, 808-815. [CrossRef]

71. Tang, L.; Mo, S.; Liu, S.G.; Ling, Y.; Zhang, X.F.; Li, N.B.; Luo, H.Q. A Sensitive “turn-on" fluorescent sensor for melamine based on FRET effect between polydopamine-glutathione nanoparticles and Ag nanoparticles. J. Agric. Food Chem. 2018, 66, 2174-2179. [CrossRef] [PubMed]

72. Manzoori, J.L.; Amjadi, M.; Hassanzadeh, J. Enhancement of the chemiluminescence of permanganate-formaldehyde system by gold/silver nanoalloys and its application to trace determination of melamine. Microchim. Acta 2011, 175, 47. [CrossRef]

73. Zhang, M.; Cao, X.; Li, H.; Guan, F.; Guo, J.; Shen, F.; Luo, Y.; Sun, C.; Zhang, L. Sensitive fluorescent detection of melamine in raw milk based on the inner filter effect of Au nanoparticles on the fluorescence of CdTe quantum dots. Food Chem. 2012, 135, 1894-1900. [CrossRef] [PubMed]

74. Yue, J.; Jiang, X.; Kaneti, Y.V.; Yu, A. Deposition of gold nanoparticles on $\beta$-FeOOH nanorods for detecting melamine in aqueous solution. J. Colloid Interface Sci. 2012, 367, 204-212. [CrossRef] [PubMed]

75. Chen, N.; Cheng, Y.; Li, C.; Zhang, C.; Zhao, K.; Xian, Y. Determination of melamine in food contact materials using an electrode modified with gold nanoparticles and reduced graphene oxide. Microchim. Acta 2015, 182, 1967-1975. [CrossRef]

76. Shen, J.; Yang, Y.; Zhang, Y.; Yang, H.; Zhou, Z.; Yang, S. Functionalized Au-Fe ${ }_{3} \mathrm{O}_{4}$ nanocomposites as a magnetic and colorimetric bimodal sensor for melamine. Sens. Actuators B 2016, 226, 512-517. [CrossRef]

77. Peng, J.; Feng, Y.; Han, X.-X.; Gao, Z.-N. Sensitive electrochemical detection of melamine based on gold nanoparticles deposited on a graphene doped carbon paste electrode. Anal. Methods 2016, 8, $2526-2532$. [CrossRef]

78. Neng, J.; Tan, J.; Jia, K.; Sun, P. A fast and cost-effective detection of melamine by surface enhanced Raman spectroscopy using a novel hydrogen bonding-assisted supramolecular matrix and gold-coated magnetic nanoparticles. Appl. Sci. 2017, 7, 475. [CrossRef]

79. Rao, H.; Chen, M.; Ge, H.; Lu, Z.; Liu, X.; Zou, P.; Wang, X.; He, H.; Zeng, X.; Wang, Y. A novel electrochemical sensor based on Au@PANI composites film modified glassy carbon electrode binding molecular imprinting technique for the determination of melamine. Biosens. Bioelectron. 2017, 87, 1029-1035. [CrossRef]

80. Niu, C.; Liu, Q.; Shang, Z.; Zhao, L.; Ouyang, J. Dual-emission fluorescent sensor based on AIE organic nanoparticles and Au nanoclusters for the detection of mercury and melamine. Nanoscale 2015, 7, 8457-8465. [CrossRef]

81. Dey, M.K.; Reddy, A.V.R.; Satpati, A.K. Determination of melamine by a reduced graphene oxide-gold nanoparticle composite carbon paste electrode. Anal. Lett. 2016, 49, 2703-2715. [CrossRef]

82. Lv, L.; Li, J.; Fang, W.; Shen, A.; Hu, J. A tip-gap mesh-like bilayer SERS substrate for highly sensitive detection. Anal. Methods 2018, 10, 2251-2256. [CrossRef]

83. Dai, H.; Shi, Y.; Wang, Y.; Sun, Y.; Hu, J.; Ni, P.; Li, Z. A carbon dot based biosensor for melamine detection by fluorescence resonance energy transfer. Sens. Actuators B 2014, 202, 201-208. [CrossRef]

84. Qu, F.; Xu, X.; You, J. A new dual-emission fluorescence sensor based on carbon nanodots and gold nanoclusters for the detection of melamine. New J. Chem. 2017, 41, 9438-9443. [CrossRef]

85. Rovina, K.; Siddiquee, S. Electrochemical sensor based rapid determination of melamine using ionic liquid/zinc oxide nanoparticles/chitosan/gold electrode. Food Control 2016, 59, 801-808. [CrossRef] 
86. Gao, F.; Ye, Q.; Cui, P.; Zhang, L. Efficient fluorescence energy transfer system between CdTe-doped silica nanoparticles and gold nanoparticles for turn-on fluorescence detection of melamine. J. Agric. Food Chem. 2012, 60, 4550-4558. [CrossRef] [PubMed]

87. Tang, G.; Du, L.; Su, X. Detection of melamine based on the fluorescence resonance energy transfer between CdTe QDs and Rhodamine B. Food Chem. 2013, 141, 4060-4065. [CrossRef] [PubMed]

88. Zhao, J.; Wu, H.; Jiang, J.; Zhao, S. Label-free fluorescence turn-on sensing for melamine based on fluorescence resonance energy transfer between CdTe/CdS quantum dots and gold nanoparticles. RSC Adv. 2014, 4, 61667-61672. [CrossRef]

89. Zhu, J.; Chang, H.; Li, J.-J.; Li, X.; Zhao, J.-W. Dual-mode melamine detection based on gold nanoparticles aggregation-induced fluorescence "turn-on" and "turn-off" of CdTe quantum dots. Sens. Actuators B 2017, 239, 906-915. [CrossRef]

90. Fu, X.; Gu, Z.; Lu, Q.; Liao, J.; Chen, S. A solid-state electrochemiluminescent sensor based on C60/graphite-like carbon nitride nanosheet hybrids for detecting melamine. RSC Adv. 2016, 6, 13217-13223. [CrossRef]

91. Lian, S.; Huang, Z.; Lin, Z.; Chen, X.; Oyama, M.; Chen, X. A highly selective melamine sensor relying on intensified electrochemiluminescence of the silica nanoparticles doped with $\left[\mathrm{Ru}(\mathrm{bpy})_{3}\right]^{2+} /$ molecularly imprinted polymer modified electrode. Sens. Actuators B 2016, 236, 614-620. [CrossRef]

92. Zhang, W.; Xu, G.; Liu, R.; Chen, J.; Li, X.; Zhang, Y.; Zhang, Y. Novel MOFs@XC-72-nafion nanohybrid modified glassy carbon electrode for the sensitive determination of melamine. Electrochim. Acta 2016, 211, 689-696. [CrossRef]

93. Jin, X.; Yin, W.; Ni, G.; Peng, J. Hydrogen-bonding-induced colorimetric detection of melamine based on the peroxidase activity of gelatin-coated cerium oxide nanospheres. Anal. Methods 2018, 10, 841-847. [CrossRef]

94. Honarvar, Z.; Hadian, Z.; Mashayekh, M. Nanocomposites in food packaging applications and their risk assessment for health. Electron. Physician 2016, 8, 2531-2538. [CrossRef] [PubMed]

95. Chen, H.-Q.; Wu, Y.; Yuan, F.; Xu, J.; Zhang, Y.-Y.; Wang, L. Inner filter effect of gold nanoparticles on the fluorescence of rare-earth phosphate nanocrystals and its application for determination of biological aminothiols. J. Lumin. 2013, 141, 33-37. [CrossRef]

96. Hazra, C.; Adusumalli, V.N.K.B.; Mahalingam, V.3,5-Dinitrobenzoic acid-capped upconverting nanocrystals for the selective detection of melamine. ACS Appl. Mater. Interfaces 2014, 6, 7833-7839. [CrossRef] [PubMed]

97. Vilela, D.; González, M.C.; Escarpa, A. Sensing colorimetric approaches based on gold and silver nanoparticles aggregation: Chemical creativity behind the assay. A review. Anal. Chim. Acta 2012, 751, $24-43$. [CrossRef] [PubMed]

98. Zhou, Q.; Liu, N.; Qie, Z.; Wang, Y.; Ning, B.; Gao, Z. Development of gold nanoparticle-based rapid detection kit for melamine in milk products. J. Agric. Food Chem. 2011, 59, 12006-12011. [CrossRef]

99. Ni, P.; Dai, H.; Wang, Y.; Sun, Y.; Shi, Y.; Hu, J.; Li, Z. Visual detection of melamine based on the peroxidase-like activity enhancement of bare gold nanoparticles. Biosens. Bioelectron. 2014, 60, 286-291. [CrossRef]

100. Chen, W.; Deng, H.-H.; Hong, L.; Wu, Z.-Q.; Wang, S.; Liu, A.-L.; Lin, X.-H.; Xia, X.-H. Bare gold nanoparticles as facile and sensitive colorimetric probe for melamine detection. Analyst 2012, 137, 5382-5386. [CrossRef]

101. Guo, L.; Zhong, J.; Wu, J.; Fu, F.; Chen, G.; Zheng, X.; Lin, S. Visual detection of melamine in milk products by label-free gold nanoparticles. Talanta 2010, 82, 1654-1658. [CrossRef] [PubMed]

102. Chi, H.; Liu, B.; Guan, G.; Zhang, Z.; Han, M.-Y. A simple, reliable and sensitive colorimetric visualization of melamine in milk by unmodified gold nanoparticles. Analyst 2010, 135, 1070-1075. [CrossRef] [PubMed]

103. Li, L.; Li, B.; Cheng, D.; Mao, L. Visual detection of melamine in raw milk using gold nanoparticles as colorimetric probe. Food Chem. 2010, 122, 895-900. [CrossRef]

104. Xiang, D.; Zeng, G.; Zhai, K.; Li, L.; He, Z. Determination of melamine in milk powder based on the fluorescence enhancement of Au nanoparticles. Analyst 2011, 136, 2837-2844. [CrossRef] [PubMed]

105. Zeng, S.; Cai, M.; Liang, H.; Hao, J. Size-dependent colorimetric visual detection of melamine in milk at $10 \mathrm{ppb}$ level by citrate-stabilized Au nanoparticles. Anal. Methods 2012, 4, 2499-2505. [CrossRef]

106. Kumar, N.; Seth, R.; Kumar, H. Colorimetric detection of melamine in milk by citrate-stabilized gold nanoparticles. Anal. Biochem. 2014, 456, 43-49. [CrossRef] [PubMed]

107. Xie, W.; Huang, Y.; Yun, W.; Tang, D.; Zhang, H.; Du, C.; Zhu, Y.; Zhang, W. Simple pretreatment and portable UV-Vis spectrum instrument for the rapid detection of melamine in milk products. J. Food Qual. 2015, 38, 297-304. [CrossRef] 
108. Paul, I.E.; Rajeshwari, A.; Prathna, T.C.; Raichur, A.M.; Chandrasekaran, N.; Mukherjee, A. Colorimetric detection of melamine based on the size effect of AuNPs. Anal. Methods 2015, 7, 1453-1462. [CrossRef]

109. Zhang, L.; Yuan, Y.; Wen, X.; Li, Y.; Cao, C.; Xiong, Q. A coordination and ligand replacement based three-input colorimetric logic gate sensing platform for melamine, mercury ions, and cysteine. RSC Adv. 2015, 5, 59106-59113. [CrossRef]

110. Wei, F.; Lam, R.; Cheng, S.; Lu, S.; Ho, D.; Li, N. Rapid detection of melamine in whole milk mediated by unmodified gold nanoparticles. Appl. Phys. Lett. 2010, 96, 133702. [CrossRef]

111. Bai, L.-Y.; Dong, C.-X.; Zhang, Y.-P.; Li, W.; Chen, J. Comparative studies on the quick recognition of melamine using unmodified gold nanoparticles and p-nitrobenzenesulfonic grafted silver nanoparticles. J. Chin. Chem. Soc. 2011, 58, 846-852. [CrossRef]

112. Xing, H.-B.; Wu, Y.-G.; Zhan, S.-S.; Zhou, P. A Rapid colorimetric detection of melamine in raw milk by unmodified gold nanoparticles. Food Anal. Methods 2013, 6, 1441-1447. [CrossRef]

113. Kumar, P.; Kumar, P.; Manhas, S.; Navani, N.K. A simple method for detection of anionic detergents in milk using unmodified gold nanoparticles. Sens. Actuators B 2016, 233, 157-161. [CrossRef]

114. Lu, Q.; Zhao, J.; Xue, S.; Yin, P.; Zhang, Y.; Yao, S. A “turn-on" fluorescent sensor for ultrasensitive detection of melamine based on a new fluorescence probe and AuNPs. Analyst 2015, 140, 1155-1160. [CrossRef] [PubMed]

115. Paul, I.E.; Rajeshwari, A.; Satija, J.; Raichur, A.M.; Chandrasekaran, N.; Mukherjee, A. Fluorescence based study for melamine detection using gold colloidal solutions. J. Fluoresc. 2016, 26, 2225-2235. [CrossRef] [PubMed]

116. Huang, H.; Li, L.; Zhou, G.; Liu, Z.; Ma, Q.; Feng, Y.; Zeng, G.; Tinnefeld, P.; He, Z. Visual detection of melamine in milk samples based on label-free and labeled gold nanoparticles. Talanta 2011, 85, 1013-1019. [CrossRef] [PubMed]

117. Ai, K.; Liu, Y.; Lu, L. Hydrogen-bonding recognition-induced color change of gold nanoparticles for visual detection of melamine in raw milk and infant formula. J. Am. Chem. Soc. 2009, 131, 9496-9497. [CrossRef] [PubMed]

118. Cao, Q.; Zhao, H.; He, Y.; Li, X.; Zeng, L.; Ding, N.; Wang, J.; Yang, J.; Wang, G. Hydrogen-bonding-induced colorimetric detection of melamine by nonaggregation-based Au-NPs as a probe. Biosens. Bioelectron. 2010, 25, 2680-2685. [CrossRef]

119. Chang, C.-W.; Chu, S.-P.; Tseng, W.-L. Selective extraction of melamine using 11-mercaptoundecanoic acid-capped gold nanoparticles followed by capillary electrophoresis. J. Chromatogr. A 2010, 1217, 7800-7806. [CrossRef]

120. Qi, W.J.; Wu, D.; Ling, J.; Huang, C.Z. Visual and light scattering spectrometric detections of melamine with polythymine-stabilized gold nanoparticles through specific triple hydrogen-bonding recognition. Chem. Commun. 2010, 46, 4893-4895. [CrossRef]

121. Kuang, H.; Chen, W.; Yan, W.; Xu, L.; Zhu, Y.; Liu, L.; Chu, H.; Peng, C.; Wang, L.; Kotov, N.A.; et al. Crown ether assembly of gold nanoparticles: Melamine sensor. Biosens. Bioelectron. 2011, 26, 2032-2037. [CrossRef] [PubMed]

122. Liang, X.; Wei, H.; Cui, Z.; Deng, J.; Zhang, Z.; You, X.; Zhang, X.-E. Colorimetric detection of melamine in complex matrices based on cysteamine-modified gold nanoparticles. Analyst 2011, 136, 179-183. [CrossRef] [PubMed]

123. Guo, L.; Zhong, J.; Wu, J.; Fu, F.; Chen, G.; Chen, Y.; Zheng, X.; Lin, S. Sensitive turn-on fluorescent detection of melamine based on fluorescence resonance energy transfer. Analyst 2011, 136, 1659-1663. [CrossRef] [PubMed]

124. Su, H.; Fan, H.; Ai, S.; Wu, N.; Fan, H.; Bian, P.; Liu, J. Selective determination of melamine in milk samples using 3-mercapto-1-propanesulfonate-modified gold nanoparticles as colorimetric probe. Talanta 2011, 85, 1338-1343. [CrossRef] [PubMed]

125. Lou, T.; Wang, Y.; Li, J.; Peng, H.; Xiong, H.; Chen, L. Rapid detection of melamine with 4-mercaptopyridine-modified gold nanoparticles by surface-enhanced Raman scattering. Anal. Bioanal. Chem. 2011, 401, 333-338. [CrossRef] [PubMed]

126. Wu, Z.; Zhao, H.; Xue, Y.; Cao, Q.; Yang, J.; He, Y.; Li, X.; Yuan, Z. Colorimetric detection of melamine during the formation of gold nanoparticles. Biosens. Bioelectron. 2011, 26, 2574-2578. [CrossRef] [PubMed] 
127. Roy, B.; Saha, A.; Nandi, A.K. Melamine sensing through riboflavin stabilized gold nanoparticles. Analyst 2011, 136, 67-70. [CrossRef] [PubMed]

128. Liang, A.; Zhou, L.; Qin, H.; Zhang, Y.; Ouyang, H.; Jiang, Z. A Highly sensitive aptamer-nanogold catalytic resonance scattering spectral assay for melamine. J. Fluoresc. 2011, 21, 1907-1912. [CrossRef] [PubMed]

129. Shen, S.F.; Zhao, H.W.; Xu, D.; Wu, L.P.; Huang, C.Z. Colorimetric assay of melamine based on the aggregation of gold nanoparticles. J. Biomed. Nanotechnol. 2011, 7, 691-695. [CrossRef]

130. Bera, R.K.; Raj, C.R. Naked eye sensing of melamine using rationally tailored gold nanoparticles: Hydrogen-bonding and charge-transfer recognition. Analyst 2011, 136, 1644-1648. [CrossRef]

131. Sun, F.; Liu, L.; Ma, W.; Xu, C.; Wang, L.; Kuang, H. Rapid on-site determination of melamine in raw milk by an immunochromatographic strip. Int. J. Food Sci. Technol. 2012, 47, 1505-1510. [CrossRef]

132. Wu, Z.; Zhao, H.; Xue, Y.; He, Y.; Li, X.; Yuan, Z. Colorimetric Determination of Melamine by Pyridine-3-Boronic Acid Modified Gold Nanoparticles. J. Nanosci. Nanotechnol. 2012, 12, 2412-2416. [CrossRef] [PubMed]

133. Yazgan, N.N.; Boyac1, İ.H.; Topcu, A.; Tamer, U. Detection of melamine in milk by surface-enhanced Raman spectroscopy coupled with magnetic and Raman-labeled nanoparticles. Anal. Bioanal. Chem. 2012, 403, 2009-2017. [CrossRef] [PubMed]

134. Vasimalai, N.; Abraham John, S. Picomolar melamine enhanced the fluorescence of gold nanoparticles: Spectrofluorimetric determination of melamine in milk and infant formulas using functionalized triazole capped goldnanoparticles. Biosens. Bioelectron. 2013, 42, 267-272. [CrossRef] [PubMed]

135. Xing, H.; Zhan, S.; Wu, Y.; He, L.; Zhou, P. Sensitive colorimetric detection of melamine in milk with an aptamer-modified nanogold probe. RSC Adv. 2013, 3, 17424-17430. [CrossRef]

136. Ma, Y.; Jiang, L.; Mei, Y.; Song, R.; Tian, D.; Huang, H. Colorimetric sensing strategy for mercury(ii) and melamine utilizing cysteamine-modified gold nanoparticles. Analyst 2013, 138, 5338-5343. [CrossRef] [PubMed]

137. Zhang, X.; Wu, Z.; Xue, Y.; Zhang, Y.; Zhao, H.; He, Y.; Li, X.; Yuan, Z. Colorimetric detection of melamine based on the interruption of the synthesis of gold nanoparticles. Anal. Methods 2013, 5, 1930-1934. [CrossRef]

138. Yun, W.; Li, H.; Chen, S.; Tu, D.; Xie, W.; Huang, Y. Aptamer-based rapid visual biosensing of melamine in whole milk. Eur. Food Res. Technol. 2014, 238, 989-995. [CrossRef]

139. Du, J.; Wang, Y.; Zhang, W. Gold nanoparticles-based chemiluminescence resonance energy transfer for ultrasensitive detection of melamine. Spectrochim. Acta A 2015, 149, 698-702. [CrossRef]

140. Wu, L.; Chen, K.; Lu, Z.; Li, T.; Shao, K.; Shao, F.; Han, H. Hydrogen-bonding recognition-induced aggregation of gold nanoparticles for the determination of the migration of melamine monomers using dynamic light scattering. Anal. Chim. Acta 2014, 845, 92-97. [CrossRef]

141. Wang, H.; Guo, X.; Fu, S.; Yang, T.; Wen, Y.; Yang, H. Raman probing trace melamine in milk by a functionalized test paper. Sens. Actuators B 2014, 193, 630-636. [CrossRef]

142. Cai, H.-H.; Yu, X.; Dong, H.; Cai, J.; Yang, P.-H. Visual and absorption spectroscopic detections of melamine with 3-mercaptopriopionic acid-functionalized gold nanoparticles: A synergistic strategy induced nanoparticle aggregates. J. Food Eng. 2014, 142, 163-169. [CrossRef]

143. Cao, X.; Shen, F.; Zhang, M.; Guo, J.; Luo, Y.; Xu, J.; Li, Y.; Sun, C. Highly sensitive detection of melamine based on fluorescence resonance energy transfer between rhodamine B and gold nanoparticles. Dye. Pigment. 2014, 111, 99-107. [CrossRef]

144. Le, L.T.; Nguyen, H.-P.; Dinh, Q.-K.; Hoang, T.-L.; Nguyen, Q.-H.; Tran, T.-H.; Nguyen, T.-D. Water-soluble acetylated chitosan-stabilized gold nanosphere bioprobes. Mater. Chem. Phys. 2015, 149-150, 324-332. [CrossRef]

145. Xiao, C.; Zhang, X.; Liu, J.; Yang, A.; Zhao, H.; Li, X.; He, Y.; Yuan, Z. Sensitive colorimetric detection of melamine with 1,4-dithiothreitol modified gold nanoparticles. Anal. Methods 2015, 7, 924-929. [CrossRef]

146. Xin, J.-Y.; Zhang, L.-X.; Chen, D.-D.; Lin, K.; Fan, H.-C.; Wang, Y.; Xia, C.-G. Colorimetric detection of melamine based on methanobactin-mediated synthesis of gold nanoparticles. Food Chem. 2015, 174, 473-479. [CrossRef] [PubMed]

147. Du, J.; Wang, Z.; Peng, X.; Fan, J. In situ colorimetric recognition of melamine based on thymine derivative-functionalized gold nanoparticle. Ind. Eng. Chem. Res. 2015, 54, 12011-12016. [CrossRef]

148. Yin, M.; Zhao, L.; Wei, Q.; Li, H. Rapid colorimetric detection of melamine by $\mathrm{H}_{2} \mathrm{O}_{2}-\mathrm{Au}$ nanoparticles. RSC Adv. 2015, 5, 32897-32901. [CrossRef] 
149. Wu, Q.; Long, Q.; Li, H.; Zhang, Y.; Yao, S. An upconversion fluorescence resonance energy transfer nanosensor for one step detection of melamine in raw milk. Talanta 2015, 136, 47-53. [CrossRef]

150. Wang, X.; Pauli, J.; Niessner, R.; Resch-Genger, U.; Knopp, D. Gold nanoparticle-catalyzed uranine reduction for signal amplification in fluorescent assays for melamine and aflatoxin B1. Analyst 2015, 140, 7305-7312. [CrossRef]

151. Dong, N.; Hu, Y.; Yang, K.; Liu, J. Development of aptamer-modified SERS nanosensor and oligonucleotide chip to quantitatively detect melamine in milk with high sensitivity. Sens. Actuators B 2016, 228, 85-93. [CrossRef]

152. Li, J.; Huang, P.; Wu, F. Colorimetric detection of melamine based on p-chlorobenzenesulfonic acid-modified AuNPs. J. Nanopart. Res. 2016, 18, 156. [CrossRef]

153. Zhong, Y.; Chen, Y.; Yao, L.; Zhao, D.; Zheng, L.; Liu, G.; Ye, Y.; Chen, W. Gold nanoparticles based lateral flow immunoassay with largely amplified sensitivity for rapid melamine screening. Microchim. Acta 2016, 183, 1989-1994. [CrossRef]

154. Chang, K.; Wang, S.; Zhang, H.; Guo, Q.; Hu, X.; Lin, Z.; Sun, H.; Jiang, M.; Hu, J. Colorimetric detection of melamine in milk by using gold nanoparticles-based LSPR via optical fibers. PLoS ONE 2017, 12, e0177131. [CrossRef] [PubMed]

155. Zheng, H.; Li, Y.; Xu, J.; Bie, J.; Liu, X.; Guo, J.; Luo, Y.; Shen, F.; Sun, C.; Yu, Y. Highly sensitive aptamer-based colorimetric detection of melamine in raw milk with cysteamine-stabilized gold nanoparticles. J. Nanosci. Nanotechnol. 2017, 17, 853-861. [CrossRef] [PubMed]

156. Anand, K.; Singh, T.; Madhumitha, G.; Phulukdaree, A.; Gengan, R.M.; Chuturgoon, A.A. Biosynthesis and computational analysis of amine-ended dual thiol ligand functionalized gold nanoparticles for conventional spectroscopy detection of melamine. J. Photochem. Photobiol. B 2017, 169, 75-82. [CrossRef] [PubMed]

157. Xiong, Z.; Chen, X.; Liou, P.; Lin, M. Development of nanofibrillated cellulose coated with gold nanoparticles for measurement of melamine by SERS. Cellulose 2017, 24, 2801-2811. [CrossRef]

158. Gao, N.; Huang, P.; Wu, F. Colorimetric detection of melamine in milk based on Triton X-100 modified gold nanoparticles and its paper-based application. Spectrochim. Acta A 2018, 192, 174-180. [CrossRef]

159. Liang, L.; Zhen, S.; Huang, C. Visual and light scattering spectrometric method for the detection of melamine using uracil 5'-triphosphate sodium modified gold nanoparticles. Spectrochim. Acta A 2017, 173, 99-104. [CrossRef]

160. Mecker, L.C.; Tyner, K.M.; Kauffman, J.F.; Arzhantsev, S.; Mans, D.J.; Gryniewicz-Ruzicka, C.M. Selective melamine detection in multiple sample matrices with a portable Raman instrument using surface enhanced Raman spectroscopy-active gold nanoparticles. Anal. Chim. Acta 2012, 733, 48-55. [CrossRef]

161. Roy, P.K.; Huang, Y.-F.; Chattopadhyay, S. In Detection of melamine on fractals of unmodified gold nanoparticles by surface-enhanced Raman scattering. J. Biomed. Opt. 2014, 19, 011002. [CrossRef] [PubMed]

162. Giovannozzi, A.M.; Rolle, F.; Sega, M.; Abete, M.C.; Marchis, D.; Rossi, A.M. Rapid and sensitive detection of melamine in milk with gold nanoparticles by surface enhanced Raman scattering. Food Chem. 2014, 159, 250-256. [CrossRef] [PubMed]

163. Lang, T.; Pang, S.; He, L. Integration of colorimetric and SERS detection for rapid screening and validation of melamine in milk. Anal. Methods 2015, 7, 6426-6431. [CrossRef]

164. Hsieh, Y.-T.; Chen, W.-T.; Tomalová, I.; Preisler, J.; Chang, H.-T. Detection of melamine in infant formula and grain powder by surface-assisted laser desorption/ionization mass spectrometry. Rapid Commun.Mass Spectrom. 2012, 26, 1393-1398. [CrossRef] [PubMed]

165. Liu, J.; Feng, S.; Shi, Y.; Lyu, J.; Lv, J. Sensitive and simple sonoluminescence detection of melamine via aggregation of Au nanoparticles. Anal. Methods 2015, 7, 5162-5168. [CrossRef]

166. Li, R.; Yang, G.; Yang, J.; Han, J.; Liu, J.; Huang, M. Determination of melamine in milk using surface plasma effect of aggregated Au@SiO2 nanoparticles by SERS technique. Food Control 2016, 68, 14-19. [CrossRef]

167. Sabela, M.; Balme, S.; Bechelany, M.; Janot, J.-M.; Bisetty, K. A Review of gold and silver nanoparticle-based colorimetric sensing assays. Adv. Eng. Mater. 2017, 19, 1700270. [CrossRef]

168. Ping, H.; Zhang, M.; Li, H.; Li, S.; Chen, Q.; Sun, C.; Zhang, T. Visual detection of melamine in raw milk by label-free silver nanoparticles. Food Control 2012, 23, 191-197. [CrossRef]

169. Wang, H.; Chen, D.; Yu, L.; Chang, M.; Ci, L. One-step, room temperature, colorimetric melamine sensing using an in-situ formation of silver nanoparticles through modified Tollens process. Spectrochim. Acta A 2015, 137, 281-285. [CrossRef] 
170. Kumar, N.; Kumar, H.; Mann, B.; Seth, R. Colorimetric determination of melamine in milk using unmodified silver nanoparticles. Spectrochim. Acta A 2016, 156, 89-97. [CrossRef]

171. Bittar, D.B.; Catelani, T.A.; Nigoghossian, K.; Barud, H. d. S.; Ribeiro, S.J.L.; Pezza, L.; Pezza, H.R. Optimized synthesis of silver nanoparticles by factorial design with application for the determination of melamine in milk. Anal. Lett. 2017, 50, 829-841. [CrossRef]

172. Han, C.; Li, H. Visual detection of melamine in infant formula at $0.1 \mathrm{ppm}$ level based on silver nanoparticles. Analyst 2010, 135, 583-588. [CrossRef] [PubMed]

173. Ma, Y.; Niu, H.; Zhang, X.; Cai, Y. One-step synthesis of silver/dopamine nanoparticles and visual detection of melamine in raw milk. Analyst 2011, 136, 4192-4196. [CrossRef] [PubMed]

174. Liang, A.; Zhou, L.; Jiang, Z. A Simple and sensitive resonance scattering spectral assay for detection of melamine using aptamer-modified nanosilver probe. Plasmonics 2011, 6, 387-392. [CrossRef]

175. Liu, Y.; Zhang, Y.; Ding, H.; Xu, S.; Li, M.; Kong, F.; Luo, Y.; Li, G. Self-assembly of noble metallic spherical aggregates from monodisperse nanoparticles: Their synthesis and pronounced SERS and catalytic properties. J. Mater. Chem. A 2013, 1, 3362-3371. [CrossRef]

176. John Xavier, S.S.; Karthikeyan, C.; Gnana kumar, G.; Kim, A.R.; Yoo, D.J. Colorimetric detection of melamine using $\beta$-cyclodextrin-functionalized silver nanoparticles. Anal. Methods 2014, 6, 8165-8172. [CrossRef]

177. Song, J.; Wu, F.; Wan, Y.; Ma, L.-H. Visual test for melamine using silver nanoparticles modified with chromotropic acid. Microchim. Acta 2014, 181, 1267-1274. [CrossRef]

178. Song, J.; Wu, F.; Wan, Y.; Ma, L. Colorimetric detection of melamine in pretreated milk using silver nanoparticles functionalized with sulfanilic acid. Food Control 2015, 50, 356-361. [CrossRef]

179. Zhao, Y.; Tian, Y.; Ma, P.; Yu, A.; Zhang, H.; Chen, Y. Determination of melamine and malachite green by surface-enhanced Raman scattering spectroscopy using starch-coated silver nanoparticles as substrates. Anal. Methods 2015, 7, 8116-8122. [CrossRef]

180. Borase, H.P.; Patil, C.D.; Salunkhe, R.B.; Suryawanshi, R.K.; Salunke, B.K.; Patil, S.V. Biofunctionalized silver nanoparticles as a novel colorimetric probe for melamine detection in raw milk. Biotechnol. Appl. Biochem. 2014, 62, 652-662. [CrossRef]

181. Kaleeswaran, P.; Nandhini, T.; Pitchumani, K. Naked eye sensing of melamine: Aggregation induced recognition by sodium d-gluconate stabilised silver nanoparticles. New J. Chem. 2016, 40, 3869-3874. [CrossRef]

182. Zhu, X.; Xiao, Y.; Jiang, X.; Li, J.; Qin, H.; Huang, H.; Zhang, Y.; He, X.; Wang, K. A ratiometric nanosensor based on conjugated polyelectrolyte-stabilized AgNPs for ultrasensitive fluorescent and colorimetric sensing of melamine. Talanta 2016, 151, 68-74. [CrossRef] [PubMed]

183. Ramalingam, K.; Devasena, T.; Senthil, B.; Kalpana, R.; Jayavel, R. Silver nanoparticles for melamine detection in milk based on transmitted light intensity. IET Sci. Meas. Technol. 2017, 11, 171-178. [CrossRef]

184. Li, R.; Yang, J.; Han, J.; Liu, J.; Huang, M. Quantitative determination of melamine in milk using Ag nanoparticle monolayer film as SERS substrate. Phys. E 2017, 88, 164-168. [CrossRef]

185. Alam, M.F.; Laskar, A.A.; Ahmed, S.; Shaida, M.A.; Younus, H. Colorimetric method for the detection of melamine using in-situ formed silver nanoparticles via tannic acid. Spectrochim. Acta A 2017, 183, 17-22. [CrossRef] [PubMed]

186. Daniel, S.C.G.K.; Nirupa Julius, L.A.; Gorthi, S.S. Instantaneous detection of melamine by interference biosynthesis of silver nanoparticles. Sens. Actuators B 2017, 238, 641-650. [CrossRef]

187. Varun, S.; Kiruba Daniel, S.C.G.; Gorthi, S.S. Rapid sensing of melamine in milk by interference green synthesis of silver nanoparticles. Mater. Sci. Eng. C 2017, 74, 253-258. [CrossRef] [PubMed]

188. Zhang, B.; Xu, P.; Xie, X.; Wei, H.; Li, Z.; Mack, N.H.; Han, X.; Xu, H.; Wang, H.-L. Acid-directed synthesis of SERS-active hierarchical assemblies of silver nanostructures. J. Mater. Chem. 2011, 21, 2495-2501. [CrossRef]

189. Li, D.; Lv, D.Y.; Zhu, Q.X.; Li, H.; Chen, H.; Wu, M.M.; Chai, Y.F.; Lu, F. Chromatographic separation and detection of contaminants from whole milk powder using a chitosan-modified silver nanoparticles surface-enhanced Raman scattering device. Food Chem. 2017, 224, 382-389. [CrossRef]

190. Li, J.; Zhang, G.; Wang, L.; Shen, A.; Hu, J. Simultaneous enzymatic and SERS properties of bifunctional chitosan-modified popcorn-like Au-Ag nanoparticles for high sensitive detection of melamine in milk powder. Talanta 2015, 140, 204-211. [CrossRef]

191. Deng, S.Q.; Zou, H.Y.; Lan, J.; Huang, C.Z. Aggregation-induced superior peroxidase-like activity of $\mathrm{Cu}_{2-x} \mathrm{Se}$ nanoparticles for melamine detection. Anal. Methods 2016, 8, 7516-7521. [CrossRef] 
192. Wang, Z.; Zhi, D.; Zhang, H.; Zhao, Y.; Che, J.; Bao, Y.; Wang, X.; Li, H. Synthesis of selenium nanoparticles suitable for melamine detection using test strips. Nanosci. Nanotechnol. Lett. 2015, 7, 617-622. [CrossRef]

193. Shen, J.; Zhang, Y.; Yang, H.; Yang, Y.; Zhou, Z.; Yang, S. Detection of melamine by a magnetic relaxation switch assay with functionalized Fe/Fe3O4 nanoparticles. Sens. Actuators B 2014, 203, 477-482. [CrossRef]

194. Li, N.; Liu, T.; Liu, S.G.; Lin, S.M.; Fan, Y.Z.; Luo, H.Q.; Li, N.B. Visible and fluorescent detection of melamine in raw milk with one-step synthesized silver nanoparticles using carbon dots as the reductant and stabilizer. Sens. Actuators B 2017, 248, 597-604. [CrossRef]

195. Miao, P.; Han, K.; Sun, H.; Yin, J.; Zhao, J.; Wang, B.; Tang, Y. Melamine functionalized silvern as the probe for electrochemical sensing of clenbuterol. ACS Appl. Mater. Interfaces 2014, 6, 8667-8672. [CrossRef] [PubMed]

196. Li, X.-Z.; Yu, R.; Wei, X.-W. Template-based in situ fabrication and melamine sensing of bis(8-quinolinolato)zinc(II) complex nanorod arrays. Chem. Lett. 2010, 39, 114-115. [CrossRef]

197. Chen, L.; Luo, L.; Chen, Z.; Zhang, M.; Zapien, J.A.; Lee, C.S.; Lee, S.T. ZnO/Au composite nanoarrays as aubstrates for surface-enhanced Raman scattering detection. J. Phys. Chem. C 2010, 114, 93-100. [CrossRef]

198. Chen, L.-M.; Liu, Y.-N. Ag-nanoparticle-modified single Ag nanowire for detection of melamine by surface-enhanced Raman spectroscopy. J. Raman Spectrosc. 2012, 43, 986-991. [CrossRef]

199. Xu, F.; Zhang, Y.; Sun, Y.; Shi, Y.; Wen, Z.; Li, Z. Silver nanoparticles coated zinc oxide nanorods array as superhydrophobic substrate for the amplified SERS effect. J. Phys. Chem. C 2011, 115, 9977-9983. [CrossRef]

200. Li, J.; Kuang, D.; Feng, Y.; Zhang, F.; Xu, Z.; Liu, M. A novel electrochemical method for sensitive detection of melamine in infant formula and milk using ascorbic acid as recognition element. Bull. Korean Chem. Soc. 2012, 33, 2499. [CrossRef]

201. Zhao, T.; Liu, L.; Li, G.; Dang, A.; Li, T. Electrochemical determination of melamine with a glassy carbon electrode coated with a multi-wall carbon nanotube/chitosan composite. J. Electrochem. Soc. 2012, 159, K141-K145. [CrossRef]

202. Peng, B.; Li, G.; Li, D.; Dodson, S.; Zhang, Q.; Zhang, J.; Lee, Y.H.; Demir, H.V.; Ling, X.Y.; Xiong, Q. Vertically aligned gold nanorod monolayer on arbitrary substrates: Self-assembly and femtomolar detection of food contaminants. ACS Nano 2013, 7, 5993-6000. [CrossRef] [PubMed]

203. Chen, L.; Chabu, J.M.; Jin, R.; Xiao, J. Single gold-nanoparticles-decorated silver/carbon nanowires as substrates for surface-enhanced Raman scattering detection. RSC Adv. 2013, 3, 26102-26109. [CrossRef]

204. Sivashanmugan, K.; Liao, J.-D.; Liu, B.H.; Yao, C.-K. Focused-ion-beam-fabricated Au nanorods coupled with Ag nanoparticles used as surface-enhanced Raman scattering-active substrate for analyzing trace melamine constituents in solution. Anal. Chim. Acta 2013, 800, 56-64. [CrossRef] [PubMed]

205. Shi, Y.-E.; Li, L.; Yang, M.; Jiang, X.; Zhao, Q.; Zhan, J. A disordered silver nanowires membrane for extraction and surface-enhanced Raman spectroscopy detection. Analyst 2014, 139, 2525-2530. [CrossRef] [PubMed]

206. Dai, Z.; Mei, F.; Xiao, X.; Liao, L.; Fu, L.; Wang, J.; Wu, W.; Guo, S.; Zhao, X.; Li, W.; et al. "Rings of saturn-like" nanoarrays with high number density of hot spots for surface-enhanced Raman scattering. Appl. Phys. Lett. 2014, 105, 033515. [CrossRef]

207. Chen, L.; Jiang, D.; Liu, X.; Qiu, G. $\mathrm{ZnGa}_{2} \mathrm{O}_{4}$ nanorod arrays decorated with Ag nanoparticles as surface-enhanced Raman-scattering substrates for melamine detection. ChemPhysChem 2014, 15, 1624-1631. [CrossRef]

208. Sivashanmugan, K.; Liao, J.-D.; Liu, B.H.; Yu, L.C. AuGa 2 on focused Ga ion beam fabricated Au nanorod array for trace detection of melamine cyanurate in milk solution. Appl. Phys. Exp. 2015, 8, 017001. [CrossRef]

209. Chen, X.; Lian, S.; Ma, Y.; Peng, A.; Tian, X.; Huang, Z.; Chen, X. Electrochemiluminescence sensor for melamine based on a $\left[\mathrm{Ru}(\mathrm{bpy})_{3}\right]^{2+}$-doped silica nanoparticles/carboxylic acid functionalized multi-walled carbon nanotubes/Nafion composite film modified electrode. Talanta 2016, 146, 844-850. [CrossRef]

210. Cheng, J.; Su, X.-O.; Yao, Y.; Han, C.; Wang, S.; Zhao, Y. Highly sensitive detection of melamine using a one-step sample treatment combined with a portable Ag nanostructure array SERS sensor. PLoS ONE 2016, 11, e0154402. [CrossRef]

211. Kara, S.A.; Keffous, A.; Giovannozzi, A.M.; Rossi, A.M.; Cara, E.; D’Ortenzi, L.; Sparnacci, K.; Boarino, L.; Gabouze, N.; Soukane, S. Fabrication of flexible silicon nanowires by self-assembled metal assisted chemical etching for surface enhanced Raman spectroscopy. RSC Adv. 2016, 6, 93649-93659. [CrossRef]

212. Yola, M.L.; Eren, T.; Atar, N. A Molecular imprinted voltammetric sensor based on carbon nitride nanotubes: Application to determination of melamine. J. Electrochem. Soc. 2016, 163, B588-B593. [CrossRef] 
213. Liang, X.; Zhang, X.-J.; You, T.-T.; Wang, G.-S.; Yin, P.-G.; Guo, L. Controlled assembly of one-dimensional MoO3@Au hybrid nanostructures as SERS substrates for sensitive melamine detection. CrystEngComm 2016, 18, 7805-7813. [CrossRef]

214. Cook, A.L.; Carson, C.S.; Marvinney, C.E.; Giorgio, T.D.; Mu, R.R. Sensing trace levels of molecular species in solution via zinc oxide nanoprobe Raman spectroscopy. J. Raman Spectrosc. 2017, 48, 1116-1121. [CrossRef]

215. Roy, A.; Sahoo, R.; Chowdhury, J.; Bhattacharya, T.S.; Agarwal, R.; Pal, T. Directional growth of Ag nanorod from polymeric silver cyanide: A potential substrate for concentration dependent SERS signal enhancement leading to melamine detection. Spectrochim. Acta A 2017, 183, 402-407. [CrossRef] [PubMed]

216. Gao, Y.; Yang, N.; You, T.; Zhang, C.; Yin, P. Superhydrophobic "wash free" 3D nanoneedle array for rapid, recyclable and sensitive SERS sensing in real environment. Sens. Actuators B 2018, 267, 129-135. [CrossRef]

217. Huang, J.; Chen, F.; Zhang, Q.; Zhan, Y.; Ma, D.; Xu, K.; Zhao, Y. 3D silver nanoparticles decorated zinc oxide/silicon heterostructured nanomace arrays as high performance surface-enhanced Raman scattering substrates. ACS Appl. Mater. Interfaces 2015, 7, 5725-5735. [CrossRef]

218. Rajkumar, K.; Jayram, N.D.; Mangalaraj, D.; Rajendra Kumar, R.T. One step 'dip' and 'use' Ag nanostructured thin films for ultrahigh sensitive SERS Detection. Mater. Sci. Eng. C 2016, 68, 831-836. [CrossRef]

219. Zhang, J.; Qu, S.; Zhang, L.; Tang, A.; Wang, Z. Quantitative surface enhanced Raman scattering detection based on the "sandwich" structure substrate. Spectrochim. Acta A 2011, 79, 625-630. [CrossRef]

220. Rahman, M.M.; Ahmed, J. Cd-doped $\mathrm{Sb}_{2} \mathrm{O}_{4}$ nanostructures modified glassy carbon electrode for efficient detection of melamine by electrochemical approach. Biosens. Bioelectron. 2018, 102, 631-636. [CrossRef]

221. Soomro, R.A.; Hallam, K.R.; Ibupoto, Z.H.; Tahira, A.; Jawaid, S.; Hussain Sherazi, S.T.; Sirajjuddin; Willander, M. A highly selective and sensitive electrochemical determination of melamine based on succinic acid functionalized copper oxide nanostructures. RSC Adv. 2015, 5, 105090-105097. [CrossRef]

222. Guo, Z.; Cheng, Z.; Li, R.; Chen, L.; Lv, H.; Zhao, B.; Choo, J. One-step detection of melamine in milk by hollow gold chip based on surface-enhanced Raman scattering. Talanta 2014, 122, 80-84. [CrossRef] [PubMed]

223. Jean, R.-D.; Chiu, K.-C.; Chen, T.-H.; Chen, C.-H.; Liu, D.-M. Functionalized silica nanoparticles by nanometallic Ag decoration for optical sensing of organic molecule. J. Phys. Chem. C 2010, 114, 15633-15639. [CrossRef]

224. Zhao, Y.; Luo, W.; Kanda, P.; Cheng, H.; Chen, Y.; Wang, S.; Huan, S. Silver deposited polystyrene (PS) microspheres for surface-enhanced Raman spectroscopic-encoding and rapid label-free detection of melamine in milk powder. Talanta 2013, 113, 7-13. [CrossRef] [PubMed]

225. Mekonnen, M.L.; Su, W.-N.; Chen, C.-H.; Hwang, B.-J. Ag@SiO 2 nanocube loaded miniaturized filter paper as a hybrid flexible plasmonic SERS substrate for trace melamine detection. Anal. Methods 2017, 9, 6823-6829. [CrossRef]

226. Li, J.-M.; Yang, Y.; Qin, D. Hollow nanocubes made of Ag-Au alloys for SERS detection with sensitivity of $10^{-8} \mathrm{M}$ for melamine. J. Mater. Chem. C 2014, 2, 9934-9940. [CrossRef]

227. Chen, L.; Wu, M.; Xiao, C.; Yu, Y.; Liu, X.; Qiu, G. Urchin-like $\mathrm{LaVO}_{4} / \mathrm{Au}$ composite microspheres for surface-enhanced Raman scattering detection. J. Colloid Interface Sci. 2015, 443, 80-87. [CrossRef]

228. Chen, L.; Huang, Y.; Xing, T.T.; Ge, L.; Yang, T.; Chen, B.; Huang, C.Z. A portable multi-channel sensing device using Au nano-urchins as probes for melamine detection in milk. J. Mater. Chem. C 2017, 5, 7806-7812. [CrossRef]

229. Nguyen, T.H.; Nguyen, T.D.; Ly, N.H.; Kwak, C.H.; Huh, Y.S.; Joo, S.-W. On-site detection of sub-mg/kg melamine mixed in powdered infant formula and chocolate using sharp-edged gold nanostar substrates. Food Addit. Contam. A 2018, 35, 1017-1026. [CrossRef]

230. He, L.; Shi, J.; Sun, X.; Lin, M.; Yu, P.; Li, H. Gold coated zinc oxide nanonecklaces as a SERS substrate. J. Nanosci. Nanotechnol. 2011, 11, 3509-3515. [CrossRef]

231. Nieuwoudt, M.K.; Martin, J.W.; Oosterbeek, R.N.; Novikova, N.I.; Wang, X.; Malmström, J.; Williams, D.E.; Simpson, M.C. Gold-sputtered Blu-ray discs: Simple and inexpensive SERS substrates for sensitive detection of melamine. Anal. Bioanal. Chem. 2016, 408, 4403-4411. [CrossRef] [PubMed]

232. Cao, Q.; Yuan, K.; Yu, J.; Delaunay, J.-J.; Che, R. Ultrafast self-assembly of silver nanostructures on carbon-coated copper grids for surface-enhanced Raman scattering detection of trace melamine. J. Colloid Interface Sci. 2017, 490, 23-28. [CrossRef] 
233. Roy, B.; Bairi, P.; Nandi, A.K. Supramolecular assembly of melamine and its derivatives: Nanostructures to functional materials. RSC Adv. 2014, 4, 1708-1734. [CrossRef]

234. Zhang, J.; Ou, C.; Shi, Y.; Wang, L.; Chen, M.; Yang, Z. Visualized detection of melamine in milk by supramolecular hydrogelations. Chem. Commun. 2014, 50, 12873-12876. [CrossRef]

235. Bhosale, R.S.; Al Kobaisi, M.; Bhosale, S.V.; Bhargava, S.; Bhosale, S.V. Flower-like supramolecular self-assembly of phosphonic acid appended naphthalene diimide and melamine. Sci. Rep. 2015, 5, 14609. [CrossRef] [PubMed]

236. Kumari, R.; Banerjee, S.S.; Bhowmick, A.K.; Das, P. DNA-melamine hybrid molecules: From self-assembly to nanostructures. Beilstein J. Nanotechnol. 2015, 6, 1432-1438. [CrossRef] [PubMed]

237. De Acha, N.; Elosua, C.; Matias, I.; Arregui, F. Luminescence-based optical sensors fabricated by means of the layer-by-layer nano-assembly technique. Sensors 2017, 17, 2826. [CrossRef] [PubMed]

238. Gao, A.; Li, Y.; Lv, H.; Liu, D.; Zhao, N.; Ding, Q.; Cao, X. Melamine tunable effect in a lenalidomide-based supramolecular self-assembly system via hydrogen bonding. New J. Chem. 2017, 41, 7924-7931. [CrossRef]

239. Bhosale, R.S.; La, D.D.; Al Kobaisi, M.; Bhosale, S.V.; Bhosale, S.V. Melamine and spermine mediated supramolecular self-assembly of octaphosphonate tetraphenyl porphyrin. ChemistrySelect 2017, 2, 1573-1577. [CrossRef]

240. Shellaiah, M.; Sun, K. Luminescent metal nanoclusters for potential chemosensor applications. Chemosensors 2017, 5, 36. [CrossRef]

(C) 2019 by the authors. Licensee MDPI, Basel, Switzerland. This article is an open access article distributed under the terms and conditions of the Creative Commons Attribution (CC BY) license (http:/ / creativecommons.org/licenses/by/4.0/). 